Bull. Mater. Sci., Vol. 19, No. 2, April 1996, pp. 201-265. Printed in India.

\title{
Beneficiation of tungsten ores in India: A review
}

\author{
N KRISHNA RAO \\ Ore Dressing Section, Bhabha Atomic Research Centre, Begumpet, Hyderabad 500016, India
}

\begin{abstract}
Tungsten is a strategic metal for India, and almost the entire requirement is met by imports. Extensive search for tungsten in recent years has led to the discovery of several deposits. However, almost all these are of low grade compared to world resources. Technoeconomic exploitation of these deposits depends to a great extent on the development of suitable beneficiation technology within the framework of an ore-to-product integrated approach. This paper presents a review of the current research and development status of beneficiation technology applicable to these deposits.

The deposits covered are: (i) Degana, comprising of four distinct types, namely, quartz vein, eluvial, phyllite and granite, (ii) Balda, (iii) Khobna-Kuhi-Agargoan, (iv) BurugubandaTapaskonda, (v) Scheelite-bearing gold ores of Kolar and Hutti, and (vi) Madurai. Investigations on these ores have been mainly carried out by BARC, IBM, BRGM (France), NML and RRL (Bhubaneswar). While studies of BARC have been described in detail, those of the other laboratories are briefly discussed. Emphasis has been laid on discussing the industrial flow-sheets recommended during these investigations.

The strategy needed for the techno-economic feasibility of beneficiation of low grade tungsten ores are (i) effective pre-concentration at as coarse a size as possible, (ii) emphasis on higher recovery rather than on high grade of the concentrate, (iii) a two-product approach, one of high grade feasible by physical beneficiation methods and the other of low grade, to be upgraded by chemical methods to directly usable products, thus maximizing recovery, and (iv) a maximum utilization concept, aiming to recover all possible byproducts. The flow-sheets developed for the beneficiation of individual deposits are discussed in the light of the above strategy.
\end{abstract}

Keywords. Tungsten ores of India; beneficiation flow-sheets; international practice; preconcentration; upgradation; economic level of concentration; by-product recovery; ore to product strategy.

\section{Introduction}

The special properties of tungsten and its alloys such as extreme hardness, wear resistance, high melting point, high density and low vapour pressure have made it one of the most sought after and unique metals. It finds applications in a number of industries, including defence and high technology fields, for which no other substitutes have so far been found. It is one of the strategic metals identified for stockpiling in many countries. Its critical use in several defence applications, a meagre indigenous production, and total dependency on imports with consequent drain in the foreign exchange, have made tungsten one of the strategic metals in India. As against the present demand of about 2500 tonnes per year, which is expected to reach about 4500 tonnes by the turn of the century, the indigenous production of tungsten is a meagre 20-30 tonnes per year (Anon 1991).

\section{Geochemistry and mineralogy}

Tungsten may be considered as one of the rarer elements in the earths crust, the average crustal abundance is estimated to be at 1 to $1.3 \mathrm{ppm}$. The highest content among 
Table 1. Various tungsten deposits and their locations.

\begin{tabular}{|c|c|}
\hline Type of deposit & Major locations \\
\hline Skarn & $\begin{array}{l}\text { Primorskii Krai (Vostok II), Central Asia } \\
\text { (Ingichke, Koitash), Caucasus (Turnyaz) all in } \\
\text { USSR., Sang-Dong (South Korea), Khuan-Podi } \\
\text { (China), Emerald Feney (Canada), Pine Creek } \\
\text { (USA) and King Island (Australia) }\end{array}$ \\
\hline Greisen & $\begin{array}{l}\text { Transbaikal Region (Spokoininskii) Kazhakstan } \\
\text { (Akchatau, Kara-Oba) in USSR., Sadisdorf, } \\
\text { Pechdelgrun (GDR), Montebrasse (France), } \\
\text { Pyaton, Sinkiangshang (China), Wolfram Camp, } \\
\text { Terrangton (Australia) }\end{array}$ \\
\hline $\begin{array}{l}\text { Plutonogenic } \\
\text { hydrothermal }\end{array}$ & $\begin{array}{l}\text { Chukotka (Iultin), Transbaikal Region (Bukuka), } \\
\text { Kazhakstan (Upper Kairakty) in USSR., } \\
\text { Panas-Queira (Portugal), Cornwall (UK), Belfort } \\
\text { (France), Red-Rose (Canada), Herberton (Australia) }\end{array}$ \\
\hline $\begin{array}{l}\text { Volcanogenic } \\
\text { hydrothermal }\end{array}$ & $\begin{array}{l}\text { Transbaikal Region (Barun-Shiveya) Central Asia } \\
\text { (Tasor, lkar), Cacausus (Zopki-to) in USSR., Usin, } \\
\text { Siang (China), Akenobe (Japan), Tungoten-Queen } \\
\text { (Canada), Yellow-Boulder, Atolia (USA), Ascension } \\
\text { (Bolivia), Hillgrow (Australia) }\end{array}$ \\
\hline Placers & $\begin{array}{l}\text { Magaden Area (Iultin), Transbaikal Region (Serl } \\
\text { Mountain), Kazhakstan (Kara-Oba) in USSR., } \\
\text { Atolia (USA), Bvabin, Heida (Burma) and also in } \\
\text { China, Indonesia, Thailand, Congo and Bolivia }\end{array}$ \\
\hline
\end{tabular}

igneous rocks is in granites, particularly $S$ and $A$ types. Sedimentary rocks on an average contain 1 to $2 \mathrm{ppm}$ tungsten.

Wolframite group of minerals and scheelite are the main source of tungsten. Ferberite $\left(\mathrm{FeWO}_{4}\right)$ and huebnerite $\left(\mathrm{MnWO}_{4}\right)$ form an isomorphous series, with wolframite being the intermediate member. Scheelite $\left(\mathrm{CaWO}_{4}\right)$ often contains appreciable amounts of molybdenum either as isomorphous substitution or in the form of powellite $\left[\mathrm{Ca}(\mathrm{MoW}) \mathrm{O}_{4}\right]$. Cuprotungstite $\left(\mathrm{CuWO}_{4}\right)$, cuproscheelite $\left[(\mathrm{CaCu}) \mathrm{WO}_{4}\right]$, and stolzite $\left(\mathrm{PbWO}_{4}\right)$ are some of the uncommon tungsten minerals, while tungstite $\left(\mathrm{WO}_{3}\right)$, ferritungstite $\left(\mathrm{Fe}_{2} \mathrm{O}_{3} \cdot \mathrm{WO}_{3} \cdot 6 \mathrm{H}_{2} \mathrm{O}\right)$, anthoinite $\left[\mathrm{Al}\left(\mathrm{WO}_{4}\right)(\mathrm{OH}) \mathrm{H}_{2} \mathrm{O}\right]$ and mpororite are some of the secondary minerals.

\section{Tungsten deposits}

Both endogenous and exogenous tungsten deposits occur, the former types, however, dominate. Endogenous types are classified into four types according to Russian geologists, namely (i) skarn, (ii) greisen, (iii) plutonogenic hydrothermal (or granite related) and (iv) volcanogenic hydrothermal. Exogenous deposits are mainly represented by placer concentrations. Granite-related deposits occur in four main inter gradational genetic types, viz. magmatic disseminations, pegmatites, porphyries and veins, and are typically associated with a host of other characteristic metals like Sn, Mo, $\mathrm{Ta}, \mathrm{Bi}$ etc. Table 1 gives some of the major world occurrences of these principle types of tungsten deposits (Anon 1988; Padmanabhan et al 1990). 


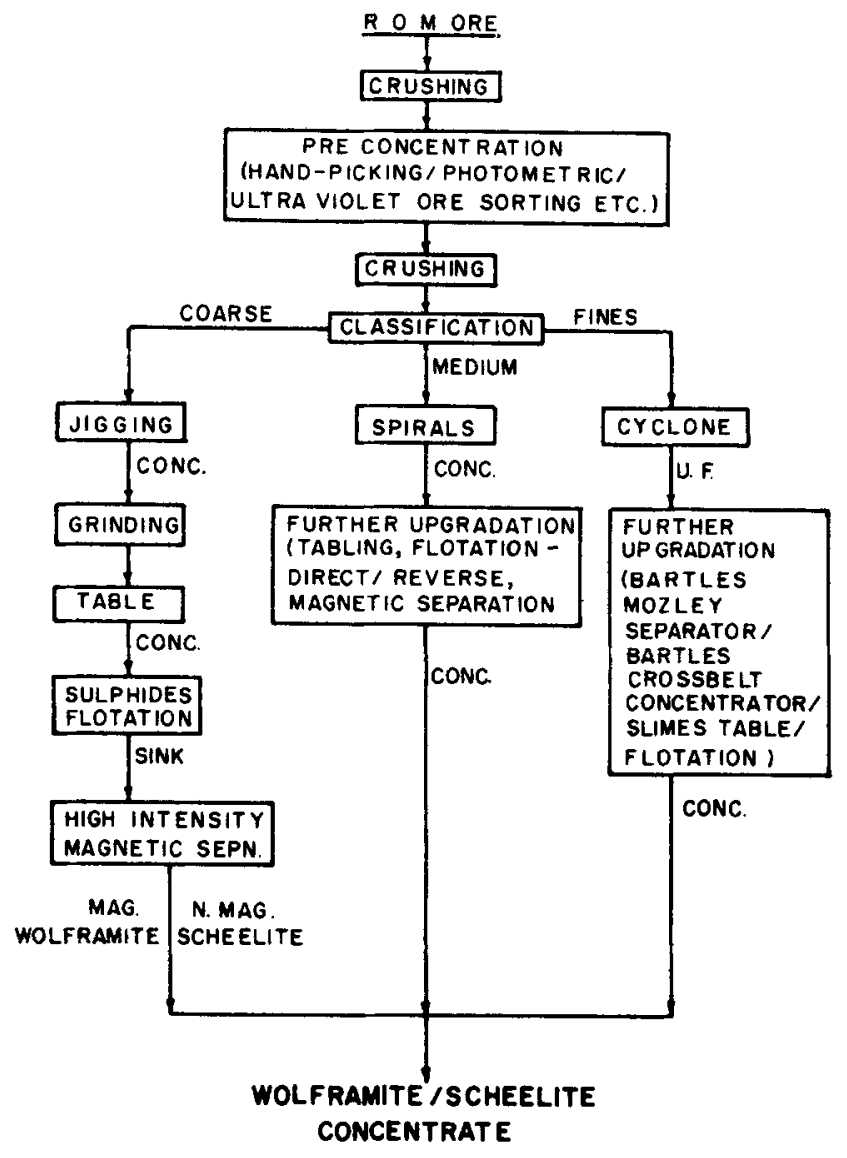

Figure 1. Generalized flow-sheet for the beneficiation of tungsten ores.

\section{Processing of tungsten ores: International practice}

Most of the tungsten ores exploited world over have grades of $>0.5 \% \mathrm{WO}_{3}$. When lower grade ores are worked, the economics is linked to some by-product minerals. Tungsten ore deposits can consist of simple wolframite, simple scheelite or a wolframite-scheelite combination. The beneficiation flow-sheet followed largely depends on the nature of mineralization in the ore body, and the size of liberation of the tungsten minerals. However the beneficiation process generally consists of a pre-concentration step after crushing and grinding of the ROM ore, followed by processing the preconcentrate, concentrate cleaning or up-gradation step, and a final purification stage to meet the market specifications. A generalized flow-sheet (Padmanabhan et al 1990) generally followed for processing tungsten ores, is schematically shown in figure 1.

A variety of pre-concentration processes are employed to reject the bulk of barren and low grade waste prior to the main processing. Hand-sorting (Baldia et al 1984) is preferred for pre-concentration in many countries. Mechanical sorters based on the reflectivity differences between the minerals in the case of wolframite, and ultraviolet ore sorters in the case of fluorescent scheelite are extensively made use of (Anon 1979; Ermolenko et al 1985; Minonov et al 1987; Zhaboev et al 1987). However, gravity 
separation is the most common pre-concentration method in a very large number of tungsten ore processing plants (Borchers 1979; Ottley 1979). The high density of both scheelite and wolframite facilitates their easy separation by gravity techniques. Scalping jigs, shaking tables, spirals and Reichert cones are widely used for pre-concentration. Heavy media separation in cyclones, using ferrosilicon as the medium, is used in the plant at Panasqueira, Portugal. Magnetic separation techniques are also used for pre-concentration, both for scheelite (non-magnetic) and wolframite (strongly paramagnetic) bearing ores. For example, low intensity magnetic separation is employed in Uludag mine in Turkey for the removal of magnetite, and high intensity magnetic separation for the rejection of garnet and other paramagnetic gangue minerals (Karahan et al 1980). Although flotation or reverse flotation is commonly practiced in concentrate cleaning stages, its use in the pre-concentration stage is being increasingly advocated, especially in cases where gravity methods fail to give satisfactory results. Scheelite floats comparatively easily compared to wolframite and a number of scheelite producers use flotation to advantage (Mitchell et al 1951; Babok and Viduetskii 1967; Auge et al 1975; Vasquez et al 1976; Texeira et al 1988). A number of reagents have also been tried for the flotation of wolframite, and a comprehensive literature on this is available elsewhere (Rao 1991; TRDDC 1991). Specially designed separators as well as new technologies are being suggested in pre-concentration of fine-sized tungsten mineral particles, viz. centrifugal separators (Han and Say 1985), shear flocculation (Warren 1975a, b; Jarrett and Warren 1977; Shao and Shi 1986; Koh et al 1986; Rao G V 1987), spherical agglomeration (Dawei et al 1986; Kelsall and Pitt 1987), high gradient magnetic separation (Gak et al 1983; Sun Shanlun et al .1984; Svoboda 1988), etc.

Processing of the pre-concentrate is generally a multistage operation, involving size reduction for near complete liberation, classification, gravity separation, direct or reverse flotation, and magnetic and high tension separations (Padmanabhan et al 1990). Wolframite is paramagnetic and electrically conducting, hence high intensity magnetic separation and high tension separation would be able to upgrade it. Scheelite is both non-magnetic and non-conducting. Sulphide minerals are normally removed from the pre-concentrate by reverse flotation, wherein they are floated while the tungsten values remain in the flotation sink. Pyrrhotite has poor flotation response, but it can be removed by low intensity magnetic separation. If pyrite proves difficult for removal by flotation, the pre-concentrate containing pyrite can be roasted, which converts pyrite into a magnetic form, separable by magnetic separation. Tables, and vanners are also used for upgradation of tungsten mineral concentrates.

Tungsten beneficiation plants normally operate with a recovery of $60-85 \%$ (Padmanabhan et al 1990). Most of the losses of tungsten occur in slimes, which are not amenable for normal gravity separation methods. Generation of tungsten mineral slimes occurs due to two reasons. First, tungsten minerals being friable in nature, are highly susceptible to differential grinding, and consequently get ground preferentially during crushing and grinding. Secondly, because of the high density of tungsten minerals, they tend to go into over-size fraction during classification by cyclones or hydraulic type of classifiers used in the grinding circuit, and get recycled to the grinding mill, leading to their over-grinding. To reduce excessive generation of slimes multistage crushing and grinding are often employed. One of the fundamental practice followed in modern milling is to size the ore as it passes through the plant and recover as much of the metal values as possible from each size at each stage. In other words the strategy is 
to have size reduction and recovery in stages to meet the philosophy of "the earlier recovered, the more recovered" (Weisun 1982) and to avoid difficulty for treatment of slimes.

The market specifications for the concentrates demand a minimum grade of $65 \%$ and $70 \% \mathrm{WO}_{3}$ respectively for wolframite and scheelite concentrates, with stringent controls of sulphur, phosphorous and silica contents (Stafford 1985). However, in cases where marketable grade concentrates can not be achieved at reasonable recovery, a scheme of 'forward integration' is advocated (Borchers 1979). This scheme is slowly replacing the established system of separate centre of tungsten activity (viz. mining and ore dressing; metallurgical extraction; metal, carbide and ferro-tungsten production; fabrication, etc.). In situations where further upgrading of the low grade concentrate is constrained by increasing losses, the economic level concentrate produced is processed by the application of modern chemical extraction technology to achieve maximum recovery. A discussion on chemical beneficiation practices is beyond the scope of this review; however, a brief reference to the work carried out in India on this aspect is made at the end under 'General discussion'.

\section{The Indian scene}

The wide gap between demand and indigenous supply of tungsten raw materials, and the strategic status accorded to tungsten world over, a great emphasis has been placed in India on improving the tungsten resource base. A flurry of activities on exploration for new tungsten ore deposits, feasibility studies on the beneficiation of indigenous ore resources as well as extraction of metal, are in progress in many national laboratories and institutes. As a result of this intensive activity an in situ geological resource of nearly 30,000 tonnes of tungsten metal at a cut-off grade of $0 \cdot 1 \%$ have now been established (see table 2). The information contained in table 2 is called from various sources, mainly from the Proceedings of the National Workshop on Tungsten Resources Development held at Bhubaneswar in 1987.

The major ore deposits are located (Sehgal and Satyanarayana 1987) in Degana in Rajasthan, Khobna-Kuhi belt in Maharashtra and Burugubanda-Tapaskonda belt in Andhra Pradesh. A potential major deposit is in the Jaurasi-Koerali belt of Almora District in UP. Deposits of minor importance are those occurring in Balda, Deva Ka Bara and Pali in Rajasthan, Agargoan and Kolari-Bhaonri in Maharashtra, Bankura in West Bengal, Madurai in Tamilnadu, Attapadi in Kerala and Gadag in Karnataka. Besides, the gold ores of Kolar (Anon 1985) and Hutti (Raju et al 1987) in Karnataka contain significant concentrations of scheelite potentially recoverable as a by-product of gold.

However most of these deposits are in the low grade category, the tenor varying between 0.1 and $0.2 \% \mathrm{WO}_{3}$, as against the commonly exploited grade of $0.5 \%$ or more world over. The challenge therefore lies in establishing the feasibility of economic exploitation of these low grade resources. In order to achieve this goal, an 'ore to product' integrated approach (Rama Rao 1990) is called for, which visualizes an integrated strategy for the development of exploration, exploitation, extraction, production and utilization of the indigenous resources of strategic metals. Beneficiation forms an important and integral component of the exploitation strategy. In the case of tungsten, though resources have been established in the recent years, their exploitation 
Table 2. Major tungsten deposits in India.

\begin{tabular}{|c|c|c|c|c|c|}
\hline Locality & $\begin{array}{l}\text { Type of } \\
\text { deposit }\end{array}$ & W. mineral & $\begin{array}{l}\text { Tenor } \\
\text { range } \\
\mathrm{WO}_{3} \%\end{array}$ & $\begin{array}{l}\text { Resources } \\
\text { million } \\
\text { tonnes }\end{array}$ & $\begin{array}{c}\text { Contained } \\
\mathrm{WO}_{3} \\
\text { tonnes }\end{array}$ \\
\hline \multirow[t]{4}{*}{$\begin{array}{l}\text { 1. Degana } \\
\text { (Rajasthan) }\end{array}$} & $\begin{array}{l}\text { Quartz veins } \\
\text { in granite }\end{array}$ & Wolframite & $0.2-0.5$ & 25 & 425 \\
\hline & $\begin{array}{l}\text { Disseminations } \\
\text { in granite }\end{array}$ & Wolframite & $0.03-0.12$ & 168 & 134000 \\
\hline & $\begin{array}{l}\text { Stockwork in } \\
\text { phyllite }\end{array}$ & Wolframite & $0.01-0.05$ & $2 \cdot 70$ & 675 \\
\hline & Eluvial placer & Wolframite & $0.01-0.06$ & $3 \cdot 30$ & 1320 \\
\hline $\begin{array}{l}\text { 2. Balda } \\
\text { (Rajasthan) }\end{array}$ & $\begin{array}{l}\text { Greisenised } \\
\text { pegmatite \& } \\
\text { granite }\end{array}$ & Wolframite & $0.1-0.5$ & $0 \cdot 15$ & 370 \\
\hline $\begin{array}{l}\text { 3. Khobna-Kuhi } \\
\text { (Maharashtra) }\end{array}$ & Greisen \& vein & $\begin{array}{l}\text { Scheelite } \\
\text { Wolframite } \\
\text { (minor) }\end{array}$ & $0.15-0.4$ & $2 \cdot 73$ & 8190 \\
\hline $\begin{array}{l}\text { 4. Burugubanda- } \\
\text { Tapaskonda } \\
\text { (A.P.) }\end{array}$ & $\begin{array}{l}\text { Pegmatite } \\
\text { veins in } \\
\text { Khondalite }\end{array}$ & Wolframite & $0.1-0.16$ & $11 \cdot 0$ & 16500 \\
\hline \multirow{2}{*}{$\begin{array}{l}\text { 5. KGF } \\
\text { (Karnataka) }\end{array}$} & Tailing dumps & Scheelite & $0.04-0.2$ & 1.0 & 720 \\
\hline & $\begin{array}{l}\text { Gold-bearing } \\
\text { lodes }\end{array}$ & Scheelite & $0.07-0.2$ & 0.37 & 700 \\
\hline $\begin{array}{l}\text { 6. Hutti } \\
\text { (Karnataka) }\end{array}$ & $\begin{array}{l}\text { Gold-bearing } \\
\text { lodes }\end{array}$ & Scheelite & 0.08 & 1.08 & 850 \\
\hline $\begin{array}{l}\text { 7. Almora } \\
\text { (U. P.) }\end{array}$ & Skarn & Scheelite & $0.1-0.15$ & 30 & 3750 \\
\hline $\begin{array}{l}\text { 8. Kambalipatti- } \\
\text { Rayapatti } \\
\text { (Tamilnadu) }\end{array}$ & Skarn & Scheelite & $0 \cdot 1-0 \cdot 3$ & & \\
\hline 9. Bankura & Quartz veins & Wolframite & & & \\
\hline $\begin{array}{l}\text { 10. Deva-ka-Bara } \\
\text { (Rajasthan) }\end{array}$ & Skarns & Scheelite & $0-14-0.4$ & 0.06 & 130 \\
\hline $\begin{array}{l}\text { 11. Agargaon } \\
\text { (Maharashtra) }\end{array}$ & Quartz-veins & $\begin{array}{l}\text { Wolframite } \\
\text { Scheelite }\end{array}$ & $0.04-0-27$ & $2 \cdot 23$ & 1300 \\
\hline
\end{tabular}

have been held up due to non development of an techno-economically viable strategy for beneficiation. Considerable amount of research and developmental efforts in this direction have been continuing in several national laboratories. A review of these studies follows. Almost all of the potential tungsten ore deposits have been investigated at the Ore Dressing Section laboratory of Bhabha Atomic Research Centre, and these are covered in greater detail, while available information of the efforts at other laboratories are briefly discussed. Reports of the Strategic Minerals (Group XII) Sub-Committee of Geological Survey of India and of the BRGM (France) - MECL (India) Tin-Tungsten Collaborative Programme have also been extensively made use of in gathering the information on the beneficiation of Indian tungsten ores. Wherever possible reference to appropriate reports are made. 
The beneficiation characteristics of the following tungsten ores of the country are covered in this review: (i) Degana, (ii) Balda, (iii) Khobna, (iv) Burugubanda-Tapaskonda, (v) Kolar and Hutti and (vi) Madurai.

\section{Wolframite ore from Degana, Rajasthan}

Degana is the only tungsten mine in the country where mining and production of wolframite concentrate, albeit in minor quantities, has been continuing from the year 1916 (Bansal et al 1987). The Degana deposit consists of three small hills near Rewat village $5 \mathrm{~km}$ west of Degana Railway Station in the Nagaur District of Rajasthan. Here the older phyllites of the Delhi Super Group are intruded by the Degana Granite. Wolframite-bearing quartz veins have intruded the granites as well as the older phyllites. While the quartz veins are the main carriers of wolframite, both the granite and part of the phyllite contain disseminated wolframite brought in by the impregnating siliceous solutions. On the slopes of the hills also occur wolframite bearing eluvial gravel bed, derived by the weathering of the granite. The gravel bed is consolidated by calcareous impregnations.

Five types of resources of wolframite in the Degana area are identified. These are (i) quartz vein type, (ii) the granite type, (iii) the phyllite type, (iv) the eluvial type and (v) the tailing and waste dumps of the earlier workings. Two categories of granite-type are recognized, a Trench lode granite which forms the broad zone of the granite encompassing the quartz veins, and the granite as a whole. The average grades and estimated resources in the different type of deposits (Bansal et al 1987; Patni et al 1987; Sehgal and Satyanarayana 1987; Anon 1988) are included in table 2, and their mineralogical composition (of representative samples investigated in BARC) in table 3.

\subsection{Quartz vein type ore}

The Ore Dressing Section, BARC has investigated in detail (Padmanabhan et al 1984, 1985) the beneficiation characteristics of a representative ore sample of the quartz vein

Table 3. Mineralogical composition of tungsten ores of Degana (Ore samples investigated in BARC) (All in \%).

\begin{tabular}{|c|c|c|c|c|c|}
\hline & \multicolumn{2}{|c|}{ Eluvial } & \multirow[b]{2}{*}{ Granite } & \multirow[b]{2}{*}{$\begin{array}{l}\text { Quartz } \\
\text { vein }\end{array}$} & \multirow[b]{2}{*}{ Phyllite } \\
\hline & $\begin{array}{l}\text { Sample } 1 \\
\text { (Siliceous) }\end{array}$ & $\begin{array}{c}\text { Sample } 2 \\
\text { (Calcareous) }\end{array}$ & & & \\
\hline Quartz and felspar & 77 & 51 & $62 \cdot 5$ & 76 & 85 \\
\hline $\begin{array}{l}\text { Calcite and calca- } \\
\text { reous cement }\end{array}$ & 15 & 38 & & & \\
\hline Topaz & 4 & 6 & $13 \cdot 5$ & 9 & 7 \\
\hline Mica & 3 & $3 \cdot 5$ & $23 \cdot 4$ & 11 & 3 \\
\hline $\begin{array}{l}\text { Other transparent } \\
\text { minerals }\end{array}$ & 0.5 & $0 \cdot 5$ & 0.2 & 1 & 0.5 \\
\hline $\begin{array}{l}\text { Opaque minerals } \\
\text { (Incl. Wolframite) }\end{array}$ & 0.5 & $1 \cdot 0$ & 0.4 & 3 & $2 \cdot 5$ \\
\hline Assay $\mathrm{WO}_{3}$ & 0.04 & $0 \cdot 023$ & 0.04 & $0 \cdot 26$ & 0.013 \\
\hline
\end{tabular}




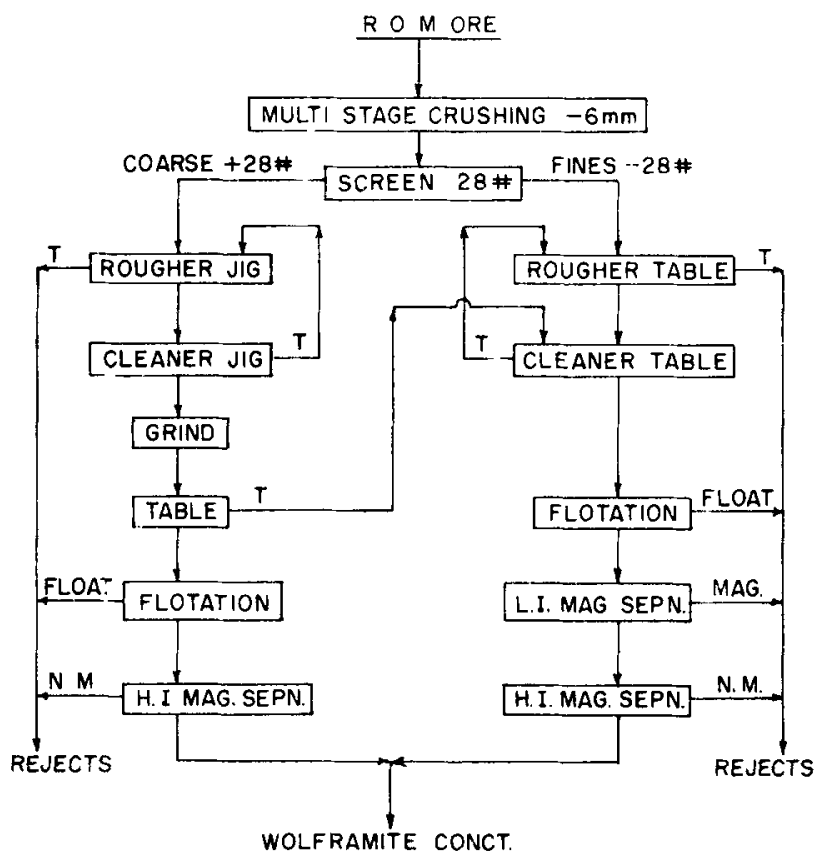

Figure 2. BARC flow-sheet (schematic) for the beneficiation of quartz vein type tungsten ore from Degana.

type made available by the then RSTDC, of average assay $0 \cdot 27 \% \mathrm{WO}_{3}$ in the form of wolframite (with huebnerite: ferberite ratio being about 1 ). Quartz (76\%), muscovitezinnwaldite mica $(11 \%)$ and topaz $(9 \%)$ were the major minerals in the ore. Ore minerals identified, besides wolframite are, pyrrhotite, pyrite, chalcopyrite, ilmenite, magnetite, hematite, cassiterite, bismuthinite and native bismuth. Minor fluorite and trace monazite and zircon are also present. A trimodal grain size distribution of wolframite is observed: (i) coarse crystals of 2 to $8 \mathrm{~mm}$ size, (ii) medium sized grains or aggregates of platy crystals of size 50 to $250 \mu \mathrm{m}$, and (iii) very fine skeletal crystals of 10 to $25 \mu \mathrm{m}$ size, generally occurring as inclusions within mica. The first two categories account for nearly $90 \%$ of tungsten distribution.

While developing a flow-sheet to beneficiate this ore the following aspects were kept in mind: (i) a substantial part of the tungsten values occur in sizes coarser than $2 \mathrm{~mm}$, (ii) fine/crushing grinding of the ore to near complete liberation of wolframite at one stretch would lead to excessive wolframite slime generation, which is undesirable, and (iii) it is advisable to reject bulk of barren material at a relatively coarse size to reduce cost of grinding.

The flow-sheet developed to process the ore (Padmanabhan et al 1984) is schematically shown in figure 2 . The ROM ore is stage crushed to all passing through $6 \mathrm{~mm}$ screen, and classified into two streams on a 28 \# screen. The coarse stream is processed by two stage jigging, and the cleaner jig concentrate is further concentrated by tabling after grinding to all passing through 28 \#. Sulphide minerals from the table concentrate are removed by flotation, followed by high intensity magnetic separation of the flotation sink, which gives a magnetic wolframite concentrate. The original screen undersize is processed by tabling followed by flotation and magnetic separation as 
Table 4. Summary of results of semi pilot plant scale test on quartz-vein type ore (Flow-sheet given in figure 2).

\begin{tabular}{|c|c|c|c|c|}
\hline & Product & Weight $\%$ & $\mathrm{WO}_{3}$ Assay $\%$ & $\mathrm{WO}_{3}$ Dist. $\%$ \\
\hline \multicolumn{2}{|l|}{ Feed } & $100 \cdot 0$ & $0 \cdot 264$ & $100 \cdot 0$ \\
\hline$+28 \#$ & Coarse Feed & $80 \cdot 7$ & $0 \cdot 25$ & 76.6 \\
\hline$-28 \#$ & Fine Feed & $19 \cdot 3$ & $0 \cdot 32$ & $23 \cdot 4$ \\
\hline$+28 \#$ & Cleaner Jig Conct. & 1.6 & $9 \cdot 40$ & $57 \cdot 0$ \\
\hline$+28 \#$ & Cleaner Jig Tails & $15 \cdot 4$ & $0 \cdot 13$ & $7 \cdot 6$ \\
\hline$+28 \#$ & Rougher Jig Tails & $63 \cdot 7$ & 0.05 & $12 \cdot 0$ \\
\hline$+28 \#$ & Table Conct. & $0 \cdot 23$ & $55 \cdot 60$ & $48 \cdot 5$ \\
\hline$+28 \#$ & Table Tails & $1 \cdot 37$ & 1.64 & $8 \cdot 5$ \\
\hline$+28 \#$ & Sulphide Float & 0.03 & $2 \cdot 50$ & $0 \cdot 3$ \\
\hline$+28 \#$ & Nonmag. Fraction & 0.01 & $5 \cdot 10$ & 0.2 \\
\hline+28 & Magnetic Wolframite Conct. & $0 \cdot 19$ & $66 \cdot 60$ & $48 \cdot 0$ \\
\hline$-28 \#$ & Table Conct. & $0 \cdot 50$ & $9 \cdot 20$ & $17 \cdot 4$ \\
\hline$-28 \#$ & Table Tails & $18 \cdot 8$ & $0 \cdot 084$ & 6.0 \\
\hline$-28 \#$ & Sulphide Float & $0 \cdot 20$ & $0 \cdot 60$ & $0 \cdot 5$ \\
\hline$-28 \#$ & LIMS Magnetics & 0.05 & $1 \cdot 50$ & $0 \cdot 3$ \\
\hline$-28 \#$ & HIMS Nonmagnetics & $0 \cdot 18$ & $1 \cdot 10$ & $0 \cdot 7$ \\
\hline$-28 \#$ & HIMS Magnetics (Wolframite) & 0.07 & $60 \cdot 00$ & $15 \cdot 9$ \\
\hline \multicolumn{2}{|c|}{ Combined Wolframite Conct. } & $0 \cdot 26$ & $64 \cdot 80$ & $63 \cdot 9$ \\
\hline
\end{tabular}

above. In a semi pilot plant scale test this flow-sheet gave a final combined wolframite concentrate of $64.8 \% \mathrm{WO}_{3}$ at a recovery of $64 \%$. Material balance obtained in the laboratory test is given in table 4 .

In industrial scale the rougher jig tails can be subjected to a stage of grinding and processed by spiralling followed by tabling of the spiral pre-concentrate, in order to improve the overall recovery. Overall a recovery of $+65 \%$ in a $+65 \% \mathrm{WO}_{3}$ grade concentrate is confidently expected by following this flow-sheet.

After detailed laboratory studies in the laboratory of Atomic Minerals Division, Dwivedy (1988) suggested three different flow-sheets for the beneficiation of the quartz vein type ore. Of the three, flow-sheet 1 is nearly identical to the BARC flow-sheet, which gave a final wolframite concentrate assaying $66 \% \mathrm{WO}_{3}$ at a recovery of $62 \%$. The other two flow-sheets envisage grinding the ore to all passing through $35 \#$, followed by pre-concentration either by gravity methods or by wet high intensity magnetic separation. Final concentrating steps are reverse flotation and magnetic separation as in the BARC flow-sheet. However these flow-sheets are only suggested flow-sheets, and have been tested up to the pre-concentration stage only. One of these suggests pre-concentration by WHIMS after size reduction to $-35 \#$, and in the laboratory test a recovery of $72.6 \%$ in the WHIMS pre-concentrate at a grade of $16.9 \%$ $\mathrm{WO}_{3}$ could be achieved.

Indian Bureau of Mines (IBM) have also conducted tests on quartz vein type ore sample (Datta 1987) following more or less the flow-sheet developed by BARC. Initially, a concentrate assaying $53 \% \mathrm{WO}_{3}$ could be obtained at an overall recovery of $35.5 \%$ only. Later, however, some modifications were tried and the results obtained were said to be better than BARC results. In these tests, while the basic flow-sheet of BARC was retained, the particle sizes for treatment at different stages were changed. 


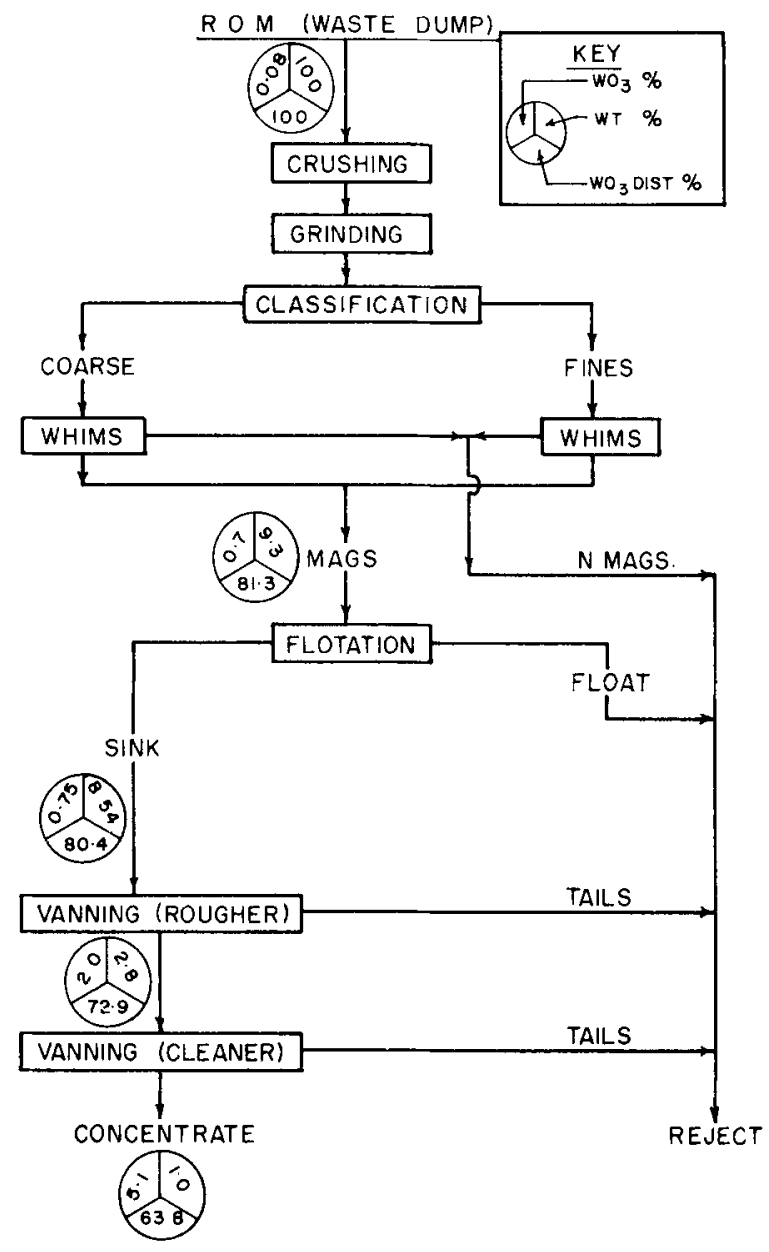

Figure 3. Flow-sheet (schematic) followed by NML for the recovery of wolframite from waste dump from Degana, along with metallurgical material balance at important preconcentration stages.

A pilot plant test following a flow-sheet consisting of spiralling, tabling, reverse flotation and magnetic separation has reported an overall recovery of $68 \%$ at a grade of $68 \cdot 5 \%$ (Sehgal and Satyanarayana 1987 ), an excellent result indeed!

\subsection{Waste dumps}

During mining and processing of quartz-vein lode type ore over the years, the rejects after manual hand picking and dry processing were accumulated in the form of waste dumps. These dumps are also considered to be important resource for tungsten as it analyses on an average $0 \cdot 1 \% \mathrm{WO}_{3}$. Both NML (1992) and IBM (Rao G M 1993) have studied in detail the recovery of wolframite from the waste dumps. Granulometric analysis of a representative waste dump sample by NML has shown that there is no preferential concentration of tungsten values in any of the size fractions and hence 
rejection by screening of any size fraction is out of question. The major findings of the NML study are:

(i) Grinding to an optimum size is essential for liberation, and overgrinding needs to be avoided to reduce loss of wolframite values in slimes.

(ii) WHIMS has been found to be very effective method for pre-concentration and produces a clean tail with the rejection of about $90 \%$ of mass of feed.

(iii) Classification before WHIMS and processing the coarse and fines streams separately improves efficiency of separation in WHIMS.

(iv) A two-stage flotation of sulphides, one in acidic circuit and the other in alkaline circuit is necessary to remove the sulphides effectively.

(v) It would be advisable to aim at an economic level of concentration of 5-20\% $\mathrm{WO}_{3}$ followed by chemical beneficiation, for optimum economic recovery.

The flow-sheet worked out by NML for the processing of waste dump ore is schematically shown in figure 3 . The final recovery will depend on the grade of the pre-concentrate; at $5 \% \mathrm{WO}_{3}$ a recovery of $>60 \%$ could be acheived, and at $30 \% \mathrm{WO}_{3}$ the recovery falls to about $46 \%$. Rao (1993) reports results of tests carried out by IBM on two waste dump samples, analysing 0.14 and $0.15 \% \mathrm{WO}_{3}$. From the first sample, by a process involving tabling, flotation, magnetic separation and separation in Mozley mineral separator, a final concentrate of $66.50 \% \mathrm{WO}_{3}$ at $59.8 \%$ recovery was obtained, while from the second sample the final concentrate assayed $66 \cdot 3 \% \mathrm{WO}_{3}$ by a process involving tabling. flotation and retabling. The results are excellent indeed compared to what was achieved in the NML study, however the latter sample assayed only $0.08 \%$ $\mathrm{WO}_{3}$ and for liberation a much finer grind was necessary.

\subsection{Eluvial gracel}

The eluvial tungsten ore from Degana is perhaps the most extensively tested among the different types of ore from Degana. Investigations have been carried out by National Metallurgical Laboratory (NML), BARC. Regional Research Laboratory, Bhubaneswar (RRL-B), IBM and by the Golder Moffit Associates (GMA) of UK. The overall average grade of the eluvial gravel bed is estimated to be 0.02 to $0.04 \% \mathrm{WO}_{3}$ (Patni et al $1987)$, even though some of the samples from the gravel bed tested assayed as high as $0.11 \% \mathrm{WO}_{3}$ (Datta 1987).

During the early fifties NML investigated the feasibility of beneficiation of a sample of the eluvial gravel analyzing $0.11 \% \mathrm{WO}_{3}$ (Banerjee and Narayanan 1952). By a combination of screening, jigging, tabling and magnetic separation a product analyzing $56.6 \% \mathrm{WO}_{3}$ with $57 \cdot 7 \%$ distribution was obtained. Alternatively tabling followed by magnetic separation after size reduction to all passing through $35 \#$ produced a concentrate assaying $66 \cdot 3 \% \mathrm{WO}_{3}$ with $48.8 \%$ distribution. NML also studied another sample analyzing $0.052 \% \mathrm{WO}_{3}$ during the early seventies (Kunwar et al 1972). While tabling and magnetic separation at 48 \# size yielded a concentrate assaying $13.6 \% \mathrm{WO}_{3}$ with $60 \%$ recovery, a complicated flow-sheet involving a combination of hydraulic classification, tabling, high tension separation, reduction roast followed by magnetic separation with $48 \#$ feed, produced a concentrate assaying $36.0 \% \mathrm{WO}_{3}$ with $50 \%$ recovery.

BARC carried out the tests during the early seventies. Two ore samples, with differing mineralogical composition, one with high siliceous gangue and the other with 


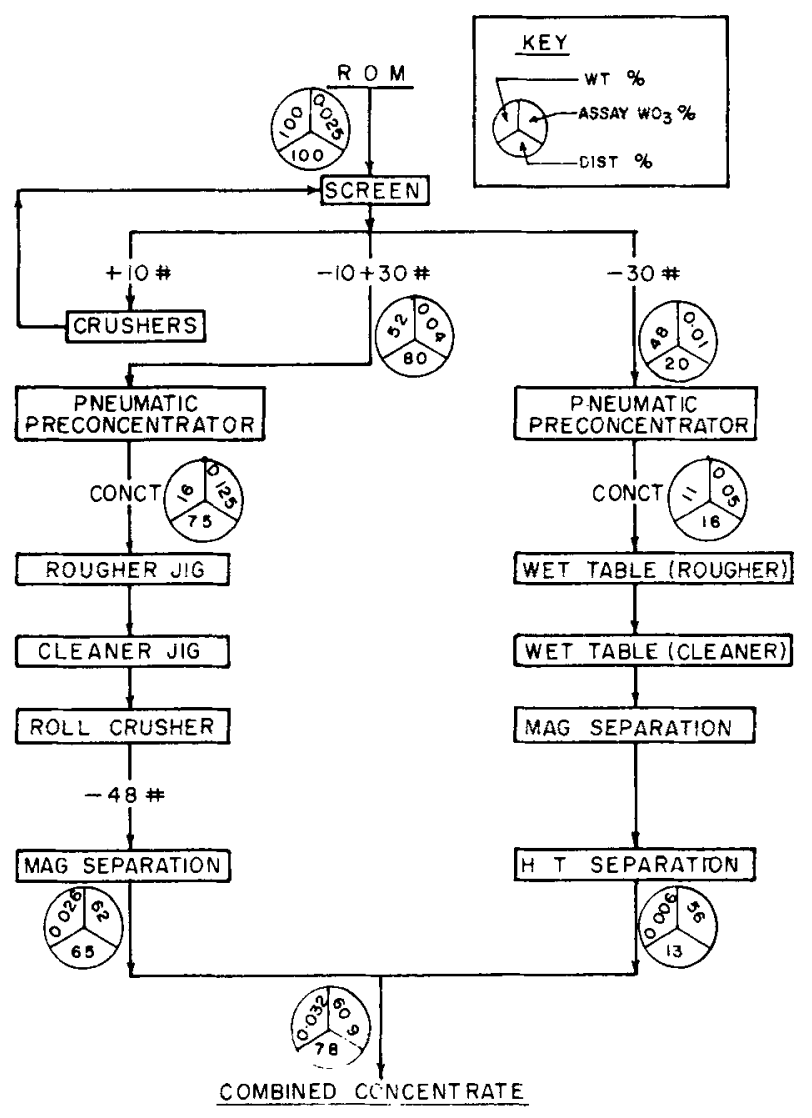

Figure 4. Flow-sheet for the recovery of wolframite from the eluvial ore (calcareous matrix) from Degana, with metallurgical material balance.

appreciable calcareous gangue were investigated (Ghosh et al 1968; Narasimham et al 1972). These analyzed $0.04 \%$ and $0.023 \% \mathrm{WO}_{3}$ respectively. Mineralogical composition of representative samples of the two types are included in table 3.

An important feature of the flow-sheet developed is the rejection of bulk of the gangue minerals during the pre-concentration stage by the use of a dry pneumatic device designed and fabricated in-house. The ore after being reduced in stages to all passing through 10 mesh screen, is classified into two fractions, $+30 \#$ and $-30 \#$. Both the fractions pre-concentrated in the pneumatic device. The coarser pre-concentrate is processed on jigs in two stages and the cleaner jig concentrate was upgraded by magnetic separation, after grinding to all passing through about 65\#. The finer pre-concentrate was cleaned on wet shaking tables, and further upgraded by magnetic separation, followed by high tension separation. This flow-sheet, schematically shown in figure 4 , is followed in the case of the calcareous type of ore sample. From a feed grade of $0.023 \% \mathrm{WO}_{3}$ a final concentrate assaying $61 \% \mathrm{WO}_{3}$ could be obtained at nearly $80 \%$ recovery. The high recovery was possible due to the fact that in the eluvial ore wolframite occurs in a near liberated state, and that during size reduction to all passing through $10 \#$ in this 'calcareous'-cemented sample further sliming of the brittle wolframite does not take place. 


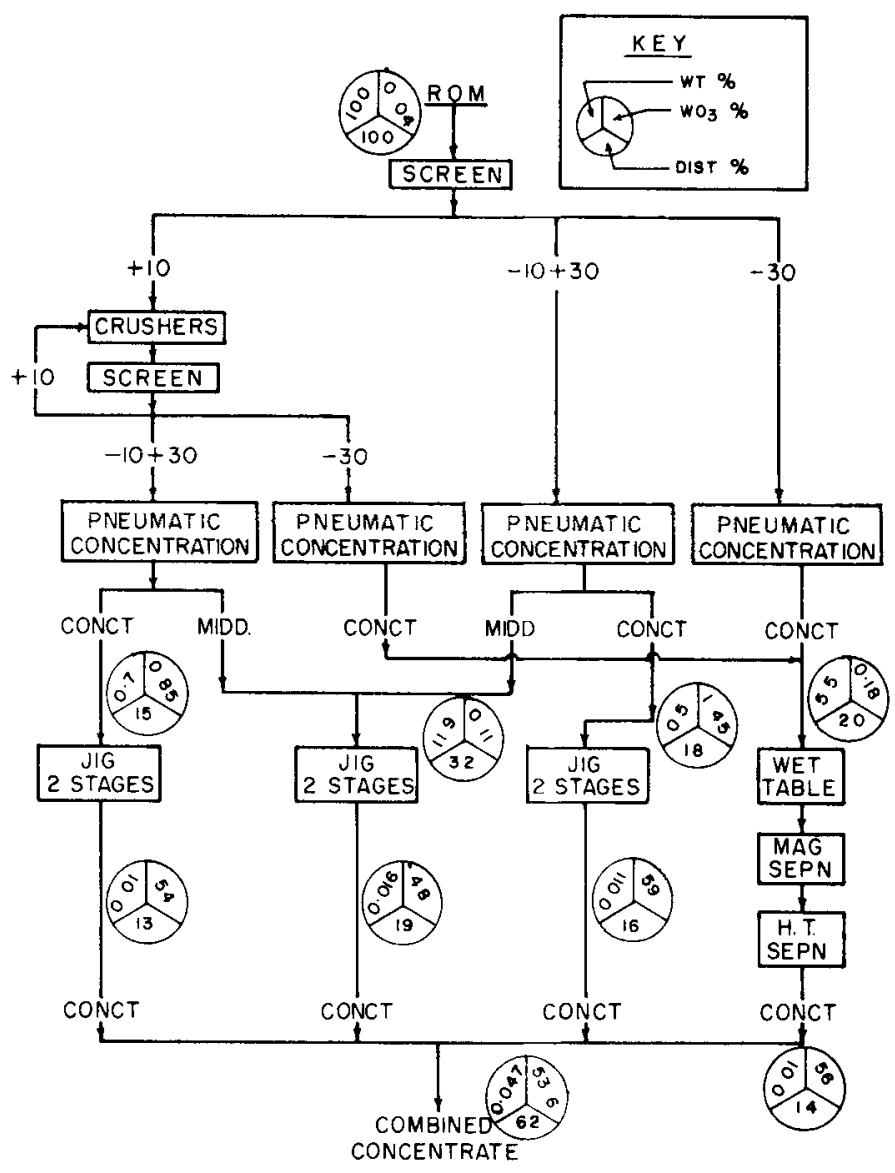

Figure 5. Flow-sheet for the recovery of wolframite from the eluvial ore (siliceous matrix) from Degana, with metallurgical material balance.

The 'siliceous' ore sample was, on the other hand, more complex. Firstly the -10 $+30 \#$ and -30 \# fractions in the ROM differed in mineralogy and other characteristics from similar size fractions obtained after crushing the ROM coarser sizes, and hence had to be processed separately. Secondly the hard nature of the silica cemented ore necessitated considerable crushing to reduce the ore to all passing through $10 \#$, and this resulted in generation of considerable slimy wolframite affecting its recovery. The flow-sheet adopted to process this type of the ore is schematically shown in figure 5 . Overall a recovery of only $62 \%$ could be achieved at $53 \% \mathrm{WO}_{3}$ grade. The study has also shown that cassiterite and monazite are the potential byproducts of processing the eluvial ore. Both these minerals are concentrated during pre-concentration by gravity methods and are separated from wolframite only during final magnetic and high tension separation stages.

The investigations clearly showed that (i) processing should be done at the coarsest size possible compatible with the grain size of wolframite, so as to avoid sliming of brittle wolframite, (ii) some sort of pre-concentration, preferably in a dry process, at a relatively coarse size, is necessary not only to make the subsequent concentration 
process more efficient, but also to make the beneficiation process economically viable, and (iii) the grade of the deposit varies considerably and in order to develop an industrial flow-sheet a proper blending of the ROM ore is essential.

The bench scale work carried out by M/s Golder Moffit Associates of U.K. in the early eighties, at the request of Mineral Development Board, confirmed the need for pre-concentration at a relatively coarse size, and desirability of desliming before treatment. However their test work produced a pre-concentrate assaying $5 \cdot 4 \% \mathrm{WO}_{3}$ and $0.4 \% \mathrm{Sn}$ at recoveries of $54.6 \%$ and $43.3 \%$ respectively (Lahiri and Patni 1988).

Subsequently Regional Research Laboratory, Bhubaneswar took up further work on the lines suggested by Golder Associates. These studies (Narasimhan K S 1988) have shown the feasibility of application of dry magnetic separation for the pre-concentration of wolframite, after size reduction of the ore to $-2 \mathrm{~mm}$ size. The finding was substantiated through bulk processing of 8 tonnes of the gravel sample using disc type high intensity dry magnetic separation at 1.2 Tesla magnetic field intensity. From a sample of feed grade $0.02 \% \mathrm{WO}_{3}$, a pre-concentrate assaying $0.4 \% \mathrm{WO}_{3}$ at an estimated recovery of $60 \%$ was achieved. According to Narasimhan (1988) the separation at magnetic intensity of 1.6 Tesla magnetic intensity can improve the recovery. A test carried out by $\mathrm{M} / \mathrm{s}$ CARPCO by two-stage magnetic separation using induced rolls and lift type magnetic separators, and reported by Narasimhan (1988), gave nearly $86 \%$ recovery at a grade of $1 \% \mathrm{WO}_{3}$, though the feed grade of the sample tested was high, at $0 \cdot 18 \% \mathrm{WO}_{3}$. The pre-concentrate obtained from the eluvials is expected to be amenable to further enrichment in the same way as the wolframitebearing quartz vein type of ore.

\subsection{Phyllite type ore}

Two samples of the so called phyllite ore, made available by Rajasthan State Tungsten Development Corporation, were studied by BARC (Shukla et al 1985). Essentially the samples were micaceous quartzites affected by pneumatolytic alteration, and assayed $0.013 \%$ and $0.022 \% \mathrm{WO}_{3}$. Mineralogically both the samples were similar, analyzing, quartz $85 \%$, mica $3 \%$, topaz $7 \%$, and opaque minerals including iron oxides $3 \%$. Liberation analysis indicated that over $60 \%$ of tungsten values were liberated at a grind of $80 \%$ passing through 65 \#. Ore samples ground to about $50 \%$ passing through 200 \# were hydraulically classified into three fractions, each of which were processed on wet shaking tables in two stages, separately. Sulphides from the cleaner table concentrates were floated, and the flotation sink subjected to magnetic separation in a laboratory WHIMS. The final concentrates assayed 11 to $13 \% \mathrm{WO}_{3}$ at overall recoveries of 45 to $48 \%$, in the two samples. The results are summarized in table 5 .

\subsection{Granite type ore}

Exploration work undertaken by Rajasthan State Tungsten Development Corporation followed by geostatistical analysis during mid eighties have indicated that the granite has been mineralized more or less uniformly, and that the average tenor is about $0.08 \% \mathrm{WO}_{3}$ in a total of 169 million tonnes of ore (Patni et al 1987). Notwithstanding its low tenor, exploitation of the granite presents a challenge in view of the shear vastness of the deposit. Studies have been carried out both at Indian Bureau of Mines 
Table 5. Results of beneficiation of phyllite type ore from Degana.

\begin{tabular}{|c|c|c|c|c|}
\hline & Expt. 1 & Expt. 2 & Expt. 3 & Expt. 5 \\
\hline Feed Assay $\left(\mathrm{WO}_{3} \%\right)$ & $0 \cdot 013$ & 0.013 & $0 \cdot 013$ & $0 \cdot 013$ \\
\hline \multicolumn{5}{|l|}{ Tabling Stage } \\
\hline Concentrate $\mathrm{W}_{1} . \%$ & 0.82 & $3 \cdot 58$ & $5 \cdot 13$ & $1 \cdot 37$ \\
\hline Concentrate Grade $\left(\mathrm{WO}_{3} \%\right)$ & 0.85 & 0.24 & 0.19 & 0.57 \\
\hline Overall Recovery $\%$ & 54 & 66 & 76 & 60 \\
\hline \multicolumn{5}{|l|}{ Sulphide Flotation Stage } \\
\hline Concentrate Wt. $\%$ & & & $4 \cdot 61$ & $1 \cdot 21$ \\
\hline Concentrate Grade $\left(\mathrm{WO}_{3} \%\right)$ & & & $0 \cdot 20$ & 0.63 \\
\hline Overall Recovery $\%$ & & & 71 & 58.8 \\
\hline \multicolumn{5}{|l|}{ Cleaner Tabling Stage } \\
\hline Concentrate Wt. $\%$ & & & & $0 \cdot 215$ \\
\hline Concentrate Grade ( $\left.\mathrm{WO}_{3} \%\right)$ & & & & $3 \cdot 26$ \\
\hline Overall Recovery $\%$ & & & & 54 \\
\hline \multicolumn{5}{|l|}{ Magnetic Separation Stage } \\
\hline Concentrate Wt. $\%$ & & $0 \cdot 381$ & $0 \cdot 341$ & 0.057 \\
\hline Concentrate Grade $\left(\mathrm{WO}_{3} \%\right)$ & & $2 \cdot 15$ & $2 \cdot 15$ & 11 \\
\hline Overall Recovery \% & & 63 & 56 & 48 \\
\hline
\end{tabular}

and at BARC on the feasibility of beneficiation of this type of the ore. While the ore samples tested by IBM assayed 0.08 to $0.09 \% \mathrm{WO}_{3}$, the bulk samples sent by RSTDC to BARC for testing analyzed 0.035 to $0.05 \% \mathrm{WO}_{3}$ only.

The Degana granite ore consists of pink, buff, grey and dark coloured varieties of coarse to medium-grained granite and fine-grained aplite. Mesocratic types grade into highly siliceous leucocratic varieties. All the varieties show extensive greisenization. Mineralogically orthoclase, microperthite, sodic plagioclase and quartz are the essential minerals. Muscovite mica, biotite and topaz are the main accessory constituents. Most of the muscovite appear to be the zinnwaldite variety. Due to greissenization some of the felspar and quartz have been replaced by topaz and zinnwaldite. Minor fluorite, tourmaline and calcite are also observed. Most of muscovite shows violet tinge in thicker flakes, and are often studded with pleochroic haloes around monazite and zircon inclusions.

Wolframite occurs in the form of medium to very fine sized subhedral to anhedral grains (varying in size from 150 to below $10 \mu \mathrm{m}$ ), introduced along minute fractures, grain boundaries and rain interstices of felsic minerals and cleavage planes of mica and topaz. Other opaque minerals observed are magnetite, ilmenite, pyrite, pyrrhotite and trace chalcopyrite. Typical mineralogical composition of a sample of the ore investigated by BARC (Shukla et al 1988) is given in table 3 .

\subsection{IBM test results}

Three samples of the granitic type of ore from different parts of the Degana granite body, with a feed grade varying between 0.07 to $0.09 \% \mathrm{WO}_{3}$ have been studied by IBM (Rao and Satyanarayana 1987). The main process adopted for the tests is identical, size reduction to all passing through $65 \#$, classification and tabling, flotation of combined table concentrate to remove sulphides, followed by magnetic separation of the flotation 
Table 6. Summary of IBM test results on granite type ore.

\begin{tabular}{|c|c|c|c|}
\hline Product & Weight $\%$ & $\mathrm{WO}_{3}$ Assay $\%$ & WO $_{3}$ Dist. $\%$ \\
\hline Test No. 1: Initial Grind - $65 \#$ & \multicolumn{2}{|c|}{ (Feed Assay $0.087 \%$ ) } & \\
\hline Combined Table Concentrate & $1 \cdot 10$ & 4.02 & $50 \cdot 44$ \\
\hline Magnetic Concentrate & 0.06 & $53 \cdot 01$ & $37 \cdot 50$ \\
\hline Test No. 2: Initial Grind $-65 \#$ & \multicolumn{2}{|c|}{ (Feed Assay $0.071 \%$ ) } & \\
\hline Combined Table Concentrate & $0 \cdot 80$ & $3 \cdot 83$ & 42.66 \\
\hline Magnetic Concentrate & 0.053 & $40 \cdot 14$ & $31 \cdot 12$ \\
\hline Mozley Concentrate & 0.026 & $59 \cdot 04$ & $23 \cdot 24$ \\
\hline Mozley Tailings & $0 \cdot 027$ & $19 \cdot 26$ & 7.88 \\
\hline Test No. 3: Initial Grind - 35\# & \multicolumn{2}{|c|}{ (Feed Assay 0.097\%) } & \\
\hline Combined Table Concentrate & $1 \cdot 50$ & 3.95 & $61 \cdot 87$ \\
\hline Magnetic Concentrate & 0.119 & 43.99 & $54 \cdot 95$ \\
\hline Test No. 4: Initial Grind $-35 \#$ & \multicolumn{2}{|c|}{ (Feed Assay $0.084 \%)$} & \\
\hline Spiral Pre-concentrate & $44 \cdot 18$ & $0 \cdot 164$ & $80 \cdot 46$ \\
\hline Combined Table Concentrate & 0.64 & $8 \cdot 35$ & $63 \cdot 3$ \\
\hline Magnetic Concentrate & 0.081 & $57 \cdot 35$ & 56.46 \\
\hline Mozley Concentrate & 0.054 & $65 \cdot 60$ & $43 \cdot 05$ \\
\hline Mozley Tails & 0.027 & $40 \cdot 85$ & 13.41 \\
\hline Test No. 5: Initial Grind - 65\# & \multicolumn{2}{|c|}{ (Feed Assay $0.084 \%$ ) } & \\
\hline Final Magnetic Concentrate & 0.081 & $58 \cdot 38$ & $58 \cdot 67$ \\
\hline Mozley Concentrate & 0.063 & $64 \cdot 64$ & 48.67 \\
\hline Mozley Tails & 0.019 & $36 \cdot 12$ & $7 \cdot 80$ \\
\hline
\end{tabular}

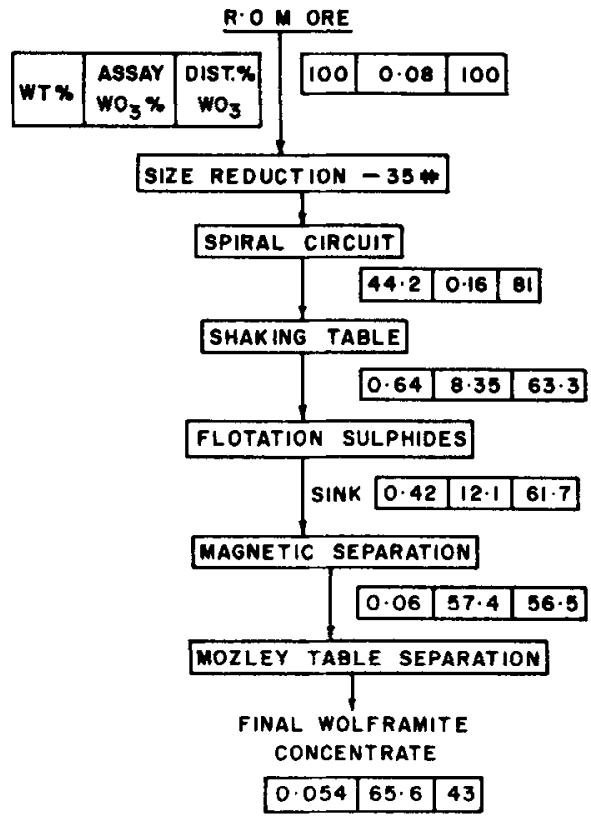

Figure 6. IBM flow-sheet for the beneficiation of the Degana granite-type ore, with metallurgical material balance. 
Table 7. Summary of BARC test results on granite type Degana ore (Feed Grade 0.04\% $\mathrm{WO}_{3}$ ).

\begin{tabular}{|c|c|c|c|c|c|c|}
\hline \multirow[b]{2}{*}{$\begin{array}{l}\text { Test } \\
\text { No. }\end{array}$} & \multirow[b]{2}{*}{ Initial grind } & \multirow[b]{2}{*}{ Major process steps } & \multicolumn{2}{|c|}{ Gravity conet } & \multicolumn{2}{|c|}{ Final conct } \\
\hline & & & $\begin{array}{l}\text { Grade } \\
\mathrm{WO}_{3} \%\end{array}$ & $\begin{array}{l}\text { Dist. } \\
\text { WO }_{3} \%\end{array}$ & $\begin{array}{l}\text { Grade } \\
\mathrm{WO}_{3} \%\end{array}$ & $\begin{array}{l}\text { Dist. } \\
\text { WO }_{3} \%\end{array}$ \\
\hline 1 & $\begin{array}{l}30 \% \text { passing } \\
\text { through } 200 \#\end{array}$ & $\begin{array}{l}\text { Hydraulic classification, } \\
\text { tabling in two stages, } \\
\text { cleaner table conc. } \\
\text { upgraded in WHIMS }\end{array}$ & 0.81 & $36 \cdot 5$ & $4 \cdot 1$ & $35 \cdot 2$ \\
\hline 2 & $\begin{array}{l}\text { The coarse and mediu } \\
\text { hydraulic classificatio } \\
\text { processed as above }\end{array}$ & $\mathrm{m}$ fractions of & 6.63 & $46 \cdot 4$ & $21 \cdot 0$ & $42 \cdot 0$ \\
\hline 3 & Similar to Test No. 2 & & 6.57 & $45 \cdot 2$ & $18 \cdot 6$ & $44 \cdot 1$ \\
\hline 4 & $\begin{array}{l}90 \% \text { passing } \\
\text { through } 150 \#\end{array}$ & $\begin{array}{l}\text { Bartles Vanner in } \\
\text { three stages }\end{array}$ & $2 \cdot 12$ & $39 \cdot 0$ & - & - \\
\hline 5 & $\begin{array}{l}90 \% \text { passing } \\
\text { through } 150 \#\end{array}$ & $\begin{array}{l}\text { Pre-conct. in WHIMS, } \\
\text { fotation of mica from } \\
\text { mags., tabling of flotation } \\
\text { sink, followed by final } \\
\text { upgradation in WHIMS }\end{array}$ & $9 \cdot 60$ & $35-8$ & $16 \cdot 7$ & $35 \cdot 8$ \\
\hline 6 & $\begin{array}{l}90 \% \text { passing } \\
\text { through } 150 \#\end{array}$ & $\begin{array}{c}\text { Processed as above, } \\
\text { flotation sink processed } \\
\text { in vanner in two stages } \\
\text { simulating BMS and } \\
\text { CBC (Flow-sheet in } \\
\text { figure 7) }\end{array}$ & $13 \cdot 0$ & $45 \cdot 0$ & $21 \cdot 2$ & $44 \cdot 0$ \\
\hline 7 & $\begin{array}{l}90 \% \text { passing } \\
\text { through } 150 \#\end{array}$ & $\begin{array}{l}\text { Flotation of mica, } \\
\text { followed by tabling of } \\
\text { flotation sink, final } \\
\text { up-gradation by WHIMS } \\
\text { (Flow-sheet in figure 8) }\end{array}$ & $10 \cdot 0$ & $44 \cdot 0$ & $22 \cdot 1$ & $43 \cdot 7$ \\
\hline
\end{tabular}

sink. The feebly magnetic fraction is further upgraded by separation on Mozley Laboratory Mineral Separator. The final results obtained in the different experiments are tabulated in table 6 . The sample no. 3 is also tested by the route of pre-concentration by spiralling followed by tabling of the spiral pre-concentrate. The flow-sheet followed is schematically given in figure 6. Samples reduced in size to all passing through 65 \# gave marginally superior result compared to the sample reduced to $35 \#$. The former resulted in a final concentrate assaying $64.4 \% \mathrm{WO}_{3}$ grade at a recovery of $48.7 \%$ while the latter resulted in a grade of $65 \cdot 6 \%$ at a recovery of $43.0 \%$.

\subsection{BARC test results}

Detailed studies were carried out on two samples of granite ore made available by RSTDC. Both the samples were identical in their characteristics, and replicate analysis gave the head assay as $0.04 \pm 0.003 \% \mathrm{WO}_{3}$. The sample also assayed $0.23 \% \mathrm{Li}_{2} \mathrm{O}$, with lithium occurring in the form of zinnwaldite. Liberation study indicated that for 


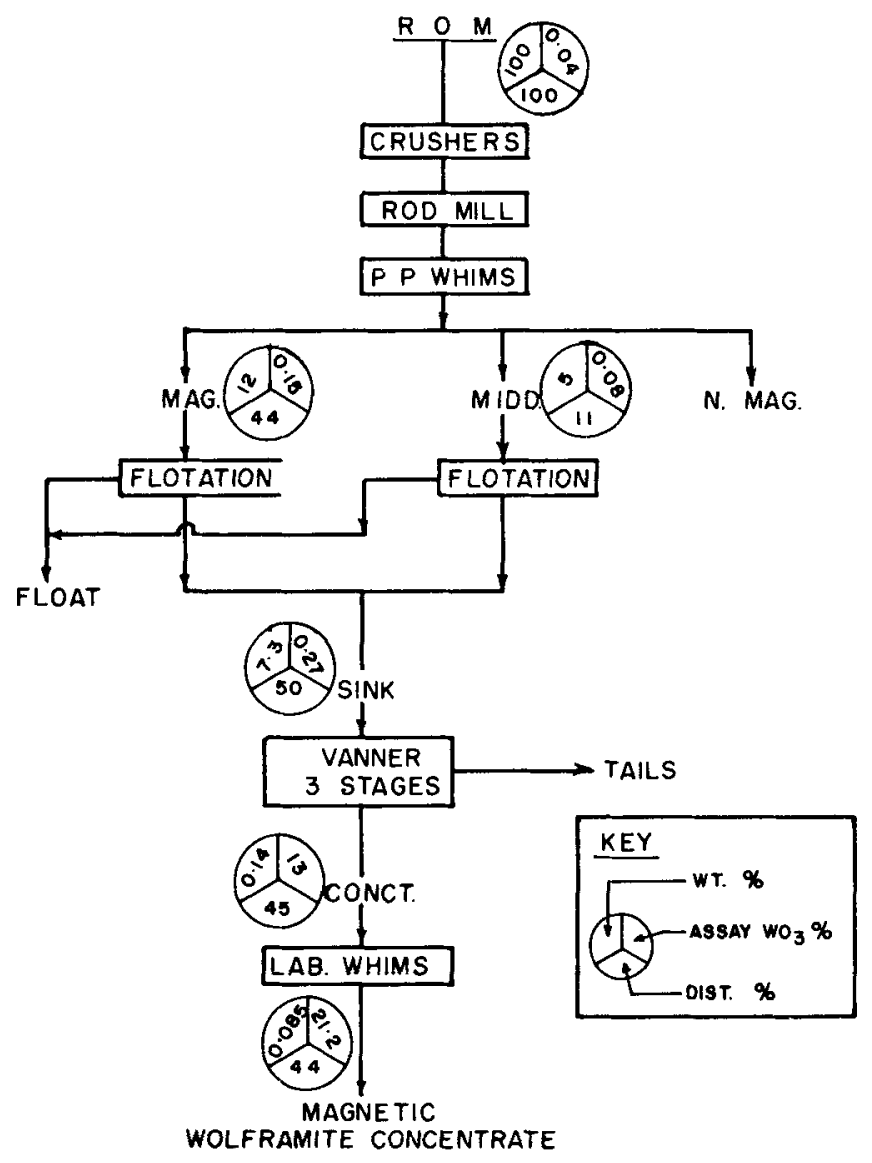

Figure 7. Flowchart of BARC Test 1 for the recovery of wolframite from the Degana granite-type ore, with metallurgical material balance.

optimum liberation of wolframite, the ore needs to be ground to all passing through $150 \#(100 \mu \mathrm{m})$, which will liberate about $80-85 \%$ of the tungsten values in the ore (Shukla et al 1988).

Batch beneficiation tests using shaking tables with slime deck, followed by magnetic separation, gave $35-45 \%$ recovery of tungsten at a grade of about $20 \% \mathrm{WO}_{3}$ (Shukla et al 1988). Pre-concentration before subjecting to tabling was attempted on Bartles machines (Bartles Mozley Separator and Bartles Cross Belt Concentrator), and by wet high intensity magnetic separator. The latter gave superior results. Summary of results obtained in different schemes of tests are given in table 7. Results of two tests following alternate schemes of upgradation of the WHIMS pre-concentrate are schematically depicted in figures 7 and 8 .

Based on a number of tests, an industrial flow-sheet is suggested (Shukla et al 1988). The flow-sheet schematically shown in figure 9 involves pre-concentration by WHIMS, followed by flotation of mica and gravity beneficiation of flotation sink. Since the ore needs fine grinding for optimum liberation, gravity beneficiation using Bartles Mozley Separator and Cross Belt Concentrator are suggested. Final upgradation is achieved by xanthate flotation of sulphides followed by magnetic separation. A final 


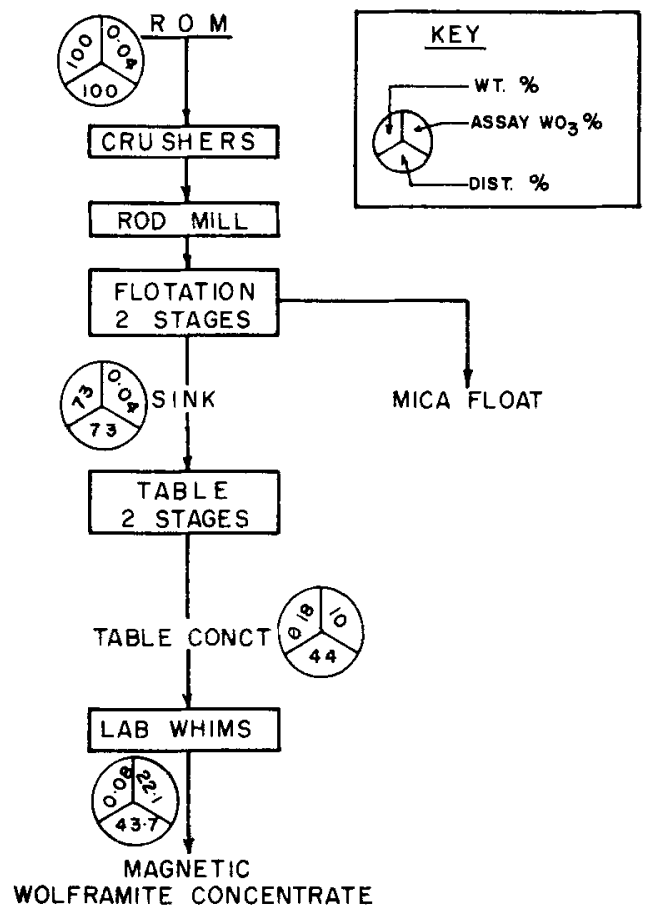

Figure 8. Flowchart of BARC Test 2 for the recovery of wolframite from the Degana granite-type ore, with metallurgical material balance.

concentrate assaying $30-35 \% \mathrm{WO}_{3}$ at an overall recovery of $40-45 \%$ starting from a feed of tenor 0.04 to $0.05 \% \mathrm{WO}_{3}$ is expected. The highlight of the flow-sheet is a lithiferous mica product assaying 0.8 to $0.9 \% \mathrm{Li}_{2} \mathrm{O}$, which can be upgraded to $>1 \%$ $\mathrm{Li}_{2} \mathrm{O}$. Another potential byproduct is a high grade topaz concentrate, Expected material balance is also indicated in the figure 9 .

\subsection{Discussion}

With the exploitation of the meagre resources of quartz-vein type ore by underground mining becoming uneconomical, the future of Degana prospect depends on harnessing the vast granite-type ore. Notwithstanding the very low tenor of the ore samples tested by BARC, two distinct flow-sheets have been developed and tested-one by IBM, and the other by BARC. In addition NML is also carrying out exhaustive studies on the beneficiation of this ore under a NML-DRDO collaborative Project (Chakravorty, Personal Communication). While the IBM flow-sheet involves pre-concentration by gravity methods-spiralling followed by tabling, the BARC flow-sheet resorts to WHIMS followed by reverse flotation of mica for the pre-concentration. At first sight the IBM flow-sheet appears more attractive, but the techno-economic feasibility of either of the flow-sheets will depend on the particle size of liberation, and the grind needed for optimum liberation of wolframite. With relatively coarser grind of liberation $(+100$ to +150 mesh), the IBM flow-sheet will be more advantageous; but with any finer grind necessary for liberation $(-150 \mathrm{mesh})$, this process is unlikely to yield high 


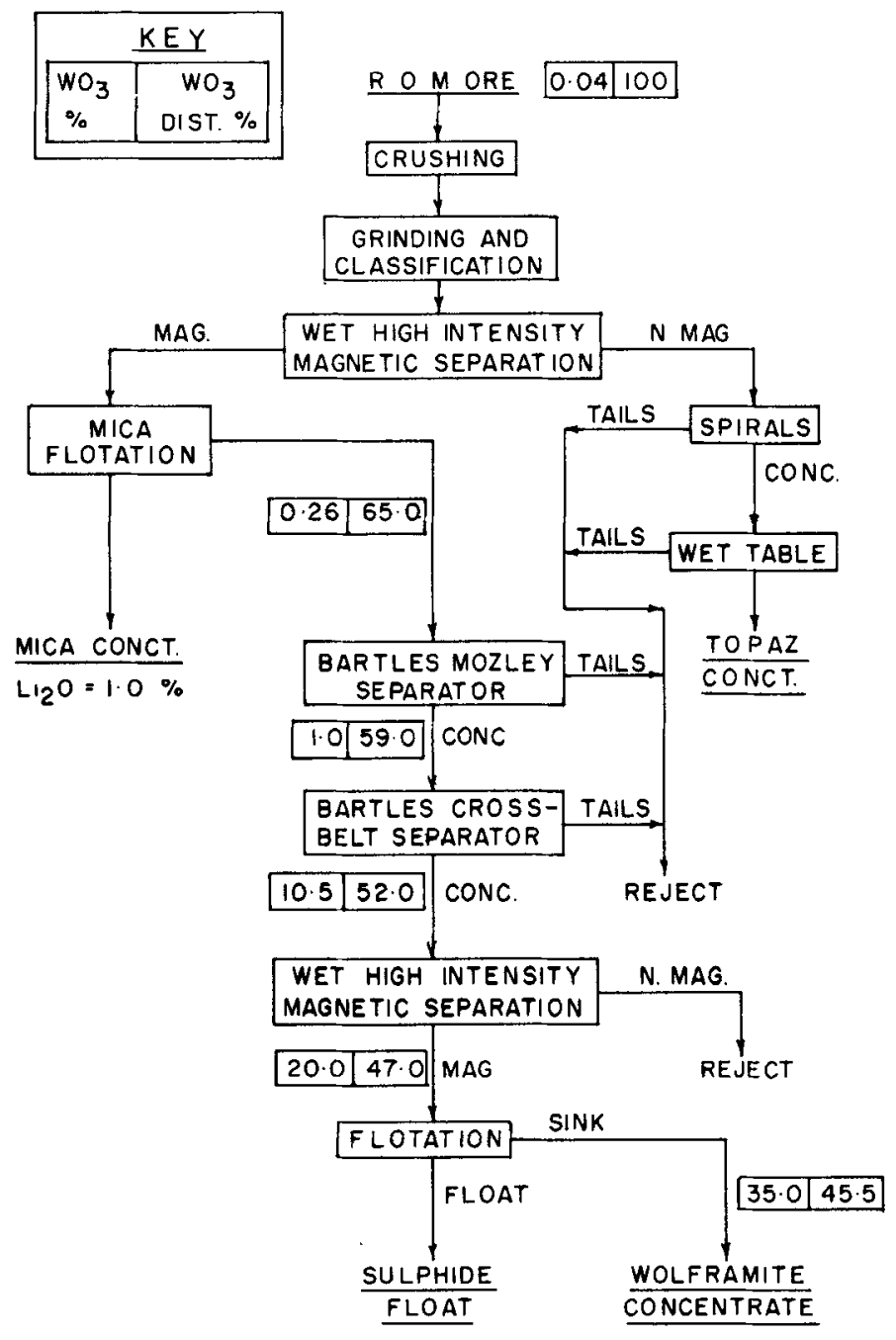

Figure 9. Flow-sheet (schematic) suggested by BARC for the benefieiation of granite-type tungsten ore from Degana, with anticipated tungsten material balance.

recoveries owing to the use of spirals, which are not effective in fine sizes. In such cases the BARC flow-sheet will be more effective, as WHIMS is an efficient process even upto about $10 \mu \mathrm{m}$ particle size.

\section{Balda tungsten deposit}

The tungsten mineralization in the Balda area of Sirohi District of Rajasthan is associated with a leucogranite locally known as Balda Granite, which belongs to the Erinpura Granite Suite. The tungsten mineralization in the form of wolframite occurs in shear zones and greisenised pegmatites localized at the contact of metasediments and the intrusive granite. The quartz veins and greisenised pegmatites characteristically contain, besides quartz, alkali-felspar and sodic plagioclase, tourmaline, zinnwaldite, 
Table 8. Summary of IBM test results on Balda tungsten ore (Greisen Type, Feed Grade $0.2 \% \mathrm{WO}_{3}$ ).

\begin{tabular}{|c|c|c|c|c|}
\hline & Feed grade & $\begin{array}{l}\text { Concentrate } \\
\text { grade } \mathrm{WO}_{3} \%\end{array}$ & $\begin{array}{c}\mathrm{WO}_{3} \\
\text { Recovery \% }\end{array}$ & Major process steps \\
\hline 1. & $0 \cdot 197$ & $16 \cdot 0$ & $40 \cdot 12$ & Tabling, Mag. Sepn. \\
\hline 2. & 0.21 & $23 \cdot 56$ & $51 \cdot 54$ & Jigging, Tabling, HTS \\
\hline 3. & $0 \cdot 21$ & $15 \cdot 77$ & 68.09 & Jigging, Tabling $(-35 \#)$ \\
\hline 4. & $0 \cdot 21$ & $15 \cdot 28$ & $69 \cdot 36$ & Jigging, Tabling \\
\hline 5. & $0 \cdot 21$ & 26.08 & $57 \cdot 92$ & Jigging, Tabling \\
\hline 6. & $0 \cdot 21$ & $14 \cdot 82$ & $60 \cdot 18$ & Jigging, Tabling \\
\hline 7. & 0.44 & $45 \cdot 3$ & $70 \cdot 7$ & Tabling \\
\hline 8. & $0 \cdot 17$ & $37 \cdot 58$ & $39 \cdot 60$ & Tabling $(-100 \#)$ \\
\hline 9. & $0 \cdot 20$ & $18 \cdot 47$ & $51 \cdot 32$ & Tabling $(-35 \#)$ \\
\hline 10. & $0 \cdot 20$ & $10 \cdot 78$ & $49 \cdot 23$ & Tabling $(-65 \#)$ \\
\hline 11. & $0 \cdot 16$ & 23.45 & $66 \cdot 11$ & Tabling \\
\hline 12. & $0 \cdot 17$ & $10 \cdot 0$ & $30 \cdot 00$ & Tabling, Mozley LMS \\
\hline 13. & $0 \cdot 16$ & $40 \cdot 20$ & $74 \cdot 45$ & \\
\hline 14. & $0 \cdot 23$ & $57 \cdot 33$ & $50 \cdot 00$ & Tabling, HTS \\
\hline 15. & $0 \cdot 19$ & $5 \cdot 01$ & 13.65 & Tabling, Mozley LMS \\
\hline
\end{tabular}

Table 9. Summary of IBM test results on Balda tungsten ore (Granite Type, Feed Grade $<0 \cdot 1 \% \mathrm{WO}_{3}$ ).

\begin{tabular}{|c|c|c|c|c|}
\hline & Feed grade & $\begin{array}{l}\text { Concentrate } \\
\text { grade } \mathrm{WO}_{3} \%\end{array}$ & $\begin{array}{c}\mathrm{WO}_{3} \\
\text { Recovery \% }\end{array}$ & Major process steps \\
\hline 1. & 0.081 & $19 \cdot 00$ & $50 \cdot 00$ & Tabling, Mag. Sepn. (-65\#) \\
\hline 2. & $0 \cdot 10$ & $4 \cdot 12$ & $49 \cdot 75$ & Gravity methods \\
\hline 3. & $0 \cdot 045$ & 0.87 & $32 \cdot 51$ & Tabling ( $-100 \#)$ \\
\hline 4. & 0.035 & $0 \cdot 84$ & $30 \cdot 2$ & Tabling \\
\hline 5. & 0.08 & 0.79 & $42 \cdot 38$ & Tabling $(-65 \#)$ \\
\hline 6. & 0.045 & $0-08$ & $24 \cdot 68$ & Tabling $(-100 \#)$ \\
\hline 7. & 0.08 & $6 \cdot 24$ & $34 \cdot 0$ & Tabling, Mozley LMS \\
\hline 8. & $0 \cdot 045$ & $0 \cdot 16$ & $53 \cdot 43$ & Flotation \\
\hline 9. & 0.007 & $2 \cdot 13$ & $36 \cdot 78$ & Tabling, Mozley LMS \\
\hline 10. & $0 \cdot 015$ & $4 \cdot 0$ & $39 \cdot 26$ & Tabling, Mozley LMS \\
\hline 11. & $0 \cdot 013$ & $0-59$ & $27 \cdot 5$ & Tabling $(-35 \#)$ \\
\hline 12. & $0 \cdot 04$ & 9.98 & $64 \cdot 4$ & Tabling, Mozley LMS \\
\hline 13. & 0.08 & $6 \cdot 24$ & $34 \cdot 00$ & Flotation \\
\hline 14. & 0.0086 & $2 \cdot 17$ & $20 \cdot 95$ & Tabling, Mozley LMS \\
\hline 15. & 0.03 & $2 \cdot 17$ & $6 \cdot 5$ & Tabling, Mozley LMS \\
\hline
\end{tabular}

fluorite, topaz, apatite, rutile, arsenopyrite, pyrite, chalcopyrite and wolframite (Bhattacharjee et al 1987).

During mid- and late eighties, Indian Bureau of Mines had carried out indicative batch beneficiation tests on a number of samples from Balda (Rao and Subrahmanyam 1988). The process followed in most of the tests is the same, concentration by gravity beneficiation methods (jigging and/or tabling) after size reduction, followed by upgradation by magnetic separation or electrostatic separation, and in some tests by separation in Mozley mineral separator. A few samples have also been processed by flotation, but the collector reagent used are not indicated. However none of the 


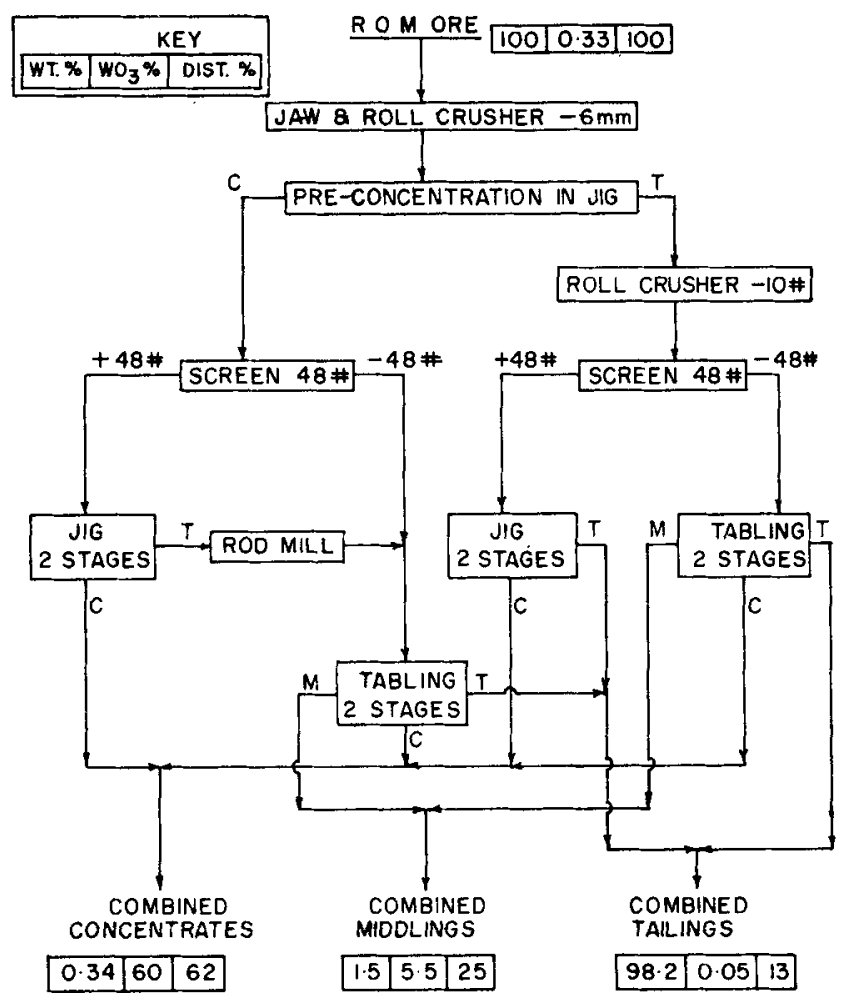

Figure 10. Schematic flow-sheet for the beneficiation of Balda tungsten ore, followed in BARC test, with metallurgical material balance.

flotation tests have yielded any worthwhile concentration. Two types of samples have been tested, a lean grade granitic ore ( $\mathrm{WO}_{3} \%<0 \cdot 01$ to $\left.0 \cdot 10\right)$, and a medium grade vein sample $\left(\mathrm{WO}_{3} \% 0.16\right.$ to 0.23 , and in one case $0.44 \%$ ). The results obtained are summarized in tables 8 and 9 . The medium grade samples have yielded very encouraging results, indicating their amenability for beneficiation.

The bulk sample of the Balda ore studied by BARC (Shukla and Rao-under publication) essentially consisted of quartz veins and greisenised pegmatite veins and had the following mineralogical composition: Quartz and felspar 70\%, Mica and Tourmaline $28 \%$, Fluorite $1.5 \%$, Wolframite and other opaque minerals $0.5 \%$. The sample analyzed 0.30 to $0.35 \% \mathrm{WO}_{3}$. The flow-sheet followed for the beneficiation of the ore is schematically illustrated in figure 10 . The sample is crushed in a roll crusher to all passing through $6 \mathrm{~mm}$ screen. The crushed product is pre-concentrated in a laboratory jig. The pre-concentrate is screened at $48 \#$ and the screen coarse is further concentrated in a cleaner jig, and the screen fines in a shaking table. The tailings of the rougher jig was crushed to all passing through $10 \#$, classified at $48 \#$, and the coarse and fine fractions are processed on jigs and shaking tables respectively, in two stages, rougher and cleaner. During tabling a middling fraction was also collected. The final result obtained are also given in figure 10 . The combined concentrate analyzed $60.5 \%$ $\mathrm{WO}_{3}$ at $61.8 \%$ recovery, the combined middlings assayed $5.5 \% \mathrm{WO}_{3}$ at $24.6 \%$ distribution. It should be possible to improve the final concentrate recovery by recirculation of middling streams at appropriate points. 


\section{Khobna-Kuhi-Agargaon tungsten ore}

Occurrence of a small tungsten deposit at Agargaon, falling in the Proterozoic Sakoli basin, was established during $1966-69$ by Geological Survey of India, and later during 1978-79 tungsten occurrence in a number of localities in the basin was observed. This belt of tungsten occurrence is called the Kuhi-Khobna-Saongi belt (Bhoskar et al 1987). Geologically, tungsten mineralization is located in the north-western margin of the Sakoli synclinorium. The mineralization, predominantly scheelite with minor wolframite, is confined to greisen zones with swarms of tourmaline veins in a host of quartz-chlorite-mica schist.

In the Khobna area, the tungsten mineralization occurs in a zone called 'Main Greisen Zone', containing two types of greisen veins, viz. tourmaline-rich and quartzrich greisens. Besides major amounts of quartz, mica and tourmaline, the greisen contains varying quantities of potash felspar, chlorite, apatite, fluorite, calcite, sphene, topaz and opaque minerals. While scheelite is the predominant tungsten mineral in the oxidized zone of the greisens, in the primary zone wolframite is also frequently observed, though still scheelite is dominant. The opaque minerals identified include ilmenite, rutile, magnetite, hematite, pyrite, pyrrhotite, chalcopyrite, molybdenite,

Table 10. Mineralogical and chemical composition of Khobna tungsten ore (Ore samples investigated by BARC).

\begin{tabular}{|c|c|c|c|c|}
\hline \multirow[b]{2}{*}{ Mineral } & \multicolumn{2}{|c|}{ Primary ore } & \multicolumn{2}{|c|}{ Oxidized ore } \\
\hline & 1 & II & I & II \\
\hline Quartz and felspars & $59 \cdot 9$ & $64 \cdot 5$ & $64 \cdot 5$ & \\
\hline Micaceous minerals & 27.7 & $29 \cdot 1$ & $27 \cdot 3$ & \\
\hline Tourmaline & $9 \cdot 0$ & 2.9 & $3 \cdot 2$ & \\
\hline Garnet & 0.7 & & $0 \cdot 2$ & \\
\hline Apatite & $0 \cdot 1$ & $1 \cdot 1$ & $0 \cdot 2$ & \\
\hline Calcite & 0.1 & & & \\
\hline Fluorite & & & $1 \cdot 7$ & \\
\hline Scheelite & 0.4 & $0 \cdot 3$ & $0 \cdot 25$ & 0.25 \\
\hline Wolframite & $0 \cdot 2$ & $0 \cdot 01$ & 0.05 & 0.01 \\
\hline Magnetite & $0 \cdot 35$ & 0.17 & $2 \cdot 10$ & \\
\hline $\begin{array}{l}\text { Other oxide minerals } \\
\text { (Ilmenite, Rutile, } \\
\text { Hematite, Goethite etc.) }\end{array}$ & $0 \cdot 37$ & 0.85 & & \\
\hline Other opaques (Sulphides) & $1 \cdot 13$ & 1.07 & $0 \cdot 40$ & \\
\hline Pyrite & $0 \cdot 40$ & $0 \cdot 44$ & & \\
\hline Pyrrhotite & $0 \cdot 20$ & $0 \cdot 15$ & & \\
\hline Chalcopyrite, etc & $0 \cdot 40$ & $0 \cdot 4$ & & \\
\hline Molybdenite & 0.03 & 0.09 & & \\
\hline Others & $0 \cdot 10$ & $\mathrm{Tr}$ & & \\
\hline \multicolumn{5}{|l|}{ Chemical Analysis: } \\
\hline $\mathrm{WO}_{3}$ & $0 \cdot 36$ & $0 \cdot 274$ & $0 \cdot 26$ & 0.216 \\
\hline $\mathrm{Cu}$ & $0 \cdot 16$ & & 0.078 & \\
\hline $\mathrm{Ni}$ & 0.005 & & 0.005 & \\
\hline Co & $0 \cdot 004$ & & 0.003 & \\
\hline Mo & 0.01 & & $<0.01$ & \\
\hline $\mathrm{Sn}$ & $<0 \cdot 1$ & & & \\
\hline
\end{tabular}




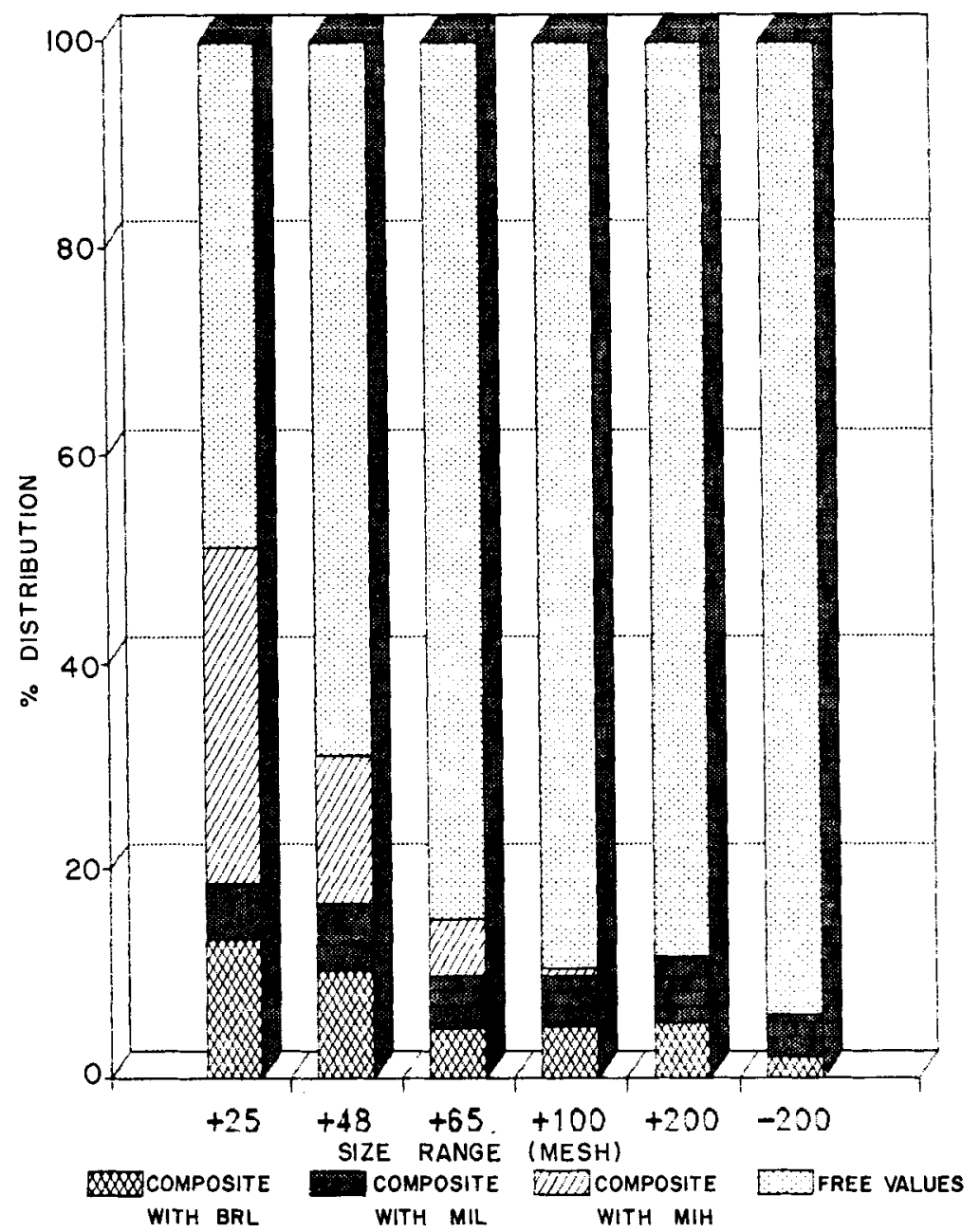

Figure 11. Liberation of tungsten values in different size fractions of Khobna tungsten ore (primary type).

bismuth, bismuthinite, sphalerite, galena etc. in minor to trace amounts. Magnetite has given place to hematite and goethite in the oxidized zone. Also the sulphide mineral content in the oxidized zone is very minor.

Batch as well as semi pilot plant scale studies have been carried out on samples of ore collected from both oxidized and primary zones, by BRGM (France), IBM and BARC (ODS), at the request of MECL under BRGM-MECL Tin Tungsten Collaborative Programme. While the test results of BARC are described in detail in the following pages, the results obtained by BRGM and IBM are briefly discussed.

\subsection{BARC test results}

8.1a Ore characteristics: The mineralogical and chemical characteristics of two samples each from the oxidized and primary zone supplied by MECL are given in 


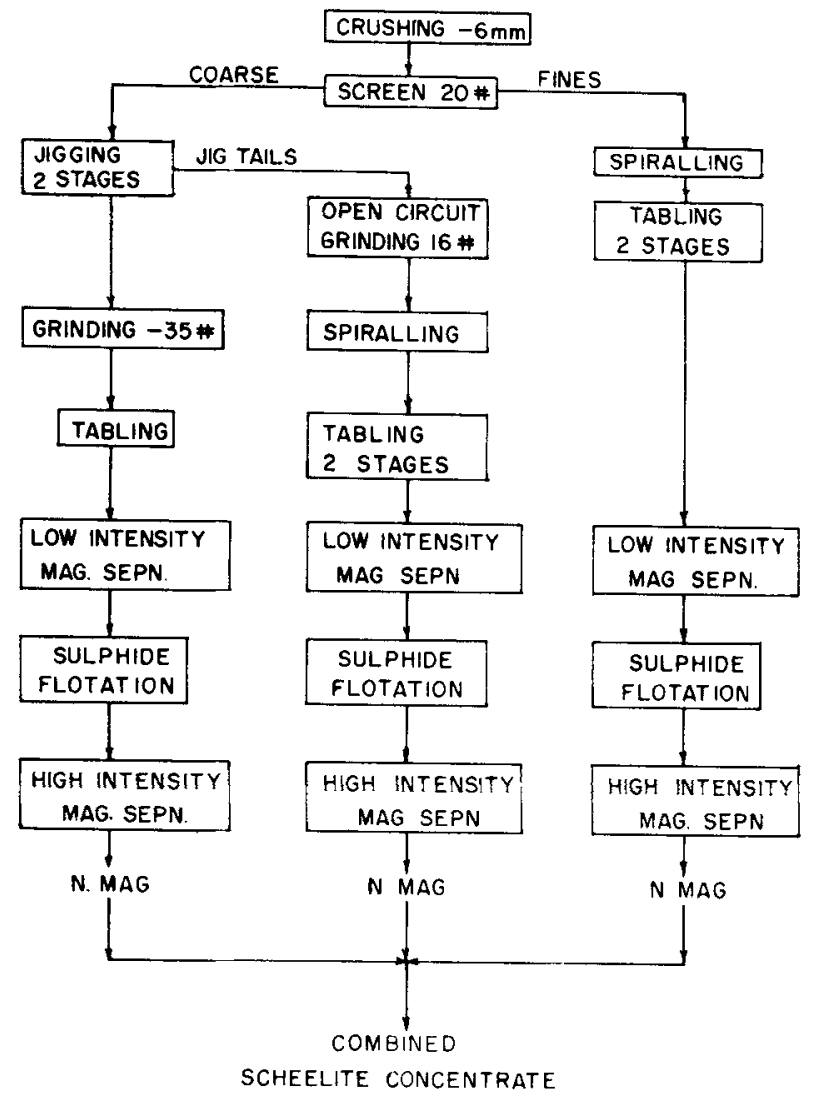

Figure 12. Flow-sheet-I followed in BARC tests for beneficiation of Khobna tungsten ore.

table 10 (Narasimhan 1989; Shukla et al 1991). In both the samples at about $-65 \#$ nearly $90 \%$ of the scheelite values are liberated, which can be taken as optimum liberation size. Liberation characteristic of the primary ore is illustrated in figure 11. Chemically the oxidized samples analyzed 0.26 and $0.22 \% \mathrm{WO}_{3}$, while the primary zone samples analyzed 0.36 and $0 \cdot 27 \% \mathrm{WO}_{3}$.

8.1b Batch beneficiation tests: During the initial stages of testing (Shukla et al 1989), it was found that the high mica content of the samples was presenting problems in comminution. Grinding the sample to liberation size was resulting in undue over grinding of highly brittle sheelite, affecting its recovery in the subsequent gravity operations. Reduction in size to all passing through $16 \#(1 \mathrm{~mm})$ by open circuit grinding in a peripheral discharge rod mill was found adequate to liberate most of the scheelite, at the same time avoiding over grinding of scheelite. Based on detailed batch tests, two flow-sheets were developed for large scale tests. These are schematically illustrated in figures 12 and 13 (Shukla et al 1991).

Flow-sheet I: Involves (i) size reduction in stages to all passing through $6 \mathrm{~mm}$ screen, (ii) screening at 20 mesh, (iii) pre-concentration of the coarse fraction by jigging followed by tabling of the jig concentrate after regrinding, (iv) pre-concentration of the 


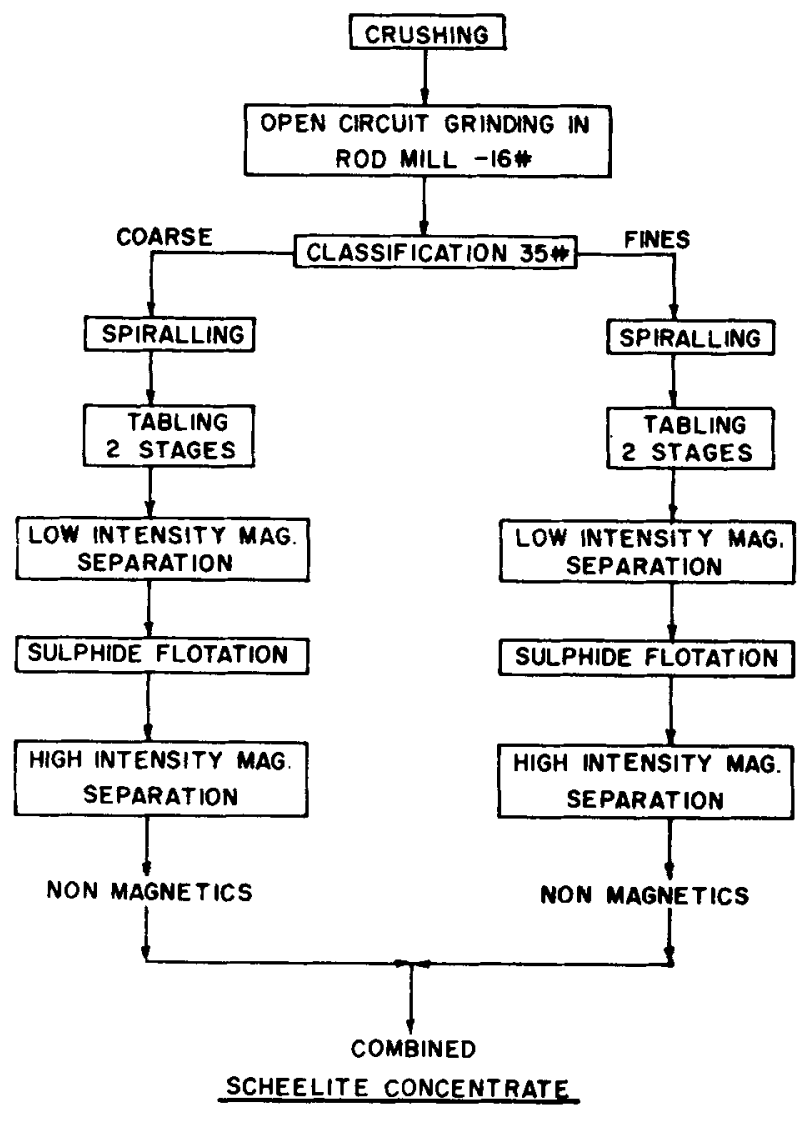

Figure 13. Flow-sheet-Il followed in BARC tests for beneficiation of Khobna tungsten ore.

fines stream ( $-20 \#)$ by spirals followed by tabling, and (v) open circuit grinding of the jig tails to all passing through $16 \#$, followed by processing as in (iv) above.

Flow-sheet II: Involves (i) size reduction to all passing through 16 \#creen, (ii) classification at a cut size of about $35 \#$ and (iii) pre-concentration of both the coarse and fine streams by spiralling followed by tabling.

Upgradation: The pre-concentrates are upgraded by low intensity magnetic separation to remove magnetite and other iron oxide minerals, followed by xanthate flotation to remove sulphides, and finally by high intensity magnetic separation to concentrate scheelite in the nonmagnetic fraction. Any wolframite values present will be concentrated in the magnetic fraction of the last stage, along with tourmaline, garnet and some iron oxide minerals. This fraction can be further upgraded by high tension separation.

\subsection{Large scale beneficiation tests}

8.2a Tests with primary ore sample (sample I) (Test no. 1): This test was carried out following the flow-sheet I given above. At the end of the pre-concentration stages, the recoveries and assays of the pre-concentrates and the final concentrates obtained after upgradation by magnetic separation and flotation are given in table 11. 
Table 11. Results of semi pilot plant scale tests on primary and oxidized ore samples from Khobna following flow-sbeet I (figure 12).

\begin{tabular}{|c|c|c|c|c|c|c|}
\hline \multirow[b]{2}{*}{ Stream } & \multicolumn{3}{|c|}{$\begin{array}{c}\text { Primary ore sample } \\
\text { (Feed assay } 0.27 \% \mathrm{WO}_{3} \text { ) }\end{array}$} & \multicolumn{3}{|c|}{$\begin{array}{c}\text { Oxidized ore sample } \\
\left(\text { Feed assay } 0.22 \% \mathrm{WO}_{3}\right)\end{array}$} \\
\hline & Wt. $\%$ & $\begin{array}{c}\mathrm{WO}_{3} \\
\text { assay \% }\end{array}$ & $\begin{array}{c}\mathbf{W O}_{3} \\
\text { dist. } \%\end{array}$ & Wt. $\%$ & $\begin{array}{c}\mathrm{WO}_{3} \\
\text { assay } \%\end{array}$ & $\begin{array}{l}\mathrm{WO}_{3} \\
\text { dist. } \%\end{array}$ \\
\hline \multicolumn{7}{|l|}{ Pre-concentration stage } \\
\hline $\begin{array}{l}-8+20 \# \text {, Jigging } \\
\text { followed by tabling }\end{array}$ & 0.28 & $22 \cdot 5$ & $21 \cdot 4$ & 0.09 & $36 \cdot 0$ & $16 \cdot 8$ \\
\hline $\begin{array}{l}-8+20 \#, \text { Spiralling } \\
\text { followed by tabling of } \\
\text { reground jig tails }\end{array}$ & $0 \cdot 10$ & $30 \cdot 1$ & $9 \cdot 6$ & 0.09 & $29 \cdot 0$ & $12 \cdot 8$ \\
\hline $\begin{array}{l}-20 \#, \text { Spiralling } \\
\text { followed by tabling }\end{array}$ & $1 \cdot 10$ & $10 \cdot 6$ & $43 \cdot 3$ & 0.28 & 31.5 & $39 \cdot 6$ \\
\hline Total & $1 \cdot 48$ & $14 \cdot 2$ & $74 \cdot 3$ & 0.46 & 31.9 & $68 \cdot 2$ \\
\hline \multicolumn{7}{|l|}{ After upgradation } \\
\hline $\begin{array}{l}-8+20 \#, \text { Jigging } \\
\text { followed by tabling }\end{array}$ & 0.09 & $60 \cdot 3$ & $19 \cdot 0$ & 0.05 & 65.0 & $15 \cdot 2$ \\
\hline $\begin{array}{l}-8+20 \# \text {, Spiralling } \\
\text { and tabling of reground } \\
\text { jig tails, }\end{array}$ & 0.04 & $70 \cdot 0$ & $9 \cdot 1$ & 0.04 & $54 \cdot 0$ & $11 \cdot 5$ \\
\hline $\begin{array}{l}-20 \#, \text { Spiralling } \\
\text { followed by tabling }\end{array}$ & 0.16 & $64 \cdot 3$ & $39 \cdot 4$ & 0.13 & $62 \cdot 2$ & $38 \cdot 2$ \\
\hline Total & 0.29 & 63.8 & $67 \cdot 5$ & 0.22 & $61 \cdot 2$ & $64 \cdot 9$ \\
\hline
\end{tabular}

Another $8 \cdot 6 \%$ of $\mathrm{WO}_{3}$ values were recovered by scavenging the spiral middlings, though at a lower grade of about $2 \cdot 1 \% \mathrm{WO}_{3}$. The results show that the primary jig tails carry appreciable $\mathrm{WO}_{3}$ values in unliberated state, and that it is necessary to process the same after regrinding. Thus the flow-sheet does not in any way reduce the overall grinding requirements.

Test no. 2: In this test the flow-sheet II is followed. After size reduction in a roll crusher to all passing through $5 \mathrm{~mm}$ screen, the ore was ground in an open circuit rod mill to all passing through $1 \mathrm{~mm}$. The rod mill discharge was classified in a stationary CTS screen with a separation size of $460 \mu \mathrm{m}$, and both the coarse and fines streams were separately processed in spirals followed by tables. The grades and recoveries obtained at the end of the pre-concentrate stage and at the final stage are given in table 12 .

It is clear that in order to obtain a better grade final scheelite concentrate, it is necessary to have higher grade pre-concentrates than what was obtained in this experiment, which means that during tabling stage weight collection should be optimized.

Test no. 3: During the test no. 2 it was observed that the feed to the rod mill (i.e. the roll crushed product) contained as much as $30 \%$ finer than $1 \mathrm{~mm}$ size, which resulted in over grinding of the already liberated scheelite in the rod mill. In this experiment this was avoided by pre-screening the roll crushed product through $1 \mathrm{~mm}$ screen, and subjecting only the screen oversize to grinding in the open circuit rod mill. Further processing was the same as in flow-sheet II. The results obtained at the pre-concentrate and the final stage after upgradation are also included in table 12 . It was seen that even 
Table 12. Results of semi pilot plant scale tests on primary ore samples from Khobna following flow-sheet II (figure 13).

\begin{tabular}{|c|c|c|c|c|c|c|}
\hline \multirow[b]{2}{*}{ Stream } & \multicolumn{3}{|c|}{ At pre-concentration stage } & \multicolumn{3}{|c|}{ After final upgradation } \\
\hline & Wt. \% & $\begin{array}{c}\mathrm{WO}_{3} \\
\text { Assay \% }\end{array}$ & $\begin{array}{c}\mathrm{WO}_{3} \\
\text { Dist. \% }\end{array}$ & Wt. $\%$ & $\begin{array}{c}\mathrm{WO}_{3} \\
\text { Assay \% }\end{array}$ & $\begin{array}{c}\mathrm{WO}_{3} \\
\text { Dist. \% }\end{array}$ \\
\hline \multicolumn{7}{|l|}{ Flow-sheet II: } \\
\hline $\begin{array}{l}+460 \mu \mathrm{m}, \text { Spiralling } \\
\text { followed by tabling }\end{array}$ & 0.35 & $8 \cdot 32$ & $12 \cdot 9$ & $0 \cdot 10$ & $26 \cdot 3$ & $11 \cdot 3$ \\
\hline$-460 \mu \mathrm{m}$, Spiralling & 0.88 & $15 \cdot 00$ & $59 \cdot 5$ & 0.23 & $53 \cdot 3$ & $55 \cdot 9$ \\
\hline Total & $1 \cdot 23$ & $13 \cdot 10$ & $72 \cdot 4$ & $0 \cdot 33$ & $45 \cdot 1$ & $67 \cdot 2$ \\
\hline \multicolumn{7}{|l|}{ Modified flow-sheet 11 : } \\
\hline $\begin{array}{l}+460 \mu \mathrm{m} \text {, Spiralling } \\
\text { followed by tabling }\end{array}$ & $0 \cdot 10$ & $26 \cdot 3$ & $11 \cdot 3$ & $0 \cdot 18$ & $24 \cdot 3$ & $17 \cdot 8$ \\
\hline $\begin{array}{l}-460 \mu \mathrm{m}, \text { Spiralling } \\
\text { followed by tabling }\end{array}$ & $0: 23$ & $53 \cdot 3$ & $55 \cdot 9$ & 0.09 & $48 \cdot 0$ & $16 \cdot 8$ \\
\hline Total & 0.33 & $45 \cdot 1$ & 67.2 & $0 \cdot 31$ & $58 \cdot 9$ & $72 \cdot 8$ \\
\hline
\end{tabular}

Table 13. Results of semi pilot plant scale tests on oxidized ore sample from Khobna following flow-sheet II (figure 13).

\begin{tabular}{|c|c|c|c|c|c|c|}
\hline \multirow[b]{2}{*}{ Stream } & \multicolumn{3}{|c|}{ At pre-concentration stage } & \multicolumn{3}{|c|}{ After final upgradation } \\
\hline & Wt. \% & $\begin{array}{c}\mathrm{WO}_{3} \\
\text { Assay \% }\end{array}$ & $\begin{array}{c}\mathrm{WO}_{3} \\
\text { Dist. \% }\end{array}$ & Wt. \% & $\begin{array}{c}\mathrm{WO}_{3} \\
\text { Assay \% }\end{array}$ & $\begin{array}{c}\mathrm{WO}_{3} \\
\text { Dist. \% }\end{array}$ \\
\hline \multicolumn{7}{|l|}{ Flow-sheet II: } \\
\hline $\begin{array}{l}+460 \mu \mathrm{m}, \text { Spiralling } \\
\text { followed by tabling }\end{array}$ & $0 \cdot 13$ & 16.9 & 10.8 & 0.06 & $36 \cdot 8$ & $10 \cdot 6$ \\
\hline$-460 \mu \mathrm{m}$, Spiralling & 0.40 & $32 \cdot 1$ & $60 \cdot 7$ & $0 \cdot 20$ & $60 \cdot 5$ & $58 \cdot 5$ \\
\hline Total & 0.53 & $28 \cdot 3$ & $71 \cdot 5$ & 0.26 & $55 \cdot 0$ & $69 \cdot 1$ \\
\hline \multicolumn{7}{|l|}{ Modified flow-sheet II: } \\
\hline $\begin{array}{l}+460 \mu \mathrm{m}, \text { Spiralling } \\
\text { followed by tabling }\end{array}$ & 0.15 & $34 \cdot 2$ & $19 \cdot 0$ & 0.08 & $60-0$ & $17 \cdot 8$ \\
\hline $\begin{array}{l}-460 \mu \mathrm{m}, \text { Spiralling } \\
\text { followed by tabling }\end{array}$ & $0-42$ & $34 \cdot 2$ & $54 \cdot 9$ & 0.20 & $68 \cdot 8$ & $51 \cdot 2$ \\
\hline Total & 0.57 & $34 \cdot 2$ & $73 \cdot 9$ & 0.28 & $66-2$ & $69 \cdot 0$ \\
\hline
\end{tabular}

though higher $\mathrm{WO}_{3}$ distribution reported in the rougher spiral tails, better stage recoveries and grades of concentrates were realized.

Flow-sheet no. II as followed in test no. 3 has given the best result in terms of recovery. It should be possible to improve the grade by optimizing the weight per cent collection in the pre-concentration stage, or alternatively by subjecting the final concentrate to a further stage of cleaning on tables.

8.2b Tests with oxidized ore sample (sample 2) (Test no. 1): This test was carried out following Flow-sheet I. Because of the near total absence of sulphides and magnetite in 
Table 14. Results of tests on upgradation of the concentrates.

\begin{tabular}{lcccc}
\hline & \multicolumn{2}{c}{$\begin{array}{c}\text { Sample 1 } \\
\text { (primary ores) }\end{array}$} & \multicolumn{2}{c}{$\begin{array}{c}\text { Sample 2 } \\
\text { (oxidized ore) }\end{array}$} \\
Product & WO $_{3}$ assay $\%$ & WO $_{3}$ dist. $\%$ & WO $_{3}$ assay $\%$ & WO $_{3}$ dist. $\%$ \\
\hline Table conct. & 73.6 & 86.3 & 75.0 & 80.0 \\
Table tails & 13.6 & 13.7 & 29.4 & 20.0 \\
Feed & 45.8 & 100.0 & 57.2 & 100.0 \\
\hline
\end{tabular}

Table 15. Mineralogical composition and partial chemical analyses of upgraded scheelite concentrates from Khobna (BARC Tests)

\begin{tabular}{lcc}
\hline & Primary ore sample & Oxidized ore sample \\
\hline Mineralogical composition & & \\
Scheelite & $92 \cdot 0$ & $95 \cdot 0$ \\
Quartz & 1.0 & 0.2 \\
Mica & 0.5 & 0.1 \\
Tourmaline & 0.2 & 0.2 \\
Fluorite, Apatite and & 3.3 & 3.0 \\
$\quad$ Topaz & & \\
Pyrite & 2.0 & 1.0 \\
Chalcopyrite etc. & 1.0 & 0.1 \\
Iron oxides & - & 0.5 \\
Total & 100.0 & 100.0 \\
Chemical Analysis: $_{W_{3}}$ & & \\
$\mathrm{SiO}_{2}$ & 73.6 & 75.0 \\
$\mathrm{~S}_{\text {Fe }} \mathrm{O}_{3}$ & 1.73 & 0.59 \\
\hline
\end{tabular}

this sample from the oxidized zone of mineralization, the stages of flotation of sulphides and low intensity magnetic separation were skipped. Grades and recoveries of the pre-concentrates and the final concentrates are given in table 11.

It may be noted that because of the near absence of wolframite in this sample, high stage recoveries were obtained in the final scheelite concentrates during magnetic separation.

Test no. 2: In this test the flow-sheet II was followed. Here too low intensity magnetic separation and flotation stages were omitted. The results obtained are given in table 13.

Test no. 3: This test followed the flow-sheet of test 3 with sample I, except for the sulphide flotation stage. The results after pre-concentration and final stages are given in table 13.

8.2c Final upgradation: The final scheelite concentrates obtained in the different experiments both with primary and oxidized samples, assay 45 to $66 \% \mathrm{WO}_{3}$ at recoveries between 65 to $73 \%$. Microscopic examination of these concentrates revealed 
Table 16. $\mathrm{Cu}, \mathrm{Mo}$ and $\mathrm{Ag}$ contents of sulphide floats obtained from primary ore sample from Khobna (BARC Tests).

\begin{tabular}{|c|c|c|c|c|c|}
\hline Test & Stream & $W t \%$ & $\mathrm{Cu} \%$ & Mo \% & $\mathrm{Ag} \mathrm{ppm}$ \\
\hline \multirow[t]{2}{*}{ No. 1} & $\begin{array}{c}+20 \text { \# Float from } \\
\text { jig concentrate }\end{array}$ & 0.02 & 4.93 & $5 \cdot 29$ & 200 \\
\hline & $\begin{array}{l}-20 \text { \# Float from } \\
\text { cleaner table conc. }\end{array}$ & 0.20 & 4.91 & 1.06 & 150 \\
\hline \multirow[t]{3}{*}{ No. 2} & $\begin{array}{l}+460 \mu \mathrm{m}, \text { Float from } \\
\text { cleaner table conc. }\end{array}$ & 0.04 & 4.85 & nd & \\
\hline & $\begin{array}{l}-460 \mu \mathrm{m} \text {, Float from } \\
\text { cleaner table conc. }\end{array}$ & $0 \cdot 11$ & $4 \cdot 66$ & $1 \cdot 10$ & 120 \\
\hline & $\begin{array}{l}-460 \mu \mathrm{m}, \text { Float from } \\
\text { cleaner table tails }\end{array}$ & 0.08 & 4.63 & $1 \cdot 11$ & 120 \\
\hline \multirow[t]{2}{*}{ No. 3} & $\begin{array}{c}+460 \mu \mathrm{m}, \text { Float from } \\
\text { cleaner table conc. }\end{array}$ & 0.02 & $4 \cdot 61$ & 485 & 140 \\
\hline & $\begin{array}{l}-460 \mu \mathrm{m} \text {, Float from } \\
\text { cleaner table conc. }\end{array}$ & 0.11 & 4.75 & 0.85 & 120 \\
\hline
\end{tabular}

that the main contaminants are quartz, fluorite, topaz and minor sulphides, mainly pyrite. The marketable grade of scheelite concentrate is $+70 \% \mathrm{WO}_{3}$ and in order to achieve the same it is necesary to upgrade the concentrates. An attempt was made to do so by gravity methods, by subjecting the final concentrates to a stage of tabling (recleaner stage). This test was carried out by mixing the concentrates obtained in the different experiments. Table 14 gives the results.

Mineralogical and partial chemical analyses of the above table concentrates are given in table 15 .

8.2d Improvements in recovery: There is scope to improve the recovery further by scavenging the spiral middlings, and by recirculating it along with table cleaner tails at appropriate stages. By this 4-5\% increase in the recovery can be anticipated. Similarly the magnetic fraction of the high intensity magnetic separation stage constitutes an important low grade concentrate, which can be upgraded by gravity separation. Most of the tungsten values contained in them is due to wolframite. It may be noted here that in the primary sample, wolframite is often an important constituent. In one of the bore hole composite sample made available by MECL earlier, wolframite contributed nearly one third of the tungsten distribution in the sample.

8.2e By-products: The primary ore sample contains minor values of copper, molybdenum and silver, which have the potential to be recovered as valuable byproducts. These values are concentrated in the float fraction of the sulphide flotation stage. The $\mathrm{Cu}, \mathrm{Mo}$ and $\mathrm{Ag}$ contents of important sulphide floats obtained in the three tests with the primary sample are given in table 16. Under optimum conditions the total weight percent collection in all the flotation concentrate streams will be 0.25 to $0.3 \%$. The average grade of these combined concentrates will be $\mathrm{Cu} 4$ to $5 \%$, Mo 1.4 to $1.6 \%$ and $\mathrm{Ag} 120$ to $150 \mathrm{ppm}$. It should be possible to obtain a high grade molybdenite concentrate by differential flotation of the combined flotation concentrate. 


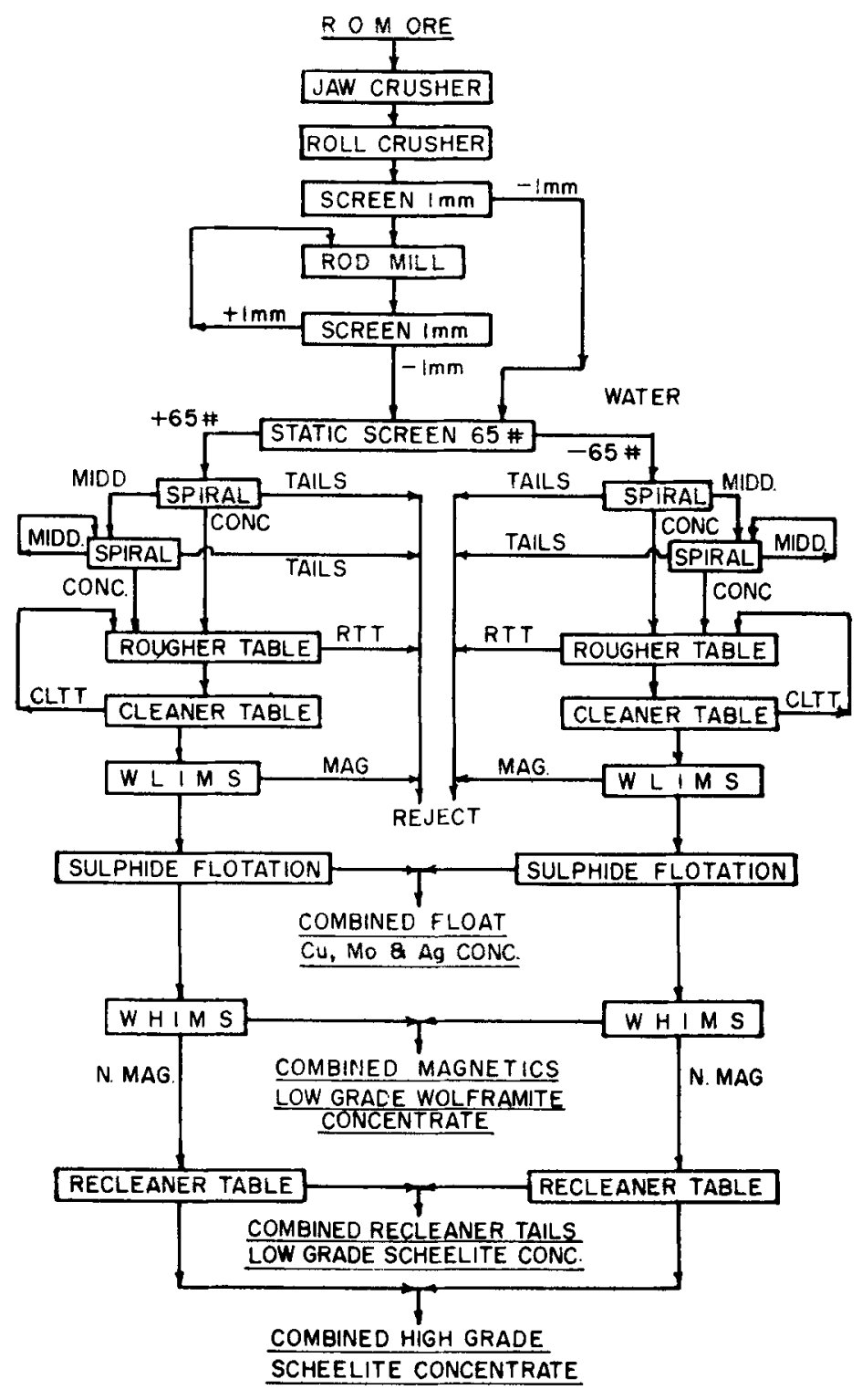

Figure 14. Industrial flow-sheet (schematic) suggested by BARC for the beneficiation of Khobna tungsten ore.

8.2f Industrial flow-sheet: On the basis of an in depth analysis of the results obtained during batch and semi pilot plant scale beneficiation tests, an industrial flow-sheet has been evolved (Shukla et al 1991). There is no basic difference between the primary and the oxidized ore in their beneficiation characteristics, except the necessity to have one or two more steps in the case of primary ore containing appreciable magnetite and sulphides. The flow-sheet designed is versatile enough to take care of these mineralogical differences. The suggested flow-sheet is schematically shown in figure 14 .

Taking into account the results obtained during semi pilot plant scale tests and recirculation of the streams as suggested in the flow-sheet, it should be readily feasible 


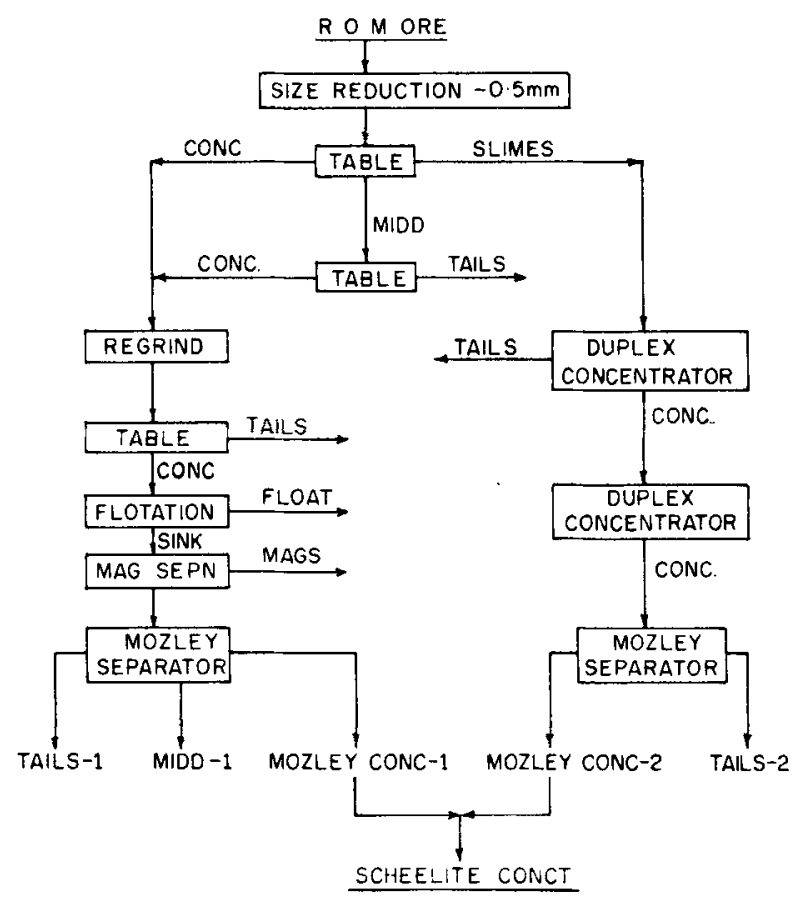

Figure 15. Flow-sheet followed in the IBM tests for the beneficiation of Khobna tungsten ore.

to obtain recoveries of $72-75 \%$ in the scheelite concentrate at the end of WHIMS stage with grades of 60 to $65 \% \mathrm{WO}_{3}$. After the final recleaner tabling the expected results are (i) a high grade marketable scheelite concentrate of $73-75 \% \mathrm{WO}_{3}$ grade at a recovery of $62-65 \%$, and (ii) a low grade concentrate of $10-12 \% \mathrm{WO}_{3}$ grade with a distribution of $10-15 \%$. In addition another low grade concentrate of wolframite is also feasible.

\subsection{IBM tests}

Indian Bureau of Mines have carried out batch as well as semi pilot plant scale tests on both oxidized $\left(0.22 \% \mathrm{WO}_{3}\right)$ and primary $\left(0.27 \% \mathrm{WO}_{3}\right)$ ore samples. The flow-sheet followed for the tests (BRGM-MECL Rept. 1991) is schematically shown in figure 15 and essentially involved processing on shaking tables after size reduction to $-500 \mu \mathrm{m}$ to obtain three products, a table concentrate, coarse table tails (middlings) and table slimes. The middlings are scavenged by tabling, after conditioning with Aerosol OT. The primary table concentrates and the scavenger concentrates are mixed, ground to all passing through $250 \mu \mathrm{m}$ screen, and retabled. The cleaner table concentrates are upgraded by sulphide flotation and magnetic separation. The nonmagnetic fractions are cleaned on Mozley mineral separator, to give a high grade scheelite concentrate (Mozley Conct. I). The primary table slimes are processed on Duplex concentrator in two stages (rougher and cleaner), and the concentrates further cleaned on Mozley mineral separator, to obtain a low grade second concentrate (Mozley Conct. II). In one of the tests size reduction to $-500 \mu \mathrm{m}$ was effected by crushing only avoiding grinding, in order to reduce high slime generation. The best results obtained with the primary and the oxidized samples are summarized in table 17. 
Table 17. IBM test results on Khobna ore (for flow-sheet see figure 15).

\begin{tabular}{|c|c|c|c|}
\hline Product & Weight $\%$ & $\mathrm{WO}_{3}$ Assay $\%$ & $\mathrm{WO}_{3}$ Dist. $\%$ \\
\hline \multicolumn{4}{|c|}{ Oxidized ore sample (feed assay $0.22 \% \mathrm{WO}_{3}$ ): } \\
\hline Mozley Conct. I & $0 \cdot 15$ & $73 \cdot 1$ & $49 \cdot 6$ \\
\hline Mozley Tails I & 0.12 & 3.5 & 1.9 \\
\hline Mozley Conct. II & 0.38 & $6 \cdot 0$ & $10 \cdot 3$ \\
\hline Feed & & $0 \cdot 22$ & \\
\hline \multicolumn{4}{|c|}{ Primary ore sample (feed assay $0.27 \% \mathrm{WO}_{3}$ ): } \\
\hline Mozley Conct. I & 0.21 & $72 \cdot 1$ & $56 \cdot 4$ \\
\hline Mozley Tails I & 0.04 & $4 \cdot 6$ & 0.6 \\
\hline Mozley Conct. II & 0.23 & $7 \cdot 0$ & 6.0 \\
\hline Feed & & 0.27 & \\
\hline
\end{tabular}

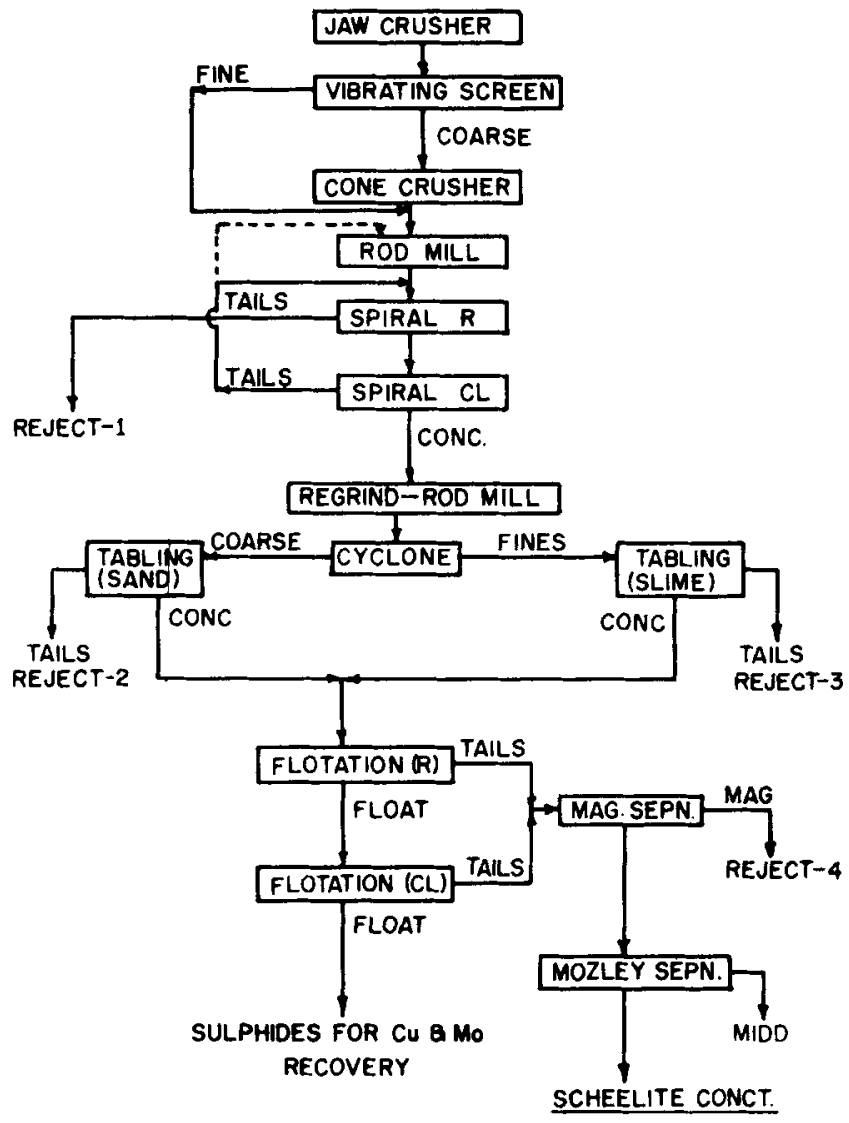

Figure 16. Industrial flow-sheet (schematic) suggested by IBM for the beneficiation of Khobna tungsten ore.

The sulphide concentrates obtained in the case of the oxidized ore yielded grades of $6.0 \% \mathrm{Cu}$ and $0.2 \% \mathrm{Mo}$, while those obtained with primary ore analyzed $11.0 \% \mathrm{Cu}$ and $0.8 \%$ Mo. 


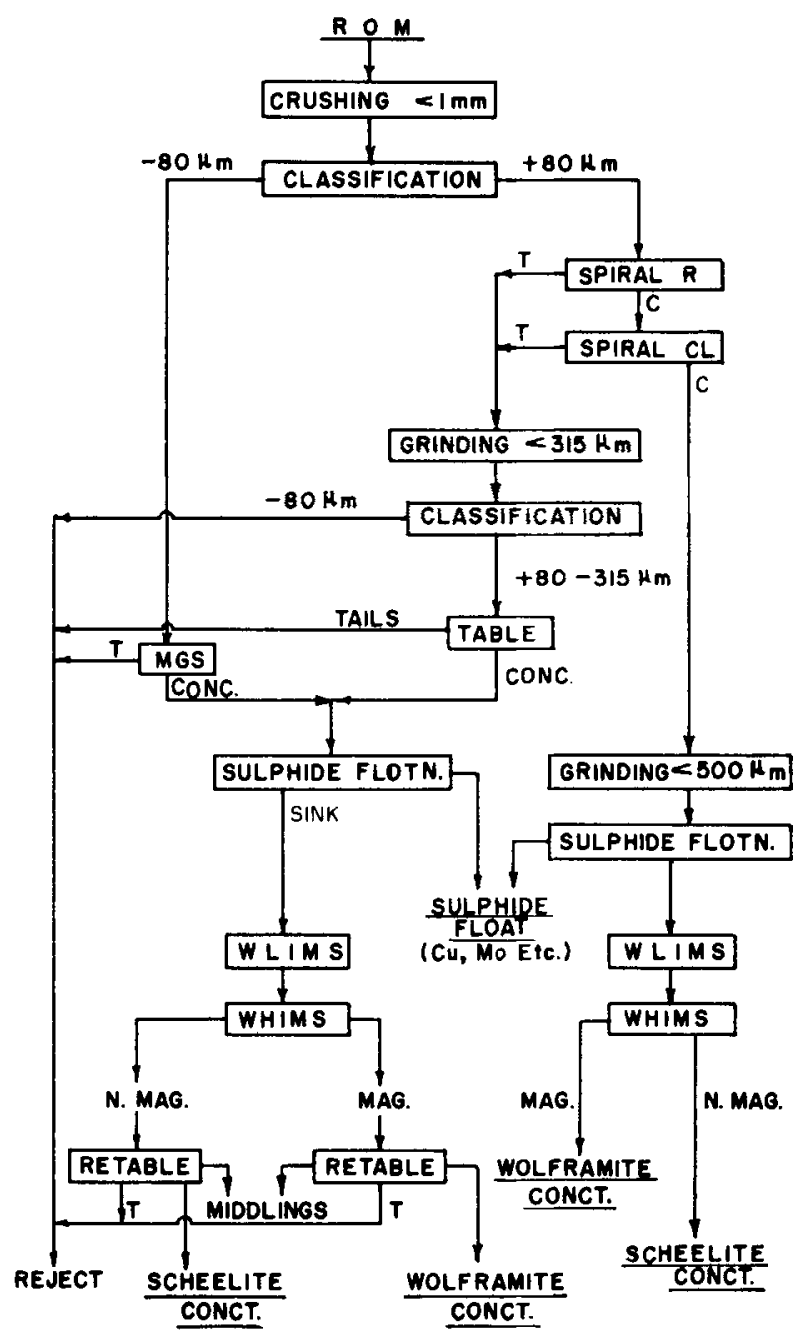

Figure 17. Flow-sheet followed in the BRGM semi pilot plant scale test for the beneficiation of Khobna tungsten ore.

Based on the semi pilot scale tests IBM have suggested an industrial flow-sheet for the beneficiation of the Khobna ore (BRGM-MECL Rept. 1991), which is schematically shown in figure 16. The projected efficiency of this flow-sheet is $55 \%$ and $62 \%$ recovery respectively for the oxidized and the primary ore, at $70 \% \mathrm{WO}_{3}$ grade.

\subsection{BRGM tests}

BRGM (France) also carried out semi pilot plant scale tests on one bulk sample each from the oxidized and the primary zone. The former analyzed $0.290 \% \mathrm{WO}_{3}$, $0.077 \% \mathrm{Cu}$ and $60 \mathrm{ppm} \mathrm{Mo}$, and the latter $0.214 \% \mathrm{WO}_{3}, 0.130 \% \mathrm{Cu}$ and $262 \mathrm{ppm} \mathrm{Mo}$. Besides scheelite (major) and wolframite (minor), small amounts of cuprotungstite is also observed to occur. The flow-sheet followed for semi pilot plant scale tests 
Table 18. BRGM test results on Khobna Ore.

\begin{tabular}{|c|c|c|c|}
\hline Product & Weight $\%$ & $\mathrm{WO}_{3}$ Assay $\%$ & $\mathrm{WO}_{3}$ Dist. $\%$ \\
\hline \multicolumn{4}{|c|}{ Oxidized ore sample (feed assay $0.29 \% \mathrm{WO}_{3}$ ): } \\
\hline $\begin{array}{l}\text { Final concentrate from } \\
\text { spiral circuit }\end{array}$ & $0 \cdot 144$ & $70 \cdot 37$ & $41 \cdot 34$ \\
\hline $\begin{array}{l}\text { Final concentrate from } \\
\text { scavenger circuit }\end{array}$ & $0 \cdot 015$ & $45 \cdot 60$ & 3.59 \\
\hline $\begin{array}{l}\text { Final concentrate from } \\
\text { primary fines circuit }\end{array}$ & $0 \cdot 038$ & 62.04 & $9 \cdot 56$ \\
\hline Combined concentrates & $0 \cdot 197$ & $66 \cdot 83$ & $54 \cdot 48$ \\
\hline $\begin{array}{l}\text { Combined high grade } \\
\text { middlings }\end{array}$ & $0 \cdot 107$ & $26 \cdot 59$ & $11 \cdot 98$ \\
\hline Total conct + middlings & $0 \cdot 304$ & $52 \cdot 69$ & $66 \cdot 46$ \\
\hline \multicolumn{4}{|c|}{ Primary ore sample (feed assay $0.214 \% \mathrm{WO}_{3}$ ): } \\
\hline $\begin{array}{l}\text { Final concentrate from } \\
\text { spiral circuit }\end{array}$ & $0 \cdot 154$ & 73.27 & $57 \cdot 93$ \\
\hline $\begin{array}{l}\text { Final concentrate from } \\
\text { scavenger circuit }\end{array}$ & 0.024 & $68 \cdot 00$ & $6 \cdot 54$ \\
\hline $\begin{array}{l}\text { Final concentrate from } \\
\text { primary fines circuit }\end{array}$ & 0.055 & $51 \cdot 94$ & $11 \cdot 47$ \\
\hline Combined concentrates & 0.233 & $69 \cdot 12$ & 75.94 \\
\hline $\begin{array}{l}\text { Combined high grade } \\
\text { middlings }\end{array}$ & 0.015 & $22 \cdot 94$ & $1 \cdot 82$ \\
\hline Total conct. + middlings & 0.248 & $66 \cdot 24$ & $77 \cdot 76$ \\
\hline
\end{tabular}

(BRGM-MECL Rept 1991) is schematically shown in figure 17. As can be seen, after size reduction to $-1 \mathrm{~mm}$, the ore is classified at $80 \mu \mathrm{m}$, the coarse stream is processed on spirals, and the spiral tailings after regrinding is scavenged on shaking tables. The primary slimes are processed on Mozley Multi Gravity Separator. The gravity pre-concentrates are upgraded successively by sulphide flotation, wet low intensity magnetic separation and wet high intensity magnetic separation. The test results are summarized in table 18.

Based on these results an industrial flow-sheet has been suggested by BRGM (BRGM-MECL Rept. 1991), which is schematically illustrated in figure 18. The process adopted is projected to have an efficiency to yield $65 \%$ and $70 \% \mathrm{WO}_{3}$ concentrate grades at $60 \%$ and $75 \%$ recoveries respectively from the oxidized and primary ore feeds.

\subsection{Discussion}

Tungsten in the Khobna ore occurs in the form of scheelite, with only minor values present in wolframite. An important observation made in the investigations by all the three laboratories is that the manner of initial size reduction has a critical role to play in obtaining optimum recovery of tungsten values. This is because, scheelite being highly brittle, gets easily over ground during size reduction, especially if close circuit ball milling is employed. In order to avoid excessive sliming of scheelite, both the BARC and BRGM flow-sheets suggest primary size reduction in rod mill, to all passing 


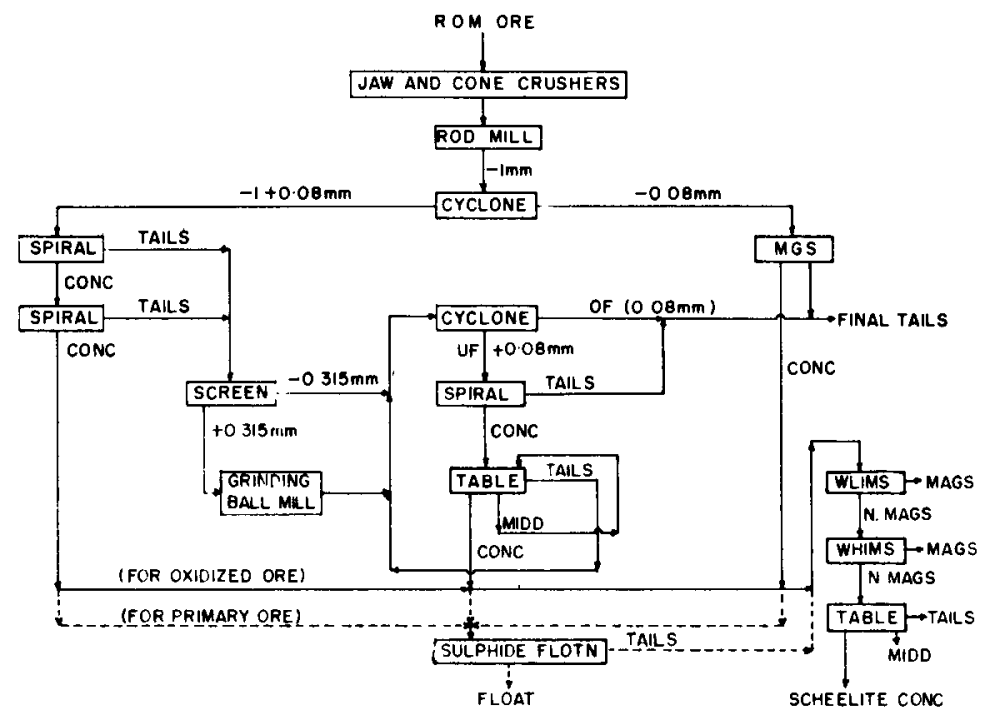

Figure 18. Industrial flow-sheet suggested by BRGM for the beneficiation of Khobna tungsten ore.

through $1 \mathrm{~mm}$, even though the optimum size of liberation of scheelite is about $150 \mu \mathrm{m}$. The BARC scheme prefers open circuit grinding in a peripheral discharge rod mill. The IBM flow-sheet suggests initial size reduction, in stages, to $-500 \mu \mathrm{m}$ size.

An integrated multistage flow-sheet, after classification at a suitable cut size is suggested by both BRGM and BARC, while IBM flow-sheet prefers classification during scavenging stage, after initial rougher spiralling of the ground material. Pre-concentration is by gravity methods, followed by upgradation by sulphide flotation and magnetic separation in two stages (low and high intensity). The semi pilot plant tests have clearly established the feasibility of obtaining high grade concentrates of $+70 \% \mathrm{WO}_{3}$, at reasonably high recoveries of 65 to $75 \%$, with the primary ore giving better recoveries. Copper, molybdenum and silver are shown to be potential byproducts of processing the Khobna ore, especially the primary ore.

While scheelite is the main tungsten-bearing mineral in the ore, some pockets of the ore do contain appreciable wolframite. It has been found difficult to upgrade wolframite. Wherever wolframite is present, it is inevitable to have a low grade concentrate containing the wolframite values, in the form of magnetic stream of WHIMS stage and this aspect is recognized in both BARC and BRGM flow-sheets.

\section{Burugubanda-Tapaskonda tungsten ore}

Tungsten-bearing quartz-rich pegmatite vein type deposits occur in East Godavari district of Andhra Pradesh. Two deposits have been delineated by National Mineral Development Corporation (Chatterjee et al 1987), one near Burugubanda village in Rampachodavaram Taluk and the other at Tapaskonda near Village Addatigala in Yerravaram Taluk. Wolframite occurs in lit-par-lit quartz-pegmatite veins hosted in graphite-gneiss belonging to the Khondalite suite of rocks. Wolframite occurs both in the quartz veins and in the host graphite-gneiss. 
Table 19. Mineralogical composition of Burugubanda tungsten ore (BARC Test Sample).

\begin{tabular}{lc}
\hline Mineral & Wt. per cent \\
\hline Quartz and kaolinized felspar & $90 \cdot 0$ \\
Graphite & $6 \cdot 0$ \\
Garnet & $1 \cdot 5$ \\
Sillimanite, topaz, zircon and monazite & $0 \cdot 5$ \\
Opaques (other than graphite) & $2 \cdot 0$ \\
Wolframite & $0 \cdot 13$ \\
Rutile and ilmenite & $0 \cdot 37$ \\
Hematite and other iron oxides & $1 \cdot 30$ \\
Sulphide minerals & $0 \cdot 20$ \\
Total & $100 \cdot 0$ \\
\hline
\end{tabular}

As in the case of Khobna, BRGM, IBM and BARC have carried out bench and semi pilot plant scale tests on representative sample of the ore from Burugubanda, collected and made available by NMDC. The results of BARC tests are described in detail here, while those of IBM and BRGM are discussed in brief.

\subsection{BARC test results}

Tests were carried out on a 5 tonne representative sample of the ore. Megascopically the ore contained two major lithological units (Sunilkumar and Rao 1991): (i) quartzkaolinized felspar-graphite schist and (ii) quartz veins and lenses with minor altered felspar. The graphite-gneiss/schist is an aphanetic lepidoblastic medium-grained rock, a schistocity being imparted by the sheaf like aggregates of graphite flakes. Felsparquartz veinlets and quartz lenses of varying size occur along the schistocity of planes of the gneissic rock. Graphite and quartz are the major constituents, with minor amounts of altered felspar, garnet, ore minerals, and traces of sillimanite, topaz, zircon and monazite. The ore minerals identified, besides wolframite, are rutile, ilmenite, magnesiochromite, hematite, lepidocrocite, goethite, and sulphides-pyrite, marcasite, pyrrhotite, chalcopyrite and sphalerite.

Wolframite has widely varying habit and grain size, in the form of coarse pinching and swelling veins of one to four $\mathrm{cm}$ in width, narrow veinlets of one to two $\mathrm{mm}$ width and as medium to fine sized disseminations in the quartz veins as well as graphite gneiss. Two types of wolframite grains are observed, one in the form of equidimensional grains and grain aggregates, and the other in the form of fine sheaf-like crystalline aggregates. Rutile is the nigrine variety (identified by BRGM), and is a characteristic and striking constituent of this ore. Quantitative mineralogical analysis of a representative sample of the ore is given in table 19.

Replicate chemical analysis of four separately drawn feed samples gave a mean $\mathrm{WO}_{3}$ assay of $0.092 \%$ with a sample standard deviation of $0.008 \%$. The fixed carbon content was $5.0 \%$.

Liberation analysis showed that wolframite is coarsely liberated. A sample crushed to all passing through 8 \# contained about $61 \%$ liberated wolframite. In sizes finer than $210 \mu \mathrm{m}(65 \#)$ wolframite was almost completely liberated except for few very fine 
inclusions within quartz, accounting for about $2 \%$ of the overall distribution, which was considered irrecoverable. Work Index determined by Bond's method was $11.59 \mathrm{kwh}$ per short ton or $12.77 \mathrm{kwh}$ per metric ton.

9.1a Beneficiation tests: During batch beneficiation tests (Padmanabhan et al 1991; Rao et al 1992) the following strategies were adopted:

1. Separation of quartz-rich pegmatitic pieces from the rest (graphite-rich) by handsorting, and processing the two streams separately.

2. Classification of the crushed ore into different fractions and processing them separately.

3. Grinding the crushed ore in a rod mill, flotation of graphite from the ground ore and processing the flotation tailings for the recovery of wolframite.

4. Suitable sizing of the crushed ore into coarse and fines, processing the coarse stream by jigging and the fines stream by tabling after flotation of graphite.

Strategy 1: The details of the experiment carried out is schematically shown in figure 19. The hand sorting was carried out on $+6 \mathrm{~mm}$ fraction of the as received material, after reducing in size the coarse boulders manually. The hand-sorted quartzrich fraction was crushed to all passing through $12.5 \mathrm{~mm}$ screen, then screened successively on $6 \mathrm{~mm}$ and $28 \#$ screens. The $+6 \mathrm{~mm}$ and the $+28 \#$ streams are processed on jigs, while the -28 fraction was treated on shaking tables. The graphite-rich initial fines $(-6 \mathrm{~mm})$ was screened through $28 \#$ screen, and the coarser and the finer fractions are processed by jigging and tabling routes respectively, the latter after flotation of graphite. The graphite-rich hand-sorted coarse was reduced in size to -28 \# by grinding in a rod mill, and processed by shaking tables after graphite flotation. The material balance at the various pre-concentration stages are included in figure 19.

While these concentrates are not marketable beneficiation products, they nevertheless give a precise idea about the grade and recoveries that are feasible to be achieved during pre-concentration. It should also be possible to improve the recovery by recirculation of various middling products. The main contaminants in the jig concentrates were quartz, rutile, sulphides, iron oxides and garnet. The table concentrates had also similar mineralogical composition, except that the proportions of garnet and rutile were much higher. While quartz and garnet can be separated by high tension separation, iron oxides, pyrite and pyrrhotite can be removed by magnetic separation.

It was also noticed that while the jigging operations exhibited very high selectivity in respect of separation of wolframite, in the tabling operations the selectivity was rather poor, mainly because of the presence of high amounts of minerals like rutile and garnet.

Strategy 2 (Classification of the crushed ore followed by separate processing of the streams): In the previous experiment it was seen that during initial crushing, the wolframite values mainly remain in the coarser size fractions and that these are amenable to beneficiation by jigging. In this experimental scheme the ore feed crushed to all pass through $6 \mathrm{~mm}$ screen was classified into three size fractions, namely, $-6+1 \mathrm{~mm},-1+0.420 \mathrm{~mm}$ and $-0.420 \mathrm{~mm}$ fractions. The first two size fractions were processed by jigging, while the last fraction was subjected to graphite flotation first, and the flotation tails tabled to recover wolframite. The test strategy along with material balance at various pre-concentration stages is schematically shown in figure 20 . Here also good selectivity was obtained during the jigging stage. 


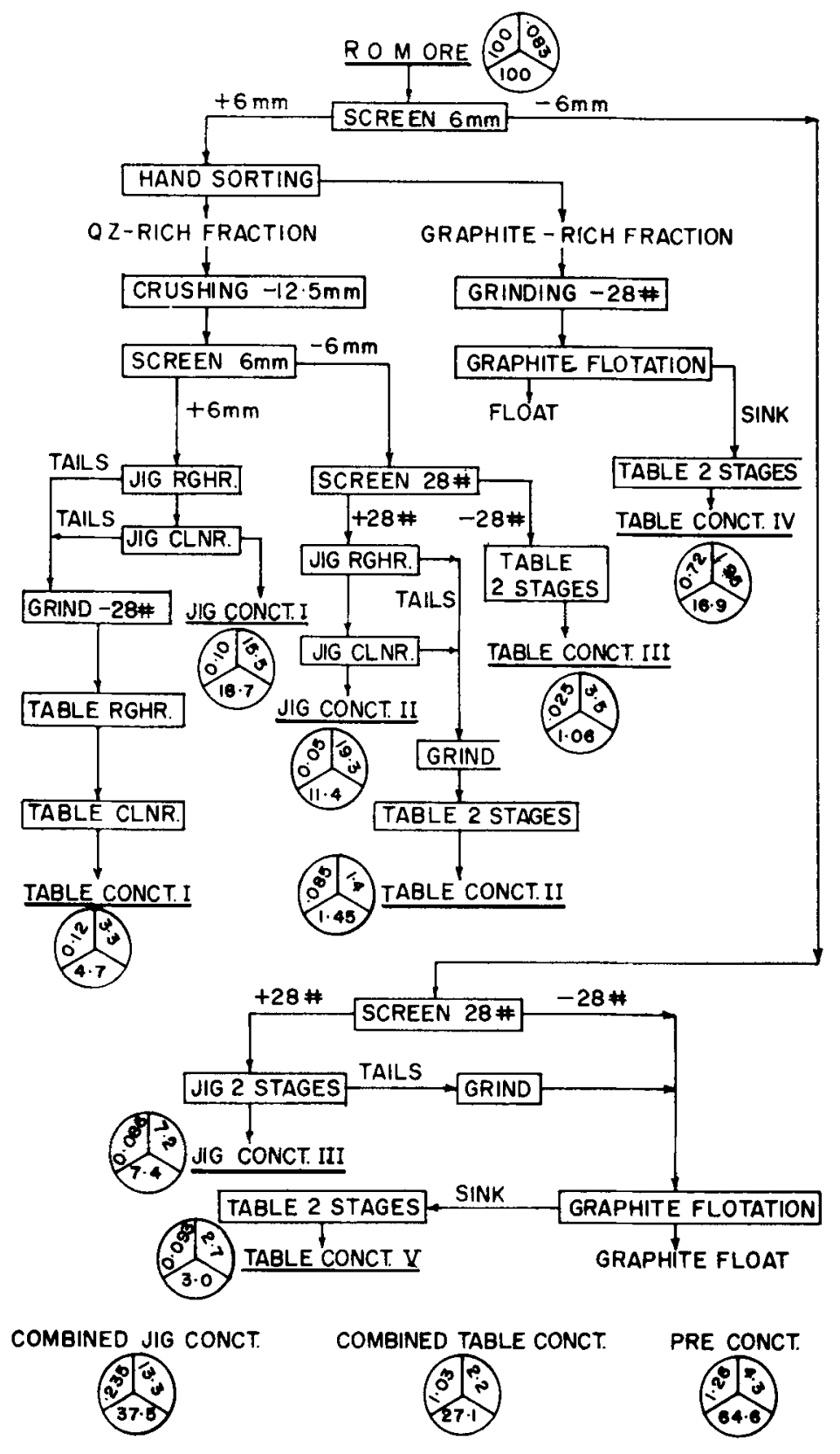

Figure 19. Flowchart of BARC semi pilot plant scale test on beneficiation of Burugubanda tungsten-graphite ore - Strategy 1 , along with metallurgical material balance.

Strategy 3 (Grinding of the ore followed by graphite flotation and wolframite recovery from flotation tailings): This flow-sheet was primarily aimed at optimal recovery of graphite, with wolframite as a byproduct. Here the ore crushed to all passing through $6 \mathrm{~mm}$ was ground in a closed circuit pilot plant rod mill. Graphite from the ground ore was floated using kerosene as collector, pine oil as frother and sodium silicate as 


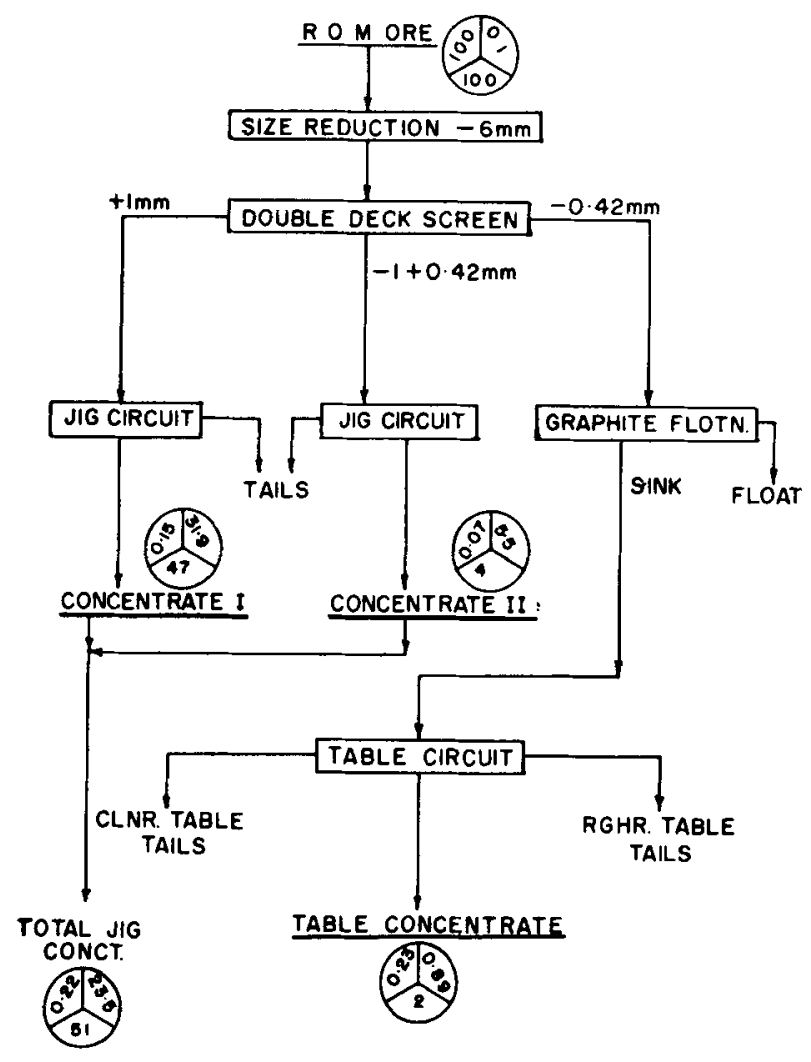

Figure 20. Flowchart of BARC semi pilot plant scale test on beneficiation of Burugubanda tungsten-graphite ore-Strategy 2 , along with metallurgical material balance.

depressant for the silicates. In the rougher float stage nearly $99 \%$ of graphite could be floated at a grade of $21.5 \%$ fixed carbon (F.C.). The float was cleaned three times, which improved the grade to $41 \%$ F.C. The rougher tails and the three cleaner tails are mixed and processed on shaking tables. The table concentrate assayed $9 \cdot 2 \% \mathrm{WO}_{3}$ at a recovery of $28 \%$ only. The fine grinding of the sample (about $50 \%-200 \#$ ) perhaps resulted in over grinding of wolframite, leading to its lower recovery.

In an alternate scheme of the experiment, generation of excessive slimes was avoided by open circuit grinding, and an attempt was made to improve the efficiency of gravity pre-concentration by classifying the ground ore into coarse and fine fractions and processing the two fractions separately, after flotation of graphite, as was carried out in the previous experiment. The flotation tailings of the coarser stream was pre-concentrated on spirals followed by tables, while the fines stream was processed by two-stage tabling circuit. The classification was carried out on CTS stationary wet screens, at an effective $d_{50}$ cut size of $135 \mu \mathrm{m}$. The flow-sheet followed is schematically shown in figure 21 which also includes material balance at various stages.

Even though the results are better compared to the previous test without classification, they are still not satisfactory.

Strategy 4 (Separation of coarse wolframite by jigs and fine wolframite by spirals and tables after graphite flotation): In this scheme of experiment, schematically shown in 


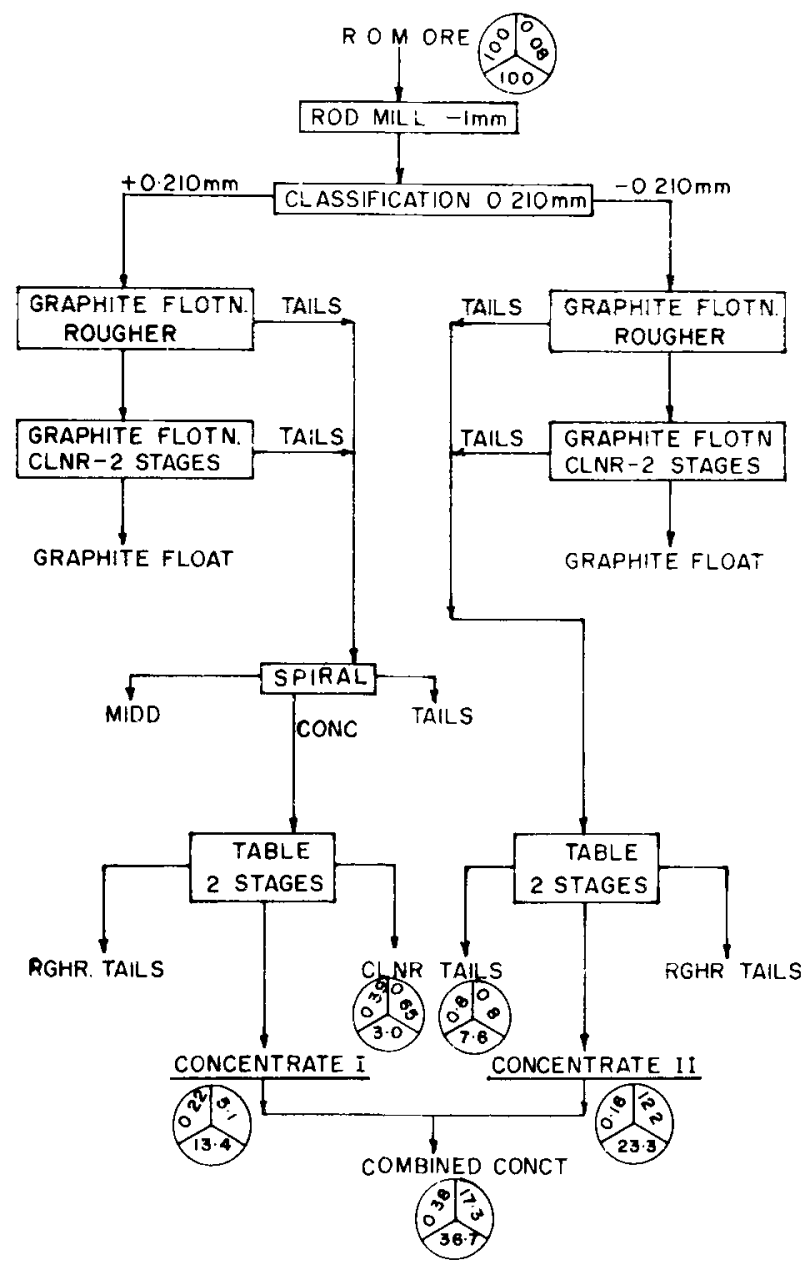

Figure 21. Flowchart of BARC semi pilot plant scale test on beneficiation of Burugubanda tungsten-graphite ore -Strategy 3, along with metallurgical material balance.

figure 22, Wu Weisun's (1982) philosophy of "the earlier recovered, the more recovered" was incorporated. The strategy was to recover tungsten minerals early at as coarse size as possible in order to prevent sliming or over-grinding. The process involved stage crushing the sample to $-6 \mathrm{~mm}$ size, followed by screening at $16 \#$. The screen oversize material was processed on mineral jigs in a multistage operation involving a rougher and two cleaner stages. The tails from the rougher and the two cleaner jigs were ground in a rod mill circuit to get a product all finer than $16 \#$. This was mixed with the original $-16 \#$ material and classinied in a stationary CTS screen at a $d_{50}$ cut size of about $120 \mu \mathrm{m}$. The CTS coarse and fines streams were processed in two identical parallel schemes, graphite flotation followed by spiralling and tabling of the flotation tails. Two large scale tests were carried out following this flow-sheet; however the second test was confined to the jigging stage only. The results are summarized in figure 22 and table 20 respectively.

The results show good recovery from the coarse stream in the jig circuit, stage recovery being about $55 \%$, giving a medium grade concentrate of about $30-35 \% \mathrm{WO}_{3}$. 


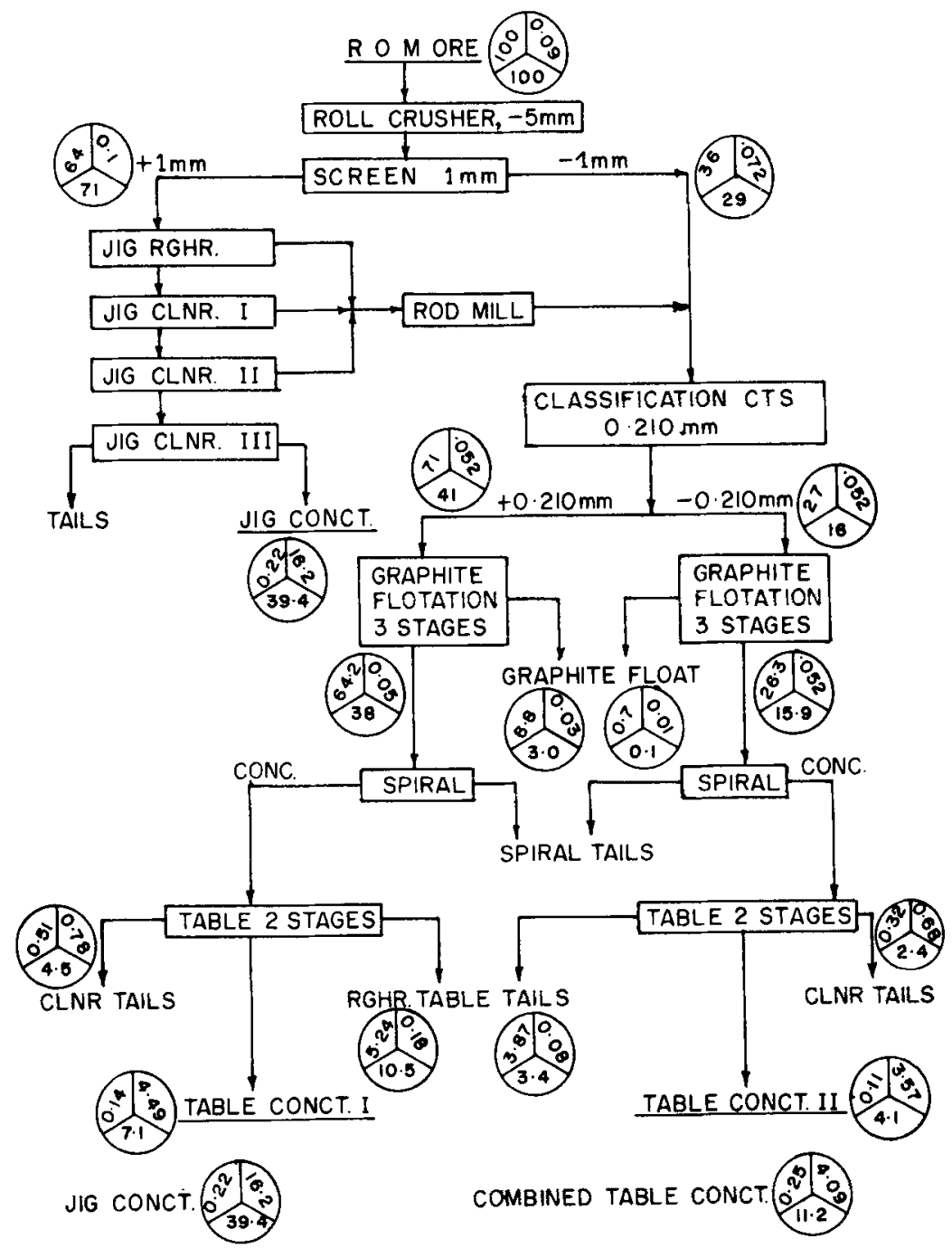

Figure 22. Flowchart of BARC semi pilot plant scale test on beneficiation of Burugubanda tungsten-graphite ore-Strategy 4 , along with metallurgical material balance.

Table 20. Results of BARC Test No. 2 on Burugubanda ore following strategy 4 (for flow-sheet see figure 22).

\begin{tabular}{lccc}
\hline Process streams & Weight $\%$ & WO $_{3}$ assay $\%$ & WO $_{3}$ dist. \% \\
\hline Feed & $100 \cdot 0$ & 0.134 & $100 \cdot 0$ \\
+16 mesh & 60.6 & 0.15 & 67.7 \\
-16 mesh & $39 \cdot 4$ & 0.11 & 32.3 \\
Cleaner jig conct. I (Hutch) & 0.03 & 30.21 & 7.6 \\
Cleaner jig conct. II (Bed) & $0 \cdot 11$ & 36.20 & 30.5 \\
Jig conct. III & 0.12 & 2.94 & 2.6 \\
$\quad$ (scavenging jig tails) & & & $59 \cdot 3$ \\
Combined jig tails \& -16 mesh & 99.7 & 0.075 & \\
\hline
\end{tabular}


Scope exists for improving the recovery by about $5 \%$ by recirculation of various middling streams in a continuous circuit. Recovery and grade obtained from the fines stream in the spiral-table circuit is poor, a feature observed in all the experiments under different schemes of processing. One of the reasons for the poor performance is the graphite coating onto the wolframite surface, affecting their hydrodynamic properties during thin film concentration prevailing in spirals and tables. Nevertheless with optimization and recirculation of middling streams it should be possible to improve both grade and recovery to about $12-15 \%$ and $30-35 \%$ (stage) respectively. The results also underscore the necessity to recover the tungsten values at as coarse size as possible and to avoid unnecessary overgrinding.

9.1b Upgradation of the gravity pre-concentrates: The main contaminants in the jig and table concentrates were garnet, rutile (nigrine variety), iron oxides, sulphides (pyrite, pyrrhotite and marcasite), zircon, monazite and quartz. Batch laboratory tests showed that while bulk of garnet and quartz could be separated by high tension separation, low intensity magnetic separation removed pyrrhotite and part of iron oxide minerals (altered magnetite). High intensity magnetic separation removed pyrite. remaining quartz and zircon in the nonmagnetic stream. Removal of rutile and part of the iron oxide minerals proved problematic and a multistage magnetic separation with repeated recirculation after careful size classification is necessary to reduce these contaminants. If the sulphide mineral content is high, they can be removed by flotation, before high tension and magnetic separation stages.

9.1c Byproducts: Graphite is the most important byproduct in the case of Burugubanda ore, which assays 5 to $7 \%$ fixed carbon. In some parts of the ore body it has the potential to be the main product, and tungsten byproduct. In the tests involving flotation of graphite, rougher floats assayed 25 to $30 \%$ F.C. carrying $>90 \%$ distribution. Two stages of cleaning by flotation improved the grade to 40 to $45 \%$ F.C. at about $85 \%$ overall recovery. Further cleaner stages of flotation with regrinding could upgrade the product to 70 to $75 \%$ F.C. To produce high grade concentrate of graphite, chemical leaching with HF was found necessary, which could improve the product to $90-92 \%$ F.C. Rutile (nigrine variety) is another potential byproduct of beneficiation of Burugubanda ore.

9.1d Industrial flow-sheet for beneficiation: Based on the results of several large scale tests, an industrial flow-sheet has been suggested (Padmanabhan et al 1991), which essentially follows the strategy 4 discussed above. The flow-sheet along with projected mass balance is given in figure 23. A recommended upgradation flow-sheet is illustrated in figure 24.

\subsection{BRGM test results}

BRGM carried out semi pilot plant scale tests on a 5 tonne representative sample of the ore from Burugubanda, analyzing $0 \cdot 1 \% \mathrm{WO}_{3}$ and $7 \cdot 6 \%$ fixed carbon. The flow-sheet adopted by BRGM (BRGM-MECL Rept. 1990; Save and Conil 1990) is schematically shown in figure 25 . The procedure involved (i) crushing the ore to $-1 \mathrm{~mm}$, (ii) screening at $315 \mu \mathrm{m}$, (iii) graphite flotation and spiral pre-concentration of the 


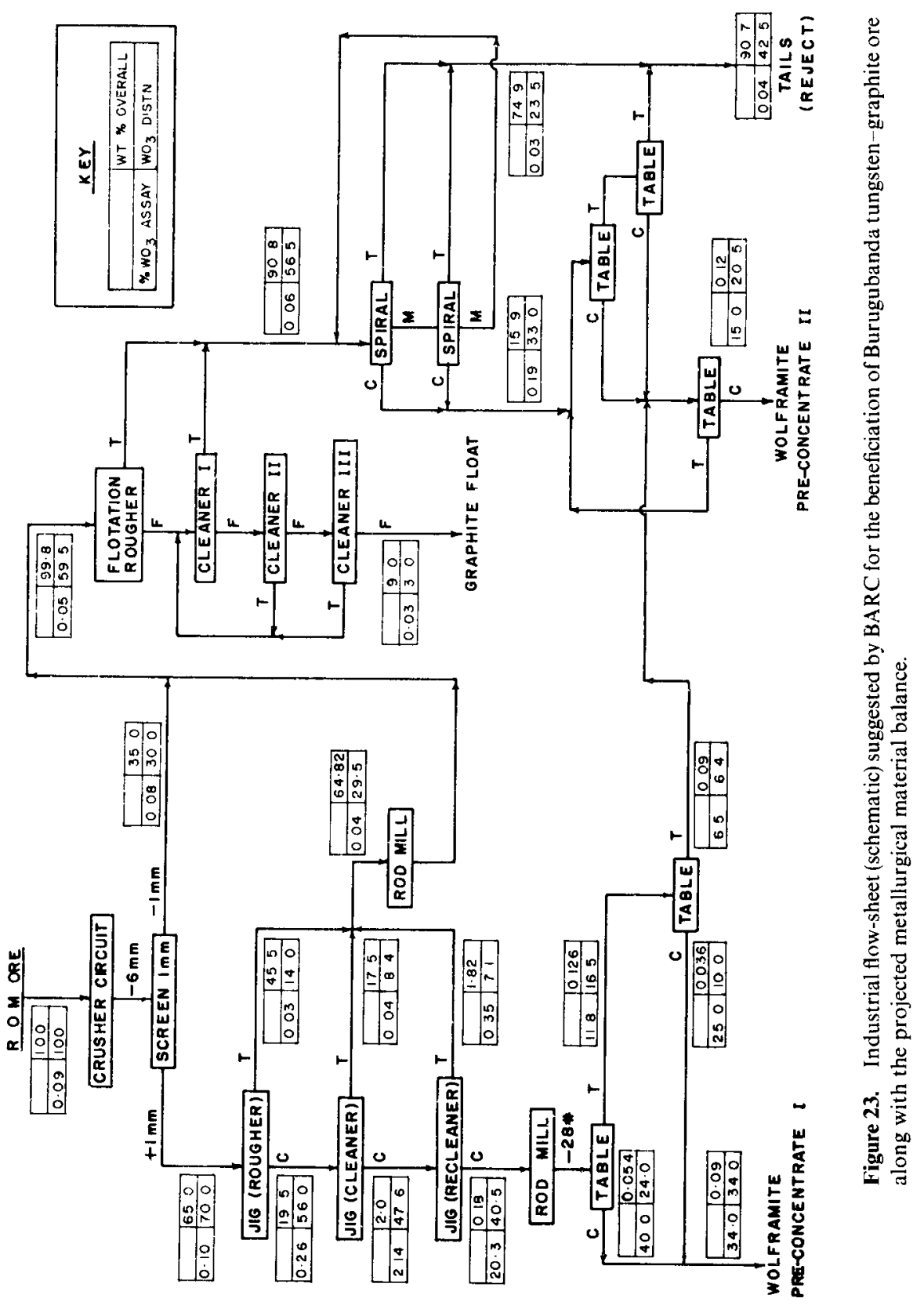




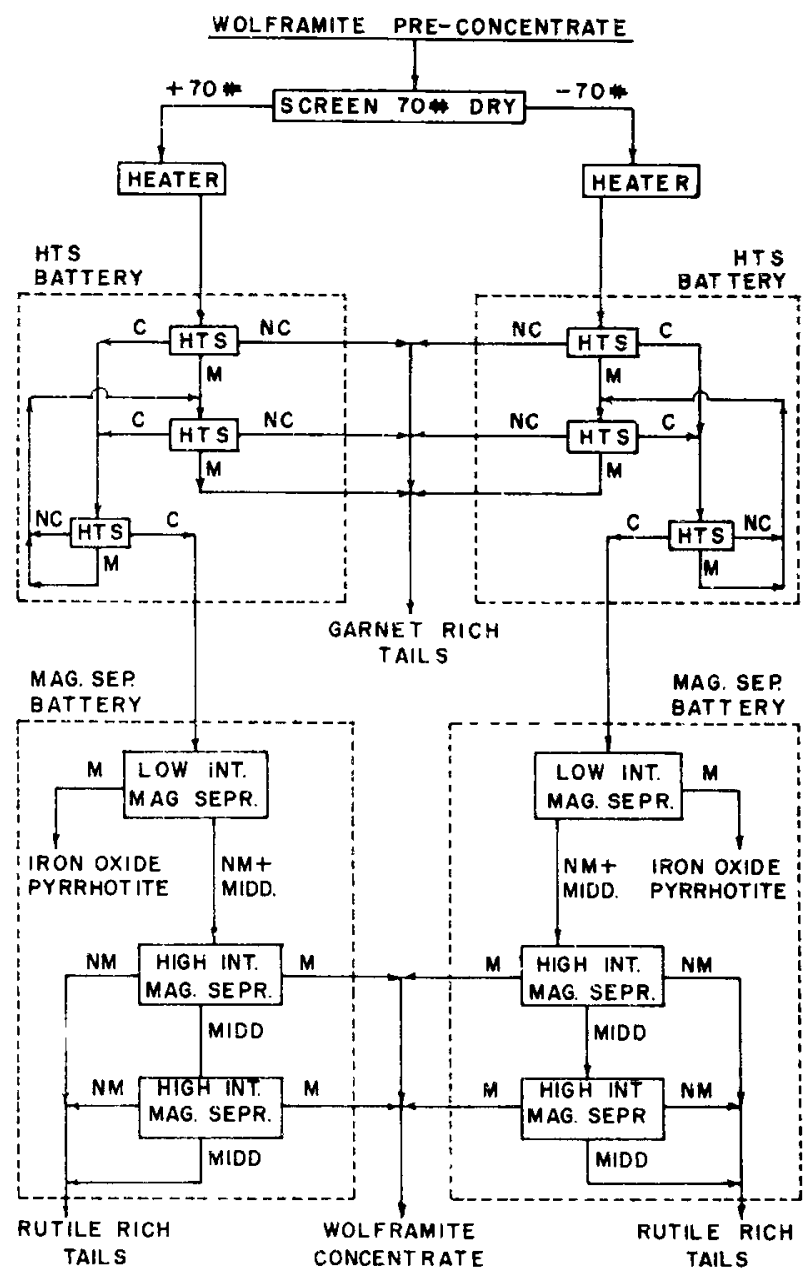

Figure 24. Flow-sheet recommended by BARC for the upgradation of wolframite preconcentrate from Burugubanda.

$+315 \mu \mathrm{m}$ fraction, (iv) graphite flotation and classification of the $-315 \mu \mathrm{m}$ fraction at $63 \mu \mathrm{m}$, followed by table pre-concentration of the $+63 \mu \mathrm{m}$ fraction, and $(v)$ preconcentration of the $-63 \mu \mathrm{m}$ fraction on the Mozley Multi Gravity Separator (MGS).

The material balance of the test at the end of the pre-concentration stage, is given in table 21 .

Thus $52 \%$ of the tungsten values were recovered in various pre-concentrates at an average grade of $2.85 \% \mathrm{WO}_{3}$. An additional $11 \%$ of the values were contained in various middlings at an average grade of $0.34 \% \mathrm{WO}_{3}$.

Two routes were tried for upgrading the pre-concentrates: (i) gravimetric separation with Mozley Multi Gravity Separator after grinding the pre-concentrates to $80 \mu \mathrm{m}$, and (ii) electrostatic separation. Magnetic separation did not yield any appreciable upgradation mainly due to the presence of nigrine. The upgradation achieved by the two routes are given in table 22 . Thus if a high grade concentrate is desired 


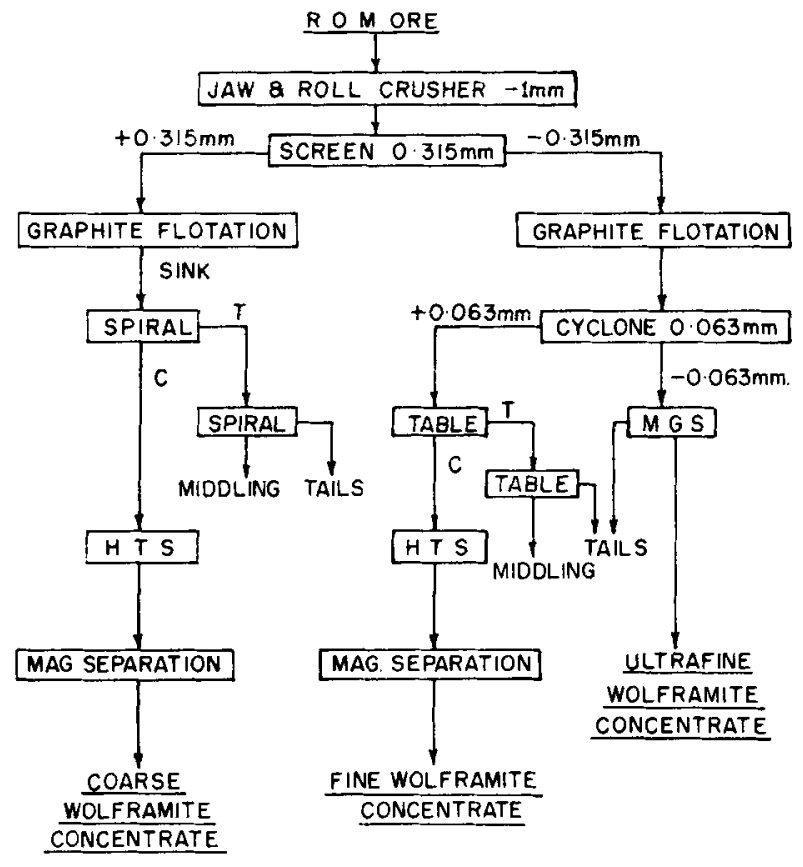

Figure 25. Flowchart of BRGM semi pilot plant scale test on the beneficiation of Burugubanda tungsten-graphite ore.

Table 21. Results of BRGM semi pilot plant tests on Burugubanda ore (for flow-sheet see figure 25).

\begin{tabular}{lccc}
\hline Pre-concentrate stream & Weight $\%$ & WO $_{3}$ grade $\%$ & WO $_{3}$ rec. \% \\
\hline$+315 \mu$ m spiral preconcentrate & 0.63 & 2.33 & 17.28 \\
$-315+63 \mu$ m table preconct. & 0.67 & 2.85 & 22.54 \\
$-63 \mu$ m MGS preconct. & 0.26 & 4.10 & 12.35 \\
Total pre-concentrate & 1.56 & 2.85 & 52.17 \\
Spiral middlings & 2.20 & 0.37 & 9.47 \\
Table middlings & 0.48 & 0.25 & 1.41 \\
Total gravity middlings & 2.68 & 0.35 & 10.88 \\
Spiral tailings & 31.43 & 0.028 & 10.26 \\
Table tailings & 27.50 & 0.019 & 6.06 \\
MGS tailings & 14.83 & 0.050 & 8.03 \\
Final tailings & 73.36 & 0.029 & 24.39 \\
$+315 \mu$ m graphite float & 9.62 & 0.044 & 4.97 \\
$-315 \mu$ m graphite float & 12.38 & 0.046 & 7.63 \\
Combined graphite conct. & 22.00 & 0.045 & 12.60 \\
Feed & 100 & 0.085 & 100 \\
\hline
\end{tabular}

the recovery is only of the order of $15 \%$; on the other hand at a low grade product of about $6 \% \mathrm{WO}_{3}$, a high recovery of 40 to $45 \%$ is possible. The industrial flowsheet recommended by BRGM (BRGM-MECL Rept. 1990) is schematically shown in figure 26 . 
Table 22. Results of concentrate upgradation (BRGM test).

\begin{tabular}{lrrr}
\hline Product & Weight $\%$ & WO $_{3}$ grade & WO $_{3}$ rec. \% \\
\hline A. MGS route: & & & \\
Final concentrate & 0.02 & 54.60 & 15.07 \\
Low grade middlings & 1.54 & 2.18 & 37.10 \\
Total pre-concentrate & 1.56 & 2.85 & 52.17 \\
B. HTS route (in three stages): & & & \\
Final concentrate & 0.63 & 5.76 & 42.66 \\
Low grade middlings & 0.93 & 0.88 & 9.51 \\
Total pre-concentrate & 1.56 & 2.85 & 52.17 \\
\hline
\end{tabular}

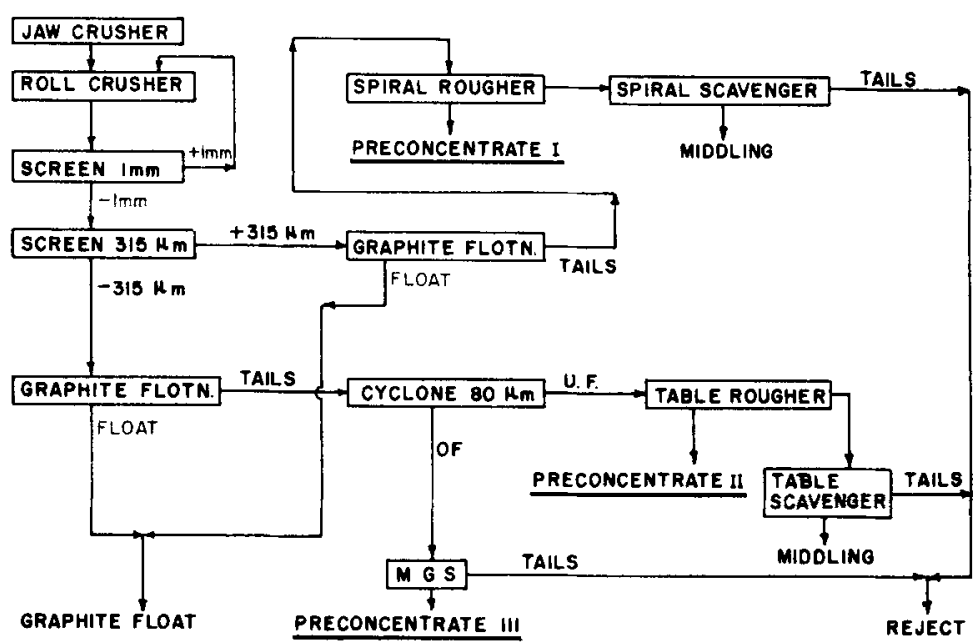

Figure 26. Industrial flow-sheet (schematic) suggested by BRGM for the beneficiation of Burugubanda tungsten graphite ore.

\subsection{IBM test results}

Indian Bureau of Mines also carried out tests on bulk scale on the beneficiation of tungsten-graphite ore from Burugubanda. The sample investigated by them (Ramanamurthy et al 1990), however, was of better tenor compared to the samples tested by both BARC and BRGM. The sample analyzed $0.21 \% \mathrm{WO}_{3}$ and $7 \%$ fixed carbon. After several tests, IBM arrived at an optimal flow-sheet for the beneficiation of the Burugubanda ore, keeping in view the recovery of both wolframite and graphite. Figure 27 schematically illustrates the flow-sheet suggested by them as well as the metallurgical results of the test.

While a mixture of kerosene and $\operatorname{MIBC}(0.026 \mathrm{~kg} / \mathrm{t}$ each $)$ was used during rougher flotation of graphite, MIBC $(0.007 \mathrm{~kg} / \mathrm{t})$ was used during cleaner flotation stages. However the grade of graphite concentrate could not be improved even after seven regrinding and flotation stages due to fine interlocking with silicate minerals. Poor recovery of tungsten values is attributed to loss in slimes which could not be recovered. Upgradation of the concentrate also could not be achieved due to the presence of iron oxides, having similar magnetic susceptibility as wolframite. 


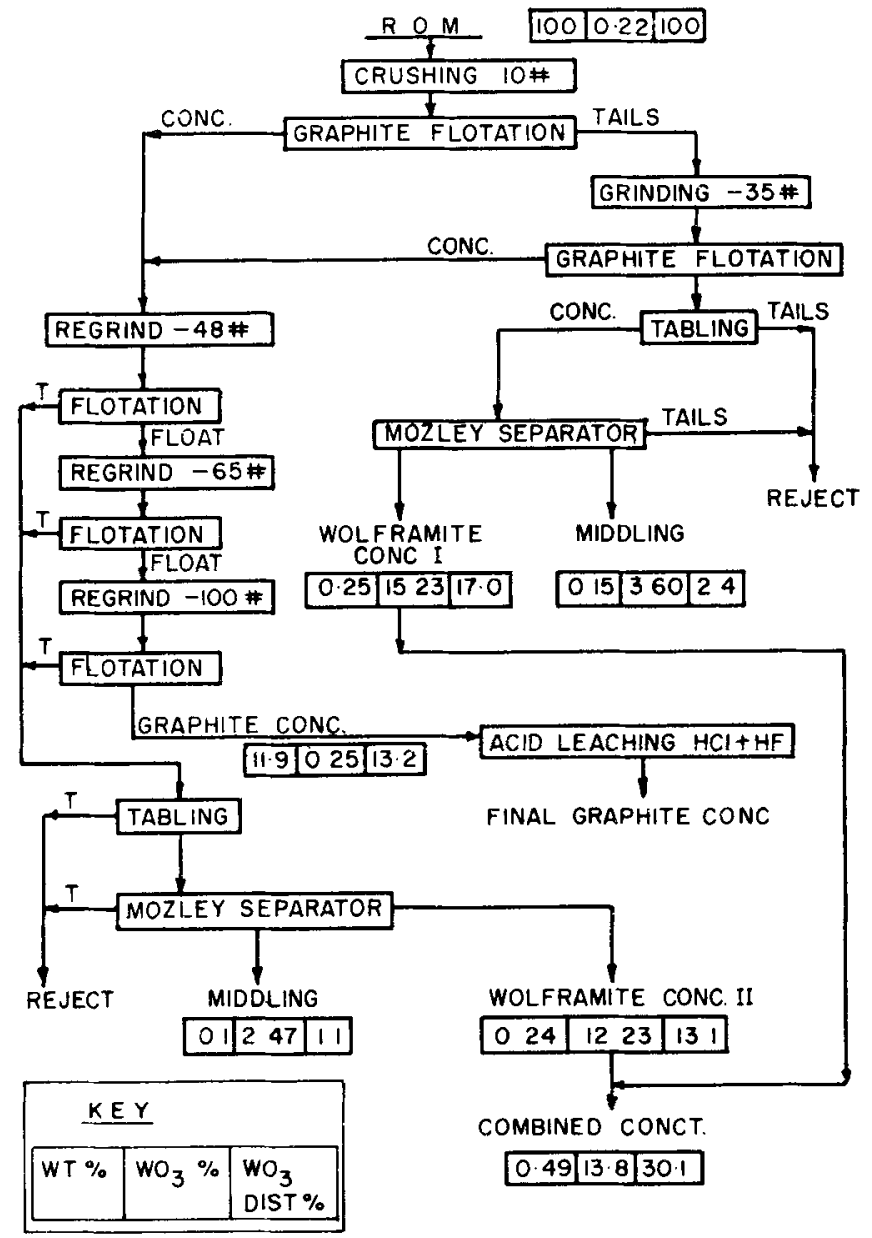

Figure 27. Flow-sheet (schematic) suggested by IBM for the beneficiation of Burugubanda tungsten-graphite ore, along with metallurgical material balance.

\subsection{Discussion}

The Burugubanda-Tapaskonda tungsten deposit, though of a low tenor, is reported to be extensive. The NMDC estimation puts the total reserves of the order of 16500 tonnes of contained $\mathrm{WO}_{3}$. The economics of tungsten recovery is linked to the recovery of marketable grade concentrates of graphite, which perhaps will be the main product. Graphite concentrates of 60-70\% fixed carbon can be readily obtained after 2-3 stages of flotation with regrinding steps in between. Grades of $>90 \%$ fixed carbon can be obtained only after chemical leaching.

The liberation data available indicate that nearly $60 \%$ of the wolframite values are liberated at a fairly coarse size, and available test results indicate that better recoveries are obtained only from coarse sizes. Any finer grinding results, not only in sliming of brittle wolframite, but also its getting coated with graphite, affecting its recovery in subsequent steps of beneficiation, both gravity and flotation. It is no surprise, therefore, that the best results are obtained in the BARC flow-sheet, which envisages initial size 
reduction to $-6 \mathrm{~mm}$ only, and resorts to jigging to recover values occurring in the coarser sizes.

\section{Scheelite bearing gold tailings from Kolar}

The occurrence of minor tungsten in the form of scheelite in the gold ores of Kolar is well known, and the dumps of gold tailings accumulated over the years is recognized as an important resource base of this strategic material. The Balaghat and Walker's dumps are two of the important dumps, containing an estimated total resources of 720 tonnes of $\mathrm{WO}_{3}$ (Anon 1985). The former averages $0.05 \% \mathrm{WO}_{3}$ and the latter $0 \cdot 18 \%$. Other low grade tailing dumps containing 0.01 to $0.03 \% \mathrm{WO}_{3}$, accounting for a resource of 3300 tonnes are also reported. Extensive studies have been carried out on the recovery of scheelite from the Walker's dumps by IBM as well as BARC.

\subsection{IBM studies}

Indian Bureau of Mines carried out bench and pilot plant scale studies on the recovery of scheelite from the Walker's and Balaghat dumps. Based on the flow-sheet developed by IBM (figure 28) (IBM Rept. 1977), a pilot plant each to treat 50 tonnes of Walker's tailings and 200 tonnes of Balaghat tailings were set up in 1980 (Anon 1988). However the actual recoveries obtained at these plants were much below the design figures, which were attributed to the changed granulometry of the feed to the plants. Subsequently recovery operations from the Balaghat tailings were discontinued. Attempts were also made to recover values in the 'slimes' by the use of Bartles machines BMS and CBC, however these were not particularly successful (Anon 1988).

The process adopted in the Walker's pilot plant, after optimization, consists of a complex spiral-tabling gravity circuit for pre-concentration (Anon 1988). The tailings are first processed on primary spirals, and the concentrates tabled. The primary spiral tails are scavenged on secondary spirals, and the secondary spiral concentrates are tabled separately. The tails of primary and secondary tabies are dewatered on a hydrocyclone, and the cyclone underflow scavenged again on primary and secondary scavenger spirals, and the respective concentrates are tabled. The middlings of the primary, secondary and scavenger tables are retabled for additional recovery. The table concentrates are mixed and processed by reverse flotation followed by magnetic separation of flotation sink to obtain scheelite concentrate as the nonmagnetic stream. The plant tailings are deslimed on hydrocyclone, and the cyclone overflow containing slimy scheelite particles are processed on Bartles machines (BMS and CBC) for additional recovery. This stream, however, produces only lean grade concentrates.

\subsection{BARC studies}

During mid eighties BARC investigated the reasons for the low recovery of scheelite at the BGML pilot plant and the means of improving the recovery (Shukla et al 1983, 1985). The samples studied by BARC assayed $0 \cdot 1$ to $0 \cdot 14 \% \mathrm{WO}_{3}$. Size analysis showed that $50-65 \%$ of $\mathrm{WO}_{3}$ values are distributed in $45-50 \%$ weight of -200 material, and it is this high distribution in fines that poses the problem in efficient recovery of scheelite 


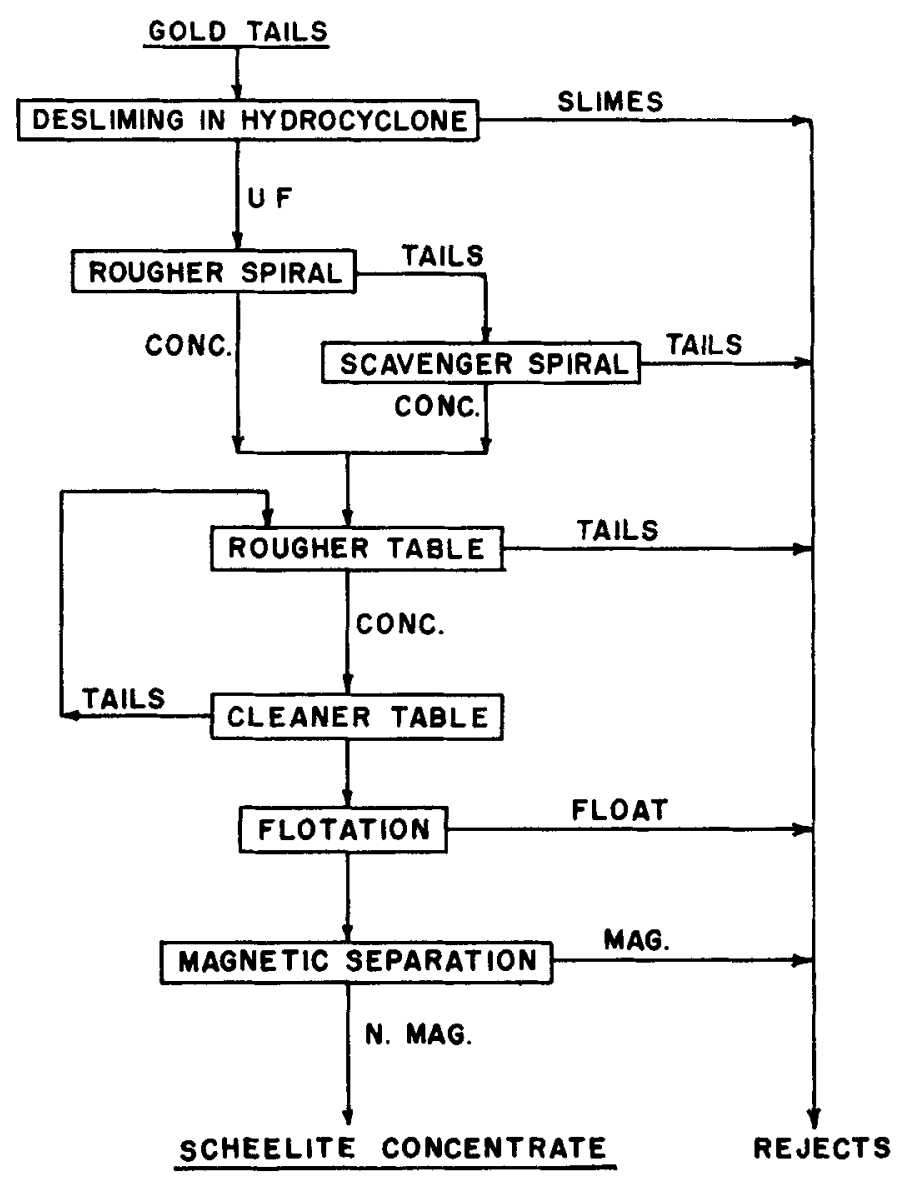

Figure 28. IBM flow-sheet (simplified, schematic) for the recovery of scheelite from KGF gold tailing dumps.

in the flow-sheet followed at the pilot plant. The salient features of the BARC investigations are described below.

10.2a Pre-concentration by spirals: Tests were carried out on spirals with test feed prepared in different ways--direct, after desliming, and after classification. While on direct spiralling a recovery of $63.5 \%$ was obtained in the spiral concentrate, the recovery improved to $75.8 \%$ on spiralling deslimed feed, and to $83 \%$ on feed classified into +100 and -100 \# fractions, at comparable enrichment ratios (Shukla et al 1983). The improvement of efficiency in spiralling is reflected in better recovery obtained in both coarse $(+100 \#)$ and very fine $(-400 \#)$ size fractions.

10.2b Pre-concentration by tabling: Direct tabling on a laboratory Deister table (slime deck) gave pre-concentrates assaying 4-5\% WO at $65-73 \%$ recovery. The wide range of size distribution and the presence of ultrafines affected the efficiency of tabling. When deslimed feed was tabled after classification into +100 \# and -100 \# fractions, considerable improvements in both grade and recovery were realized. Results obtained in different experiments are summarized in table 23. 
Table 23. Results of tabling of Walker's gold tailings after classification.

\begin{tabular}{|c|c|c|c|c|}
\hline Test No. & Product & Wt. $\%$ & $\mathrm{WO}_{3}$ assay $\%$ & $\mathrm{WO}_{3}$ dist. $\%$ \\
\hline \multirow[t]{3}{*}{1} & $+100 \#$ table conct. & $0 \cdot 19$ & $9 \cdot 40$ & $17 \cdot 1$ \\
\hline & $-100 \#$ table conct. & $0 \cdot 48$ & $11 \cdot 70$ & $54 \cdot 3$ \\
\hline & $\begin{array}{l}\text { Combined table conct. } \\
\text { Feed }\end{array}$ & 0.67 & $\begin{array}{r}11 \cdot 05 \\
0 \cdot 10\end{array}$ & $71 \cdot 4$ \\
\hline \multirow[t]{2}{*}{2} & $\begin{array}{l}+100 \# \text { table conct. } \\
-100 \# \text { table conct. }\end{array}$ & $\begin{array}{l}0.42 \\
0.32\end{array}$ & $\begin{array}{r}5 \cdot 20 \\
16 \cdot 60\end{array}$ & $\begin{array}{l}18 \cdot 8 \\
45 \cdot 3\end{array}$ \\
\hline & $\begin{array}{l}\text { Combined table conct. } \\
\text { Feed }\end{array}$ & 0.74 & $\begin{array}{r}10 \cdot 13 \\
0 \cdot 11\end{array}$ & $64 \cdot 1$ \\
\hline \multirow[t]{2}{*}{3} & $\begin{array}{l}+100 \# \text { table conct. } \\
-100 \# \text { table conct. } \\
\text { (Tabled after desliming) }\end{array}$ & $\begin{array}{l}0 \cdot 61 \\
1 \cdot 30\end{array}$ & $\begin{array}{l}5 \cdot 00 \\
6 \cdot 70\end{array}$ & $\begin{array}{l}20 \cdot 8 \\
59 \cdot 6\end{array}$ \\
\hline & $\begin{array}{l}\text { Combined table conct. } \\
\text { Feed }\end{array}$ & 1.91 & $\begin{array}{l}6 \cdot 16 \\
0 \cdot 146\end{array}$ & $80 \cdot 4$ \\
\hline \multirow[t]{2}{*}{4} & $\begin{array}{l}+100 \# \text { table conct. } \\
-100 \# \text { table conct. } \\
-100 \# \text { scav. table conct. }\end{array}$ & $\begin{array}{l}0 \cdot 22 \\
0 \cdot 20 \\
0 \cdot 21\end{array}$ & $\begin{array}{r}14 \cdot 80 \\
20 \cdot 60 \\
6 \cdot 60\end{array}$ & $\begin{array}{l}25 \cdot 9 \\
34 \cdot 0 \\
10 \cdot 9\end{array}$ \\
\hline & $\begin{array}{l}\text { Combined table conct. } \\
\text { Feed } \\
\text { (In this test classification wa }\end{array}$ & $\begin{array}{l}0.63 \\
\text { ne after }\end{array}$ & $\begin{array}{r}13-91 \\
0 \cdot 12 \\
\text { liming) }\end{array}$ & $70 \cdot 8$ \\
\hline
\end{tabular}

Table 24. Results of upgradation of table pre-concentrates from Walker's gold tails.

\begin{tabular}{|c|c|c|c|c|c|}
\hline $\begin{array}{l}\text { Expt. } \\
\text { no. }\end{array}$ & $\begin{array}{l}\text { Description of the } \\
\text { experiment }\end{array}$ & Product & Wt. $\%$ & $\begin{array}{c}\% \mathrm{WO}_{3} \\
\text { assay }\end{array}$ & $\begin{array}{c}\% \mathrm{WO}_{3} \\
\text { dist. }\end{array}$ \\
\hline \multirow[t]{4}{*}{1} & Flotation of arsenopyrite & Float & $42 \cdot 3$ & $0 \cdot 12$ & $0 \cdot 3$ \\
\hline & Magnetic separation of sink & Nonmagnetic & $30 \cdot 8$ & $75 \cdot 0$ & $96 \cdot 3$ \\
\hline & & Magnetic & 269 & $3 \cdot 4$ & 3.4 \\
\hline & Feed (clnr. table pre-conct.) & & $100 \cdot 0$ & $24 \cdot 0$ & $100 \cdot 0$ \\
\hline \multirow[t]{4}{*}{2} & Flotation of arsenopyrite & Float & $39 \cdot 6$ & $0 \cdot 14$ & $0 \cdot 2$ \\
\hline & Magnetic separation of sink & Nonmagnetic & $30 \cdot 2$ & $76 \cdot 0$ & 95.6 \\
\hline & & Magnetic & $30 \cdot 2$ & $3 \cdot 3$ & $4 \cdot 2$ \\
\hline & Feed (clnr. table pre-conct.) & & $100 \cdot 0$ & $24 \cdot 6$ & $100 \cdot 0$ \\
\hline \multirow[t]{4}{*}{3} & Flotation of arsenopyrite & Float & 49.6 & 1.9 & $5 \cdot 0$ \\
\hline & Magnetic separation of sink & Nonmagnetic & $22 \cdot 3$ & $75 \cdot 5$ & $88 \cdot 0$ \\
\hline & & Magnetic & $28 \cdot 1$ & $4 \cdot 9$ & $7 \cdot 0$ \\
\hline & Feed (clnr. table pre-conct.) & & $100 \cdot 0$ & $19 \cdot 2$ & $100 \cdot 0$ \\
\hline
\end{tabular}

10.2c Upgradation of the table concentrates: The main gangue minerals contained in the gravity concentrates were arsenopyrite $(20-25 \%)$ and amphiboles $(50-55 \%)$. Arsenopyrite was floated using amyl xanthate as collector and pine oil as frother.The flotation sink was subjected to high intensity magnetic separation. The nonmagnetic scheelite concentrate assayed $+70 \% \mathrm{WO}_{3}$ at over $90 \%$ stage recovery, starting from table concentrates assaying $20-25 \% \mathrm{WO}_{3}$ (cleaner table concentrates) (Shukla et al 1983). The results are given in table 24. 


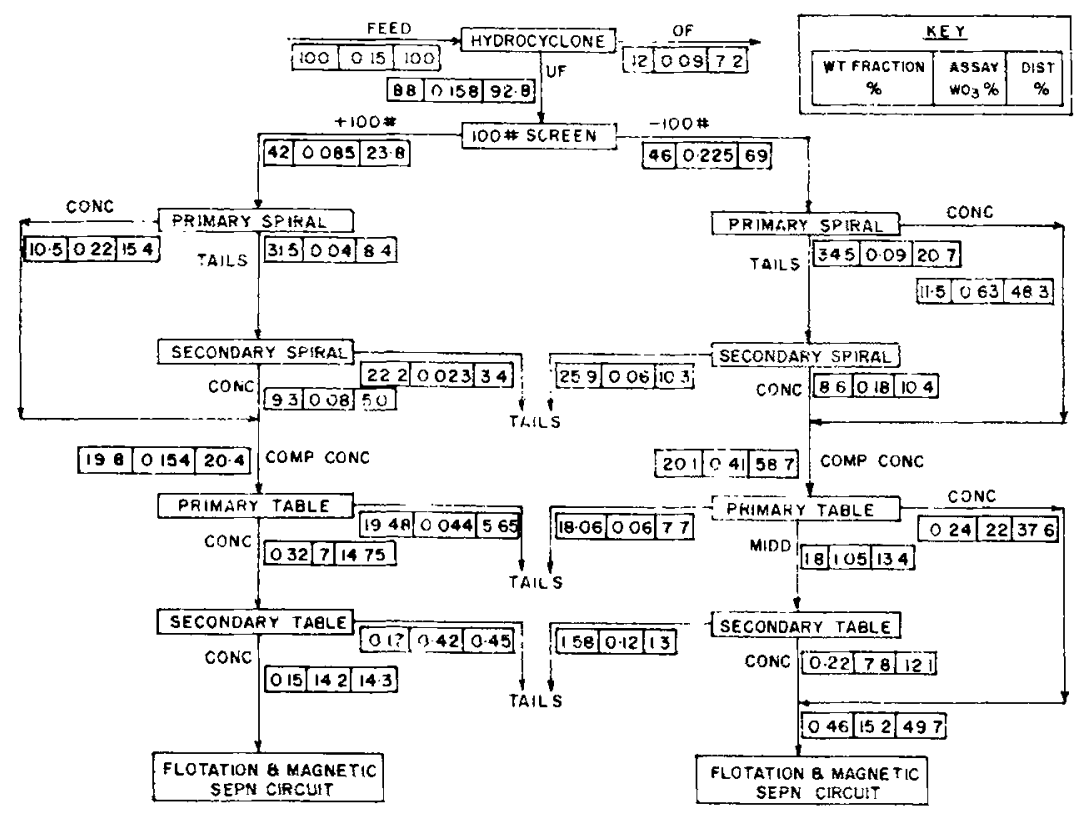

Figure 29. Flow-sheet of the semi pilot plant scale test 1 carried out at BARC on the recovery of scheelite from Walker's gold tailing dump (up to the pre-concentration stage), with metallurgical material balance.

10.2d Semi-pilot plant scale tests: Two alternative gravity beneficiation flow-sheets were formulated based on the batch test results, and a large scale test each was carried out following each flow-sheet. These tests were carried out up to the gravity preconcentration stage only. The two flow-sheets are schematically shown in figures 29 and 30 along with the material balance obtained at each stage. The flow-sheet involving spiralling gave a final gravity pre-concentrate of $14.7 \% \mathrm{WO}_{3}$ at $63.7 \%$ overall recovery, while that involving tabling of classified feed gave a final pre-concentrate assaying $13.8 \% \mathrm{WO}_{3}$ at $77.6 \%$ recovery.

10.2e Alternate flow-sheets: As an alternative to all gravity flow-sheet, processes involving direct flotation of scheelite were also attempted by Shukla and co-workers (Shukla et al 1974, 1985). Direct flotation of scheelite using oleic acid, sodium carbonate and pine oil in different concentrations gave rougher floats analyzing 0.5 to $0.8 \%$ $\mathrm{WO}_{3}$ at 66 to $72 \%$ recovery. Using a modified reagent combination on deslimed feed $74-76 \%$ recoveries could be obtained in floats assaying 3.8 to $5.2 \% \mathrm{WO}_{3}$ grade. Results are summarized in table 25 . As an alternative to direct flotation, which did not yield high grade concentrates, tabling followed by flotation of scheelite was also attempted. The results are included in table 25 . The table concentrates assayed 3 to $5 \%$ $\mathrm{WO}_{3}$ at recoveries of 63 to $75 \%$ ( 76 to $87 \%$ stage recovery from deslimed feed), and flotation using a combination of oleic acid, sodium carbonate and pine oil gave a float concentrate assaying 64.5 to $69.2 \% \mathrm{WO}_{3}$ at 82 to $86 \%$ stage recovery (52 to $56 \%$ overall recovery). Direct flotation certainly offers an attractive alternative to all gravity route. 


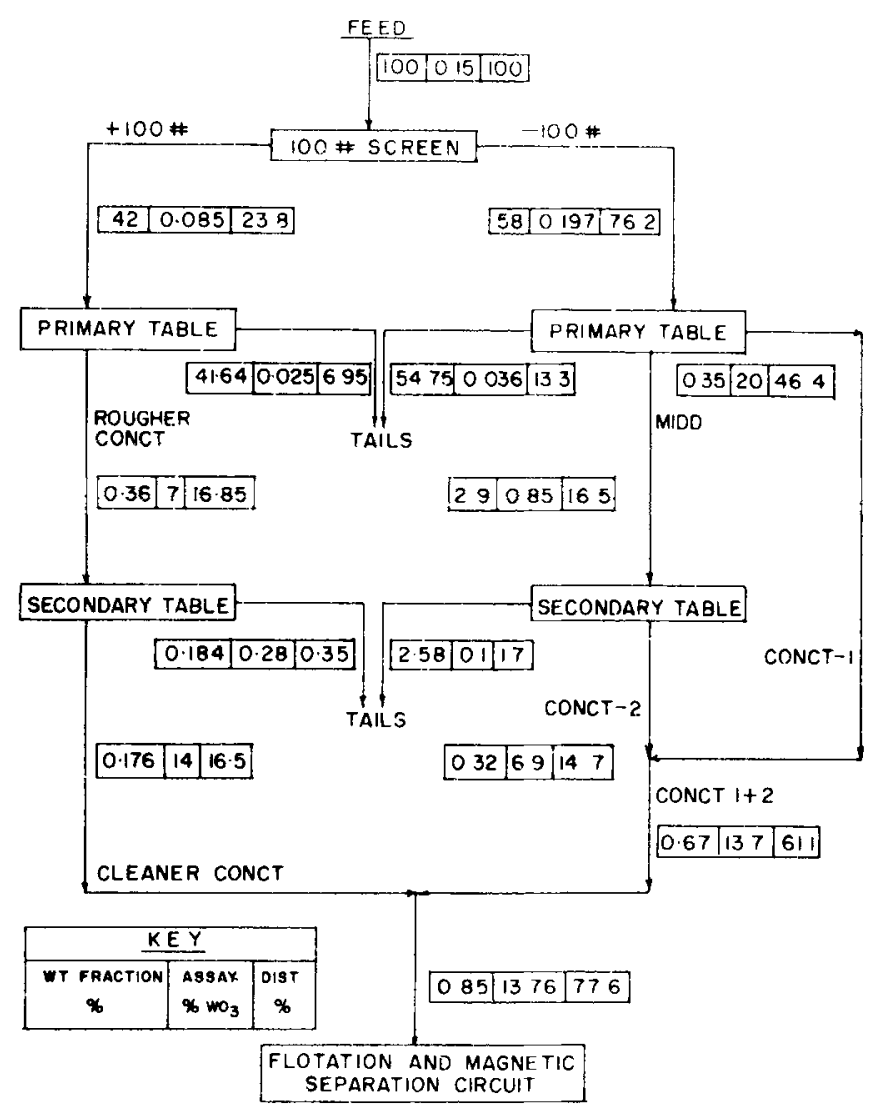

Figure 30. Flow-sheet of the semi pilot plant scale test 2 carried out at BARC on the recovery of scheelite from Walker's gold tailing dump (up to the pre-concentration stage), with metallurgical material balance.

\subsection{Discussion}

With near exhaustion of the high tenor Walker's gold tailing dump and the prospect of closing down of gold recovery operations at KGF in the near future, any feasibility of continuing recovery of scheelite from gold tails remains bleak. The existing flow-sheets, mainly based on gravity operations, cannot sustain economic recovery of scheelite from the leaner tenor $\left(<0 \cdot 1 \% \mathrm{WO}_{3}\right)$ dumps. A silver lining in this context is the study by Rao G V (1992), which has shown the feasibility of application of selective flocculation of scheelite fines as a means of pre-concentration.

\section{Scheelite bearing gold ore from Hutti, Karnataka}

The Hutti schist belt in the Raichur district of Karnataka, representing a part of the greenstone belt of the Dharwar craton, is well known for its gold mineralization. Association of scheelite mineralization in and around the auriferous lodes was noticed by Geological Survey of India during 1967--68. Since then a total reserve of more than a million tonnes of ore containing on an average $0.08 \% \mathrm{WO}_{3}$ have been proved or 
Table 25. Results of flotation of scheelite from Walker's gold tailings.

\begin{tabular}{|c|c|c|c|c|c|}
\hline $\begin{array}{l}\text { Expt. } \\
\text { no. }\end{array}$ & Reagent combination & $\begin{array}{l}\text { Wt. \% of } \\
\text { float }\end{array}$ & $\begin{array}{c}\mathrm{WO}_{3} \\
\text { assay } \%\end{array}$ & $\begin{array}{l}\mathrm{WO}_{3} \\
\text { dist. } \%\end{array}$ & $\begin{array}{l}\text { Feed } \\
\text { grade }\end{array}$ \\
\hline \multicolumn{6}{|c|}{ A. Direct flotation: } \\
\hline 1. & Oleic acid & $8 \cdot 2$ & 1.42 & $55 \cdot 0$ & 0.22 \\
\hline 2. & $\begin{array}{l}\text { Oleic acid } \\
\text { Sodium carbonate } \\
\text { Pine oil }\end{array}$ & $23 \cdot 4$ & $0: 67$ & $71 \cdot 5$ & $0 \cdot 18$ \\
\hline 3. & - do- & $14 \cdot 8$ & 0.80 & $70 \cdot 0$ & $0 \cdot 20$ \\
\hline 4. & $\begin{array}{l}\text { Reagent } 801 \\
\text { Sodium carbonate } \\
\text { Kerosene, pine oil } \\
\text { (after desliming) }\end{array}$ & $4 \cdot 2$ & 3.80 & $73 \cdot 5$ & 0.21 \\
\hline 5. & - do- & $2 \cdot 9$ & $5 \cdot 20$ & $75 \cdot 5$ & $0 \cdot 20$ \\
\hline $\begin{array}{l}\text { Expt. } \\
\text { no. }\end{array}$ & Product & Wt. $\%$ & $\begin{array}{c}\mathrm{WO}_{3} \\
\text { assay } \%\end{array}$ & $\begin{array}{l}\mathrm{WO}_{3} \\
\text { dist. } \%\end{array}$ & $\begin{array}{l}\text { Feed } \\
\text { grade }\end{array}$ \\
\hline \multicolumn{6}{|c|}{ B. Tabling followed by flotation (oleic acid + sod. carbonate + pine oil): } \\
\hline 1. & $\begin{array}{l}\text { Table concentrate } \\
\text { Float concentrate }\end{array}$ & $\begin{array}{l}3 \cdot 0 \\
0 \cdot 15\end{array}$ & $\begin{array}{r}4 \cdot 0 \\
64 \cdot 5\end{array}$ & $\begin{array}{l}67.7 \\
55.6\end{array}$ & $0 \cdot 18$ \\
\hline \multirow[t]{2}{*}{2.} & $\begin{array}{l}\text { Table concentrate } \\
\text { (after desliming)- }\end{array}$ & $3 \cdot 2$ & 3.5 & 63.6 & $0 \cdot 18$ \\
\hline & Float concentrate & $0 \cdot 13$ & $69 \cdot 2$ & $52 \cdot 5$ & \\
\hline
\end{tabular}

indicated (Anon 1985). Scheelite is found to occur as small lenses, stringers, veinlets, streaks, blebs and disseminations along the contacts of the auriferous grey quartz veins, in the form of grains and aggregates of 20 to 50 microns.

After extensive bench and pilot plant scale tests, IBM recommended a flow-sheet, schematically shown in figure 31, giving a scheelite concentrate of 62 to $65 \% \mathrm{WO}_{3}$ at a recovery of $32 \%$ (Anon 1985). Work carried out in association of Golder Moffit Associates of U. K. showed that by use of Bartles fine gravity machines (BMS and CBC), additional scheelite could be recovered from the table tails. Tests carried out at Cornwall, in association with Bartles Company enabled formulation of a process flowsheet involving processing the coarse stream in a table circuit (32\% recovery) and treating the fines on Bartles machines. The fines recovery flow-sheet, given in figure 32, includes pre-concentration on Bartles Mozley separator, concentration on Bartles cross belt concentrator, and upgradation to a product of $74 \% \mathrm{WO}_{3}$ by alkaline pressure leaching and synthetic scheelite precipitation. This stage gives an additional $20 \%$ recovery, making a total of $52 \%$ recovery.

Work carried out by HGML in association with Lurgie Gmbh, Germany, showed that it is possible to produce $\mathrm{WO}_{3}$ concentrates of $65 \%$ grade at a recovery of $70 \%$ by a process consisting of flotation and leaching. The beneficiation process developed (Raju et al 1987) involves flotation of sulphides using xanthate, and scheelite by using a special reagent developed specially for Hutti ore, and cleaning the rougher scheelite float in four cleaner flotation stages. The cleaner concentrate is upgraded by acid leaching. The possibility of applying the same process to recover scheelite from the Hutti gold tailings was also investigated, which however did not yield encouraging results. 


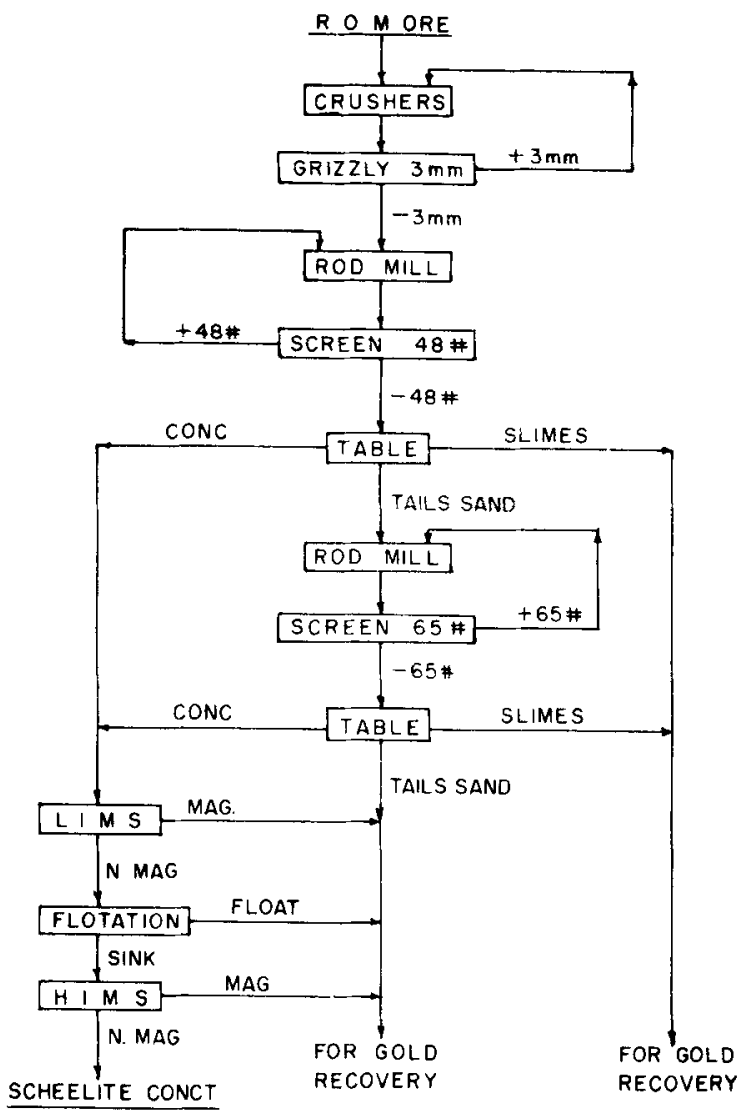

Figure 31. Gravity beneficiation flow-sheet (schematic) for the recovery of scheelite from Hutti gold ore, suggested by IBM.

It is now understood that the question of putting up a scheelite beneficiation plant at Hutti has been kept in abeyance due to the depressed condition of world tungsten concentrate market.

\section{Scheelite ore from Madurai district, Tamilnadu}

A sample of the ore made available by Geological Survey of India to BARC for beneficiation tests assayed $0 \cdot 2 \% \mathrm{WO}_{3}$. The mineralogical composition of the sample is given in table 26. Liberation analysis indicated that most of scheelite was liberated at a relatively coarse size of -35 \#. Rao et al (1988) studied the beneficiation characteristics of this ore sample.

Results of bench scale beneficiation tests are summarized in table 27. Direct tabling of the ground ore in two stages (rougher and cleaner) gave a concentrate assaying $5.6 \%$ $\mathrm{WO}_{3}$ at $86 \%$ recovery, which on magnetic separation gave a scheelite concentrate of $27 \% \mathrm{WO}_{3}$. This showed the prima facie amenability of the ore to gravity beneficiation.

In the second test the ore crushed to all passing through 28 \# was jigged in a Denver mineral jig and the jig pre-concentrate (grade $0.5 \% \mathrm{WO}_{3}, 57 \%$ recovery) tabled. The 


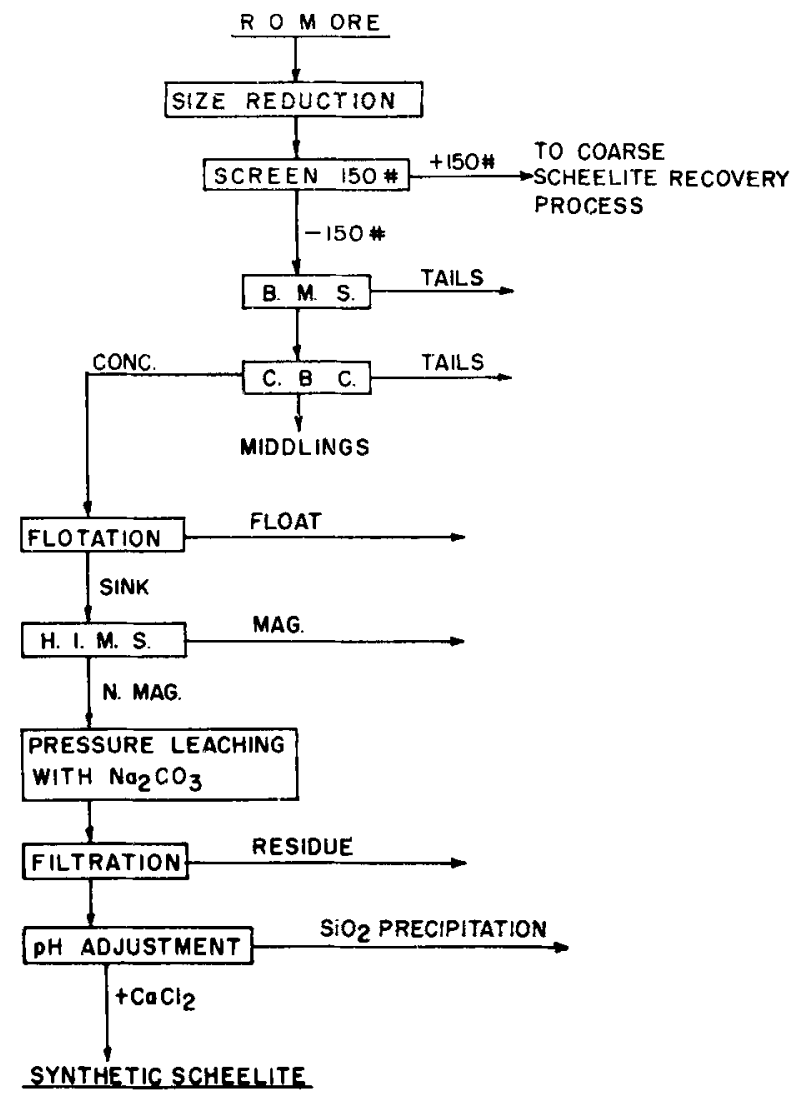

Figure 32. Flow-sheet (schematic) of the Fines gravity circuit for the recovery of scheelite from Hutti gold ore slimes, based on HGME-GMA (UK) tests.

Table 26. Mineralogical composition of Madurai scheelite ore.

\begin{tabular}{lc}
\hline Mineral & Weight \% \\
\hline Quartz and Felspar & $58 \cdot 8$ \\
Pyroxene & $23 \cdot 8$ \\
Garnet & $13 \cdot 5$ \\
Sphene & $0 \cdot 9$ \\
Apatite & $0 \cdot 5$ \\
Fluorite & $2 \cdot 0$ \\
Scheelite & $0 \cdot 3$ \\
Opaques (magnetite, cassiterite, & $0 \cdot 2$ \\
$\quad$ ilmenite, pyrite etc.) & \\
Total & $100 \cdot 0$ \\
\hline
\end{tabular}

table concentrate on magnetic separation yielded a high grade scheelite concentrate assaying $74.5 \% \mathrm{WO}_{3}$ with nearly $98 \%$ stage recovery. The jig tails on scavenging by table, followed by magnetic separation gave another low grade concentrate of $8 \% \mathrm{WO}_{3}$. 
Table 27. Experimental results of beneficiation of scheelite ore from Madurai. Tamilnadu.

\begin{tabular}{|c|c|c|c|}
\hline \multirow[b]{2}{*}{ Process } & \multicolumn{3}{|c|}{ Scheelite concentrate } \\
\hline & Wt. $\%$ & $\mathrm{WO}_{3} \%$ & $\mathrm{WO}_{3}$ Dist. $\%$ \\
\hline \multicolumn{4}{|l|}{$\begin{array}{l}\text { Direct tabling, mag. separation } \\
\text { of table concentrate }\end{array}$} \\
\hline \multicolumn{4}{|l|}{ Feed assay $0.203 \% \mathrm{WO}_{3}$} \\
\hline N. mag. of T.C. & 0.59 & $26 \cdot 6$ & $77 \cdot 7$ \\
\hline \multicolumn{4}{|l|}{$\begin{array}{l}\text { Jigging. tabling of jig hutch } \\
\text { and tails, mag. sepn. of jig hutch } \\
\text { and table conc. }\end{array}$} \\
\hline \multicolumn{4}{|l|}{ Feed $0.223 \% \mathrm{WO}_{3}$} \\
\hline N. mag. of jig hutch & $0 \cdot 166$ & $74 \cdot 5$ & $55 \cdot 7$ \\
\hline N. mag. of table conc. & $0 \cdot 551$ & 8.0 & $19 \cdot 2$ \\
\hline \multicolumn{4}{|l|}{$\begin{array}{l}\text { Classification at } 100 \# \text {, tabling. } \\
\text { Magnetic separation of table conc. } \\
\text { (For flow-sheet see figure } 33 \text { ) }\end{array}$} \\
\hline \multicolumn{4}{|l|}{ Feed assay $0.165 \% \mathrm{WO}_{3}$} \\
\hline N. mag. of table conc. $1(+100 \#)$ & $0 \cdot 105$ & $67 \cdot 3$ & $43 \cdot 2$ \\
\hline N. mag. of table conc. $2(+100 \#)$ & 0.038 & $37 \cdot 8$ & $8 \cdot 4$ \\
\hline N. mag. of table conc. $3(-100 \#)$ & $0 \cdot 184$ & $27 \cdot 0$ & $30 \cdot 2$ \\
\hline
\end{tabular}

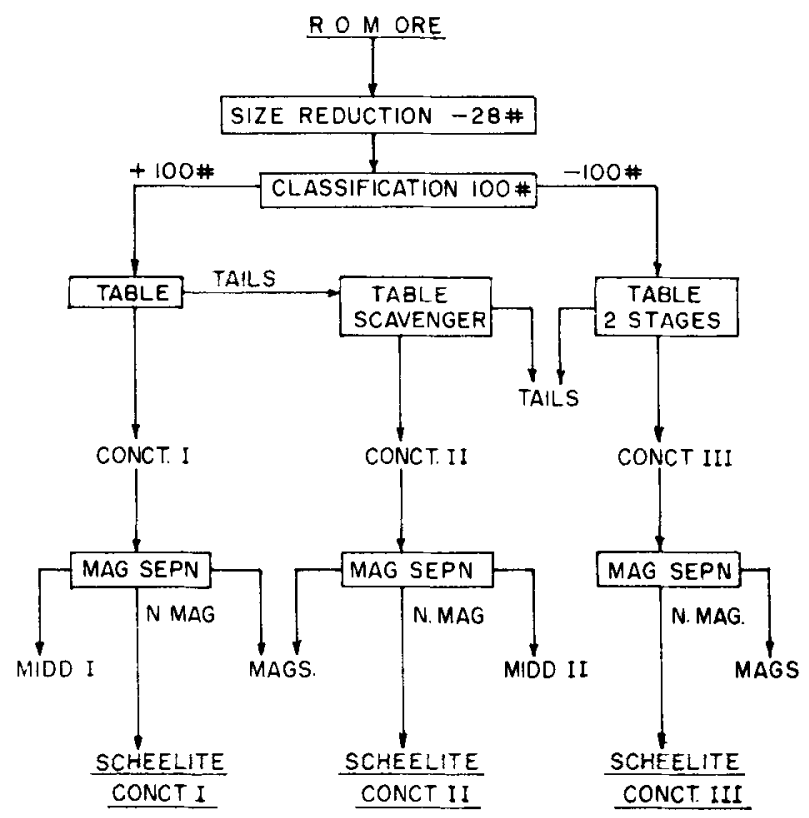

Figure 33. Flowchart of the beneficiation test carried out on the Madurai skarn-type scheelite ore (for results see table 27).

In the third test, classification followed by tabling route was followed. The scheme of the test is shown in figure 33. The results are included in table 27. At the preconcentration stage nearly $86 \%$ recovery could be obtained, and on cleaning followed 


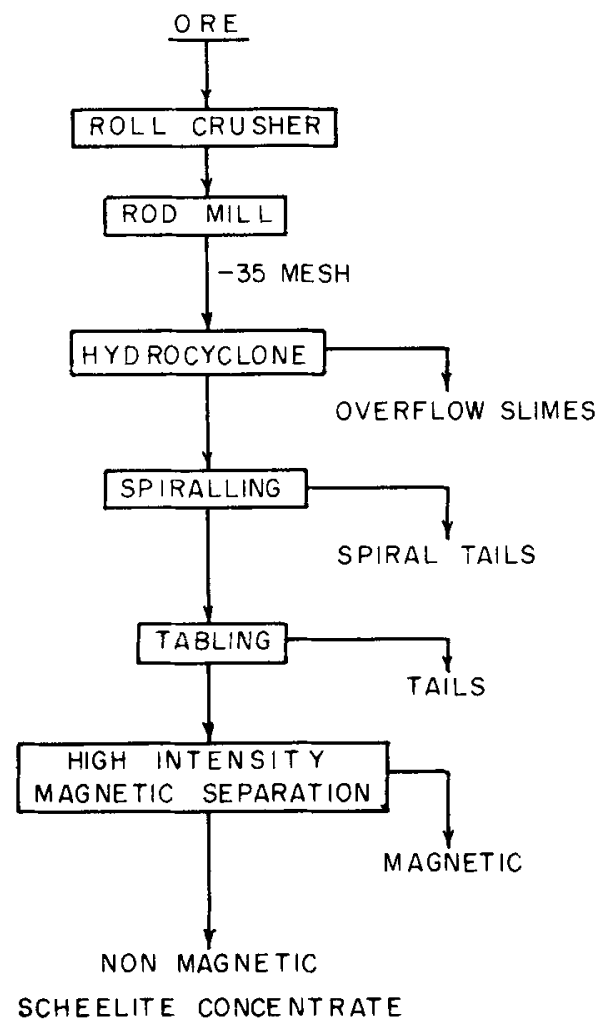

Figure 34. Flow-sheet I (schematic) suggested for the beneficiation of Madurai scheelite ore.

by magnetic separation resulted in a combined scheelite concentrate of $41 \% \mathrm{WO}_{3}$ at a high overall recovery of nearly $82 \%$. By optimizing the process parameters at the tabling stage (i.e. by collecting a higher grade concentrate, or by a cleaner stage) it should be possible to obtain a final concentrate of marketable grade at a minimum of $75 \%$ overall recovery.

Based on these bench scale test results two flow-sheets were suggested (Rao et al 1988) for large scale pilot plant scale testing, which are schematically shown in figures 34 and 35.

\section{General discussion and conclusions}

In order to achieve self reliance in strategic metals Rama Rao (1990) has called for an integrated 'ore to product' approach as a framework. Tungsten is one of the metals where the ore end of the situation in the country is not comfortable, while excellent know-how exists for extraction and production techniques. To make the ore to product concept successful in the case of tungsten, the urgent need is the development of techno-economically feasible process flow-sheets for the beneficiation of the reasonably good reserve potential of tungsten deposits in the country.

The foregoing description of the investigations carried out by different researchers and agencies, particularly the national laboratories like BARC, IBM, NML, RRL 


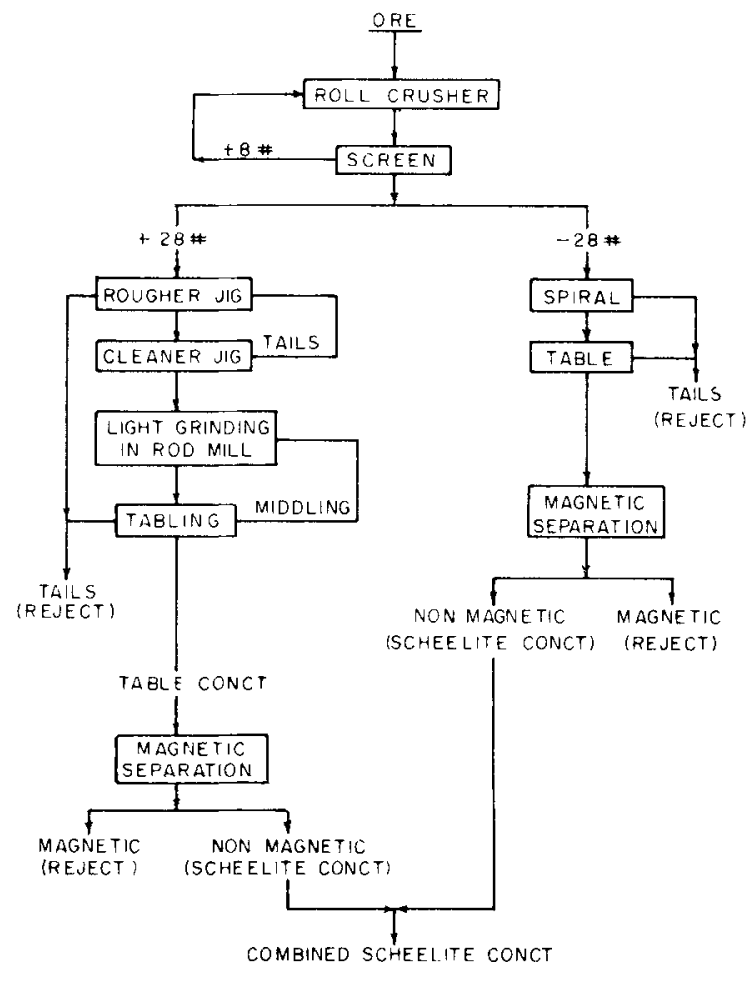

Figure 35. Flow-sheet II (schematic) suggested for the beneficiation of Madurai scheelite ore.

(Bhubaneswar), etc. have amply proved the technical feasibility of beneficiation of the various potential low grade tungsten deposits of the country. But the economic viability of exploitation does not depend only on technical feasibility. Factors like tenor of the ore, minimum economic level of throughput. complexity of the beneficiation process flow-sheet. overall recovery achievable, grade and purity of the concentrates. etc play major roles in the economic viability of exploitation.

Experience in the development of flow-sheets for the beneficiation of low grade ores of strategic metals like tungsten and tin has shown the necessity of adopting the following basic strategies in order to make the process techno-economically feasible and competitive (Rao N K 1992). These are:

1. Size reduction in stages to meet the philosophy of "the earlier recovered the more recovered" and to avoid generation of "difficult to treat" slimes.

2. An effective pre-concentration step in a high throughput and efficient operation aiming at high recovery, rejecting bulk of the barren material in the initial stage at as coarse a size as possible, and to confine the mineral values to a small volume, which can be subjected to drastic processing steps cost effectively.

3. Improving the economics of operation by the concept of maximum utilization by the recovery of all potential byproducts.

4. Keeping in view a long term perspective for technology development and upgradation.

5. Aiming at an economic level of concentration with maximum recovery (rather than high grade at the cost of recovery), by a judicious combination of physical and chemical methods of beneficiation. 
Table 28. Potential of Degana tungsten ores.

\begin{tabular}{|c|c|c|c|c|c|c|c|}
\hline \multirow[b]{2}{*}{ Ore type } & \multirow[b]{2}{*}{$\begin{array}{c}\text { Average } \\
\text { tenor, } \\
\mathrm{WO}_{3}, \mathrm{~kg} / \mathrm{T}\end{array}$} & \multicolumn{2}{|c|}{$\begin{array}{c}\text { Single high grade } \\
\text { product }\end{array}$} & \multicolumn{3}{|c|}{ Two grade products } & \multirow[b]{2}{*}{$\begin{array}{c}\text { Additional } \\
\text { recovery } \\
\text { by two } \\
\text { product } \\
\text { approach } \\
\mathrm{WO}_{3}, \mathrm{~kg} / \mathrm{T}\end{array}$} \\
\hline & & $\% \operatorname{Rec}$ & $\begin{array}{l}\text { Recovered } \\
\mathrm{WO}_{3}, \mathrm{~kg} / \mathrm{T}\end{array}$ & $\begin{array}{l}\text { High grade } \\
\text { product } \\
\% \text { Rec. }\end{array}$ & $\begin{array}{l}\text { Low grade } \\
\text { product } \\
\% \text { Rec. } \\
\text { (with } \mathrm{WO}_{3} \\
\text { grade in } \\
\text { brackets) }\end{array}$ & $\begin{array}{c}\text { Total } \\
\text { recovered } \\
\mathrm{WO}_{3} \\
\mathrm{~kg} / \mathrm{T}\end{array}$ & \\
\hline Quartz vein & 2 & 60 & 1.2 & 50 & $25(20 \%)$ & 1.5 & $0 \cdot 3$ \\
\hline Eluvial & $0 \cdot 3$ & 50 & $0 \cdot 15$ & 40 & $30(20 \%)$ & 0.21 & 0.06 \\
\hline Phyllite & $0 \cdot 2$ & - & - & - & $50(10 \%)$ & $0 \cdot 10$ & $0 \cdot 10$ \\
\hline \multirow[t]{2}{*}{ Granite } & 0.4 & - & - & -- & $50(20 \%)$ & 0.20 & 0.20 \\
\hline & $1 \cdot 0$ & 30 & $0 \cdot 3$ & 25 & $40(10 \%)$ & 0.65 & 0.35 \\
\hline
\end{tabular}

The concept contained in item 5 above needs elaboration. There is no doubt that most of our tungsten deposits are of inferior tenor, or of low tonnage, or both, and hence a strategy different from the countries endowed with richer and larger deposits is called for. While developing beneficiation flow-sheets it is often sought to achieve what are called marketable grade concentrates. But India, which imports bulk of its requirements, is not in the run for marketing tungsten concentrates, on the other hand, what we need are 'utilizable grade concentrates' or 'concentrates of economic enrichment'. To make exploitation of low tenor ores feasible, the emphasis has to be on the production of such concentrates of economic enrichment, with emphasis on recovery, rather than marketable grade concentrates with emphasis on grade. The concept of 'forward integration' put forward by Borchers (1979) is relevant in this connection. In this strategy leaner grade concentrates of economic enrichment, which can vary from 5 to $40 \% \mathrm{WO}_{3}$ are directly utilized, or are further processed by chemical beneficiation or extraction methods to produce directly usable products like APT, tungsten oxide powder or synthetic scheelite.

This concept in most cases calls for production of two types of concentrates, a high grade product of what is called marketable grade concentrate that is feasible by a simple process of upgradation, and a low or medium grade product containing all the rest recoverable values. The advantage of this approach of maximizing recovery is illustrated by taking the example of Degana ore deposits. Table 28 illustrates the feasible recoveries under the two approaches.

Economically exploitable reserves of the quartz-vein type tungsten ore in Degana, which is amenable for beneficiation to produce marketable grade concentrates at high recoveries, are nearly exhausted. Continuing underground mining has become economically unsustainable in the present depressed world tungsten scenario. Continuation of Degana in the tungsten scene will depend on large scale exploitation of richer portions of the fertile granite as a whole (or the so called trench lode granite) minable by open cast methods. It is heartening to note that Hindustan Zinc Ltd., who have now taken over the Degana tungsten property, are in the process of preparation of feasibility report on this line of activity (Wadhavan 1992).

Though marketable grade concentrates of scheelite can be produced at reasonably good recoveries from the Khobna deposit, maximizing recovery of the strategic metal 


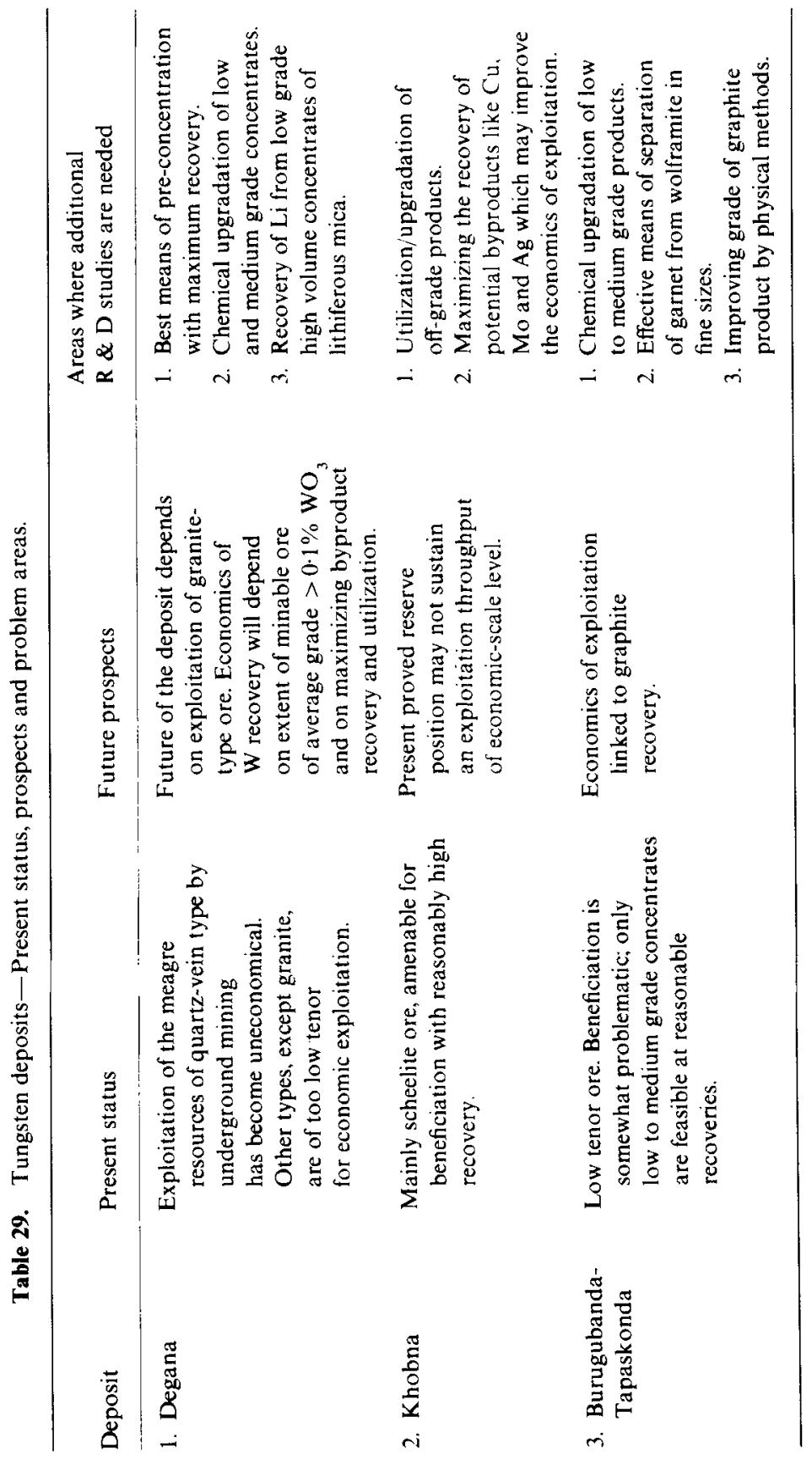


tungsten calls for the production of a low to medium grade product too, as already explained. As far as the Burugubanda-Tapaskonda deposit is concerned, there is no alternative to production of a low to medium grade wolframite concentrate, if reasonably good recoveries are desired. In order to optimally utilize all these low to medium grade products, it is necessary to develop indigenous technology for their chemical upgradation into directly usable products. A good beginning has been made in this direction in some of the recent publications on the subject (Paramaguru et al 1987; NML Rept. 1990; Srinivasan et al 1991; Subramanian et al 1992). Results obtained in the NML study (Premchand 1993), following the pressure leaching with soda followed by solvent extraction, are highly encouraging. A technology which is applicable for both wolframite and scheelite concentrates and their mixtures, however, will be most appropriate and desirable in the context of optimizing the utilization and conservation of scarce tungsten resources of the country.

In the present knowledge of indigenous resources position of tungsten, the most promising deposits are only three, namely, Degana in Rajasthan, Khobna in Maharashtra and Burugubanda-Tapaskonda in Andhra Pradesh. Table 29 sums up the present status, future prospects and problem areas where more $\mathrm{R} \& \mathrm{D}$ inputs are needed to make the exploitation of these deposits economical and more attractive.

\section{Acknowledgements}

The author wishes to thank Dr C K Gupta, Director, Materials Group, BARC for his sustained interest and encouragement. He wishes to place on record his deep sense of appreciation for the help rendered by all his colleagues in the Ore Dressing Section, BARC, particularly Mr S K Shukla, Mr T Sreenivas, Mr N P H Padmanabhan, Mr D Narasimhan and Mr T S Sunilkumar.

\section{References}

Anon 1979 Mining Mag. 28

Anon 1985 Tungsten mineral commodity survey, Report of sub-committee on strategic minerals (Group XII) (Nagpur: Geological Survey of India) pp 70-78

Anon 1988 Tungsten mineral commodity survey, Report of sub-committee on strategic minerals (Group XII) (Nagpur: Geological Survey of India) pp. 1-15

Anon 1988 Minutes of the second meeting of the Project Monitoring Committee on Tungsten Development sponsored by DRDO/DMRL - Report of the specialist committee.

Anon 1988 Beneficiation of tungsten ores, Report of the sub-committee on strategic minerals (Group XII), (Nagpur: Geological Survey of India) pp. 54-57

Anon 1991 Metal New' 1325

Auge P. Bahr A and Koser H 1975 Proc. 11th International mineral processing congress (Cagliari: Univ. of Cagliari) pp 691-712

Babok V K and Viduetskii M B 1967 USSR Patent No. 202, 020.

Baldin S A, Viktorov M N and Tereshkov V N 1984 Tsvetn. Met. 198488

Banerjee S K and Narayanan P I A 1952 NML Internal Report No. 11/52

Bansal R K, Lahiri A K and Bahree R C 1987 Tungsten resources development, 1987, Proc. national workshop on tungsten resources development (Bhubaneswar) pp. $77-86$

Bhattacharjee J. Chattopadhy:a B. Mukhopadhyay and Sweta Chattopadhyay 1987 Tungsten resources development. 1987. Proc. nutional workshop on tungsten resuurces development (Bhubaneswar) pp. 55-60

Bhoskar K G, Mohan M. Jain S S, Mohanty A K and Saha A K 1987 Tunysten resources development, 1987. Prox. natomal workshop on tungsten resources decelopment. RRL (Bhubaneswar), DMRL (Hyderabad) pp. $21 \quad 32$ 
Borchers P 1979 Tungsten, Proc. 1st international tungsten symp., (Stockholm, London: Mining Journal Books) pp. $64-77$

BRGM-MECL Tin Tungsten Collaboratıve Programme Burugubanda Tapaskonda Tungsten Project, 1990 Pre-feasibility Report on economic recoverability of tungsten from the Burugubanda deposit, D-2 Stage (Unpublished)

BRGM-MECL Tin Tungsten Collaborative Programme-Khobna Tungsten Project, 1991 Pre-feasibility Report on Khobna Tungsten Deposit, D-2 Stage. Vol. 1, Chapter: Beneficiation, pp. 1-41 (Unpublished)

Chatterjee A K. Negi M S, Rao K S and Singh L 1987 in Tungsten resources development, 1987, Proc. national workshop on tungsten resources development, RRL (Bhubaneswar) and DMRL (Hyderabad) pp. $47-54$

Datta P S 1987 Tungsten resources development, 1987. Proc. nutonal workshop on tungsten resources development, RRL (Bhubaneswar) and DMRL (Hyderabad) pp. 61- 70

Dawei W, Keron W and Jicun Q 1986 IJMP $7361-71$

Dwivedy K K 1988 Beneficiation of tungsten ores; Repurt of the sub-committee on strategic minerals (Group $X I I),(N a g p u r:$ Geological Survey of India) pp. $58-63$

Ermolenko V I, Yur'ev V 1, Nesterov V G, Berdichevskii B I and K rasıvina LE 1985 Tsvetn. Met. 198585-88

Gak T L, Bayshulakov A A and Gucalyuk T G 1983 lzt, Vysh. Ucheb. Zated. Cret. Metal 198316

Ghosh C, Pai D R. Narasimhan J B and Majumdar K K 1968 BARC Internal Report BARC/Met/12 1968

Han K N and Say W C 1985 Chem. Abstr. 103 40343r

Indian Bureau of Mines 1977 Pilot plant studies at site on recovery of scheelite from Walker tailing dump. Kolar Gold Fields IBM, R. I. No. 35 ?

Jarrett R G and Warren L. J 1977 Proc. Australasian Inst. Min. Metall. $26257-65$

Karahan S, Demirci A and Atamedir R 1980 World Mining 334651

Kelsall G H and Pitt J L 1987 Chem. Enyg. Sci. 42679

Koh P, Andrews $J$ and Uhlhen P 1986 IJMP 1745

Kunwar R K. Chakrabarti D M and Mathur G P 1972 NML Internal Report No. 668/72

Lahiri A K and Patni S K 1988 Beneficiation of tungsten ores, Report of the sub-committee on strategic minerals (Group XII), (Nagpur: Geological Survey of India) pp. 121-125

Minnonov I I, Ermolenko V I, Yur'ev V I, Zvrev V V and Litvintsev E G 1987 Tsvetn. Met. 1987 99-101

Mitchell W Jr. Sollengerger C L and Kirkland T B 1951 Trans. AIME 190 pp. $60 \cdot 64$

Narasimhan D 1989 Petrographic Report on Khobna-ll ore from Khobna, Maharashtra: Annexure to Laboratory studies on the beneficiation of tungsten ore from Khobna, Maharashtra, by Shukla et al Report submitted by ODS, BARC to MECL (Unpublished)

Narasimhan J B, Degalesan S N and Majumdar K K 1972 BARC Internal Report, BARC/1-200/1972

Narasimhan K S 1988 Beneficiation of tungsten ores; Report of the sub-committee on strategic minerals (Group $X I I$ ), (Nagpur: Geological Survey of India) pp. 110120

National Metallurgical Laboratory. Mineral Beneficiation Group, 1990 Chemical beneficiation studies: Interim Reports 4 and 5 on NML Thrust Area Project on Beneficiation and purification of tungsten ores of India, sponsored by DRDO/DMRL, April 1990 and Oct. 1990

National Metallurgical Laboratory 1992 Report on physical beneficiation of tungsten ore and preconcentrate samples from Degana Rajasthan (Unpublished Report) pp. 1-94

Ottley J D 1979 Minerals Sci. Eny. 11 99. 121

Padmanabhan N P H, Rambabu Ch, Das K K, Rao G V U and Pradip 1985 Progress in metallurgical research: fundamental and applied aspects (eds) S P Mehrotra and T R Ramachandran (Kanpur: IIT) pp. 39- 44

Padmanabhan N P H, Rambabu Ch. Pradip Das K K. Venkitakrishnan R R, Narasimhan D and Rao G V U 1984 Beneficiation of wolframite ore from Degana, Rujasthan, Report submitted by ODS, BARC to RSTDC, Rajasthan (LInpublished)

Padmanabhan N P H, Rao M M. Sivaramakrishnan K, Sunil Kumar T S and Rao N K 1991 Studies on benefictation of wolframite-yraphite ore from Burugubanda, Andhra Pradesh. Part I. Beneficiation studies: Report submitted by ODS, BARC to MECL (Unpublished).

Padmanabhan N P H, Sreenivas T and Rao N K 1990 High Temp. Mater. \& Process. 9217

Paramaguru R K. Jena K N and Sahoo P K 1987 Tungsten resource's detelopment. 1987. Proc. national workshop on tunysten resources development, RRL (Bhubaneswar) and DMRL (Hyderabad) pp. 117- 122

Patni S K. Lahiry A K and Bahree R C 1987 Tungsten resources development. 1987. Proc. national workshop on tungsten resources decelopment RRL. (Bhubaneswar) and DMRL (Hyderabad) pp. $41 \div 46$

Premchand 1993 Processing of low yrade tungsten ore concentrates by hydrometallurgical route - technology and economic issues with particular reference to India. Preprint Copy, pp. $1-35$ 
Raju K K, Krishnan R, Gururaj Naik J S and Mahanti S C 1987 Tungsten resources development, 1987, Proc. national workshop on tungsten resources development, RRL (Bhubaneswar) and DMRL (Hyderabad) pp. 109-116

Ramanamurthy V V, Dhargave R G, Doifode K T, Barthwal Y M, Kapale K Y, Sutaone A T, Ruikar M R and Rao G M 1990 Bulk testing of tungsten-graphite sample from Burugubanda Area, Andhra Pradesh Report of Investigation No. IBM/R.I. Submitted by IBM to MECL (Unpublished)

Rama Rao P 1990 Metal News 122

Rao G M 1993 Miner.\& Metals Rev. 13

Rao G M and Satyanarayana K 1987 Tungsten resources development, Proc. national workshop on tungsten resources development, RRL (Bhubaneswar) and DMRL (Hyderabad) pp. 87-90

Rao G M and Subrahmanyan N N 1988 Beneficiation of tungsten ores: Report of the sub-committee on strategic minerals (Group XII) (Nagpur: Geological Survey of India) pp. 34-53

Rao G V 1992 Trans. Indian Inst. Metals 45 275-281

Rao M M, Padmanabhan N P H and Rao N K 1992 Proc. national seminar on gravity concentration, $R R L$, Bhubaneswar, Preprint Vol. pp. 217-226

Rao M M, Shukla S K, Narasimhan D, Iyer N V and Rao N K 1988 Recovery of scheelite from tungsten ore from Karungalakudi, Madurai District, Tamilnadu: Report submitted by ODS, BARC to GSI, Economic Geology Division, Tamilnadu (unpublished)

Rao N K 1991 Proc. Indo-US workshop on advances in chemical metallurgy, Bombay (eds) C K Gupta, M K Totlani and N Birks (New Delhi: DST and Washington: NSF) pp. 115-122

Rao N K 1992 Exploration of low grade ores of strategic metals in India-Role of the ore dressing strategy: Platinum Jubilee Lecture delivered at the 79th Session of Indian Science Congress, Baroda

Save M and Conil P 1990 BRGM-Mecl Tin-Tungsten collaborative programme, Burugubanda Tungsten Project Phase 2, Semi pilot plant beneficiation of Burugubanda (India) graphite tungsten ore Report submitted by BRGM to MECL (Unpublished)

Sehgal M N and Suryanarayana M 1987 Tungsten resources development, 1987, Proc. national workshop on tungsten resources development, RRL (Bhubaneswar) and DMRL (Hyderabad) pp. 1-12

Shao Varui and Shi Daxin 1986 Chem. Abstr. $105156514 \mathrm{t}$

Shukla S K, Kumar K V, Majumdar K K and Degaleesan S N 1974 Studies on the beneficiation of scheelite from Kolar gold tailings Report submitted by ODS, BARC to BGML (Unpublished)

Shukla S K, Natarajan R, Das K K, Venkitakrishnan R R, Subrahmanyam N P and Rao G V U 1983 Laboratory investigations on improving the recovery of scheelite from gold tails Report submitted by ODS, BARC to BGML (Unpublished)

Shukla S K, Natarajan R, Das K K, Venkitakrishnan R R, Subrahmanyam N P and Rao N K 1985 Proc. national seminar on mineral processing and IX Annual convention of IIME., Jamshedpur, Preprint Vol. pp. 259-271

Shukla S K, Padmanabhan N P H, Rao M M, Subrahmanyam N P, Venkitakrishnan R R and Rao N K 1985 Beneficiation of phyllite-type low grade wolframite ore from Degana, Rajasthan Report submitted by ODS, BARC to RSTDC, Rajasthan (Unpublished)

Shukla S K, Rao M M, Subrahmanyam N P, Iyer N V and Rao N K 1988 BARC External Report BARC/1408

Shukla S K, Rao M M, Venkitakrishnan R R and Rao N K 1989 Laboratory studies on the beneficiation of tungsten ore from Khobna, Maharashtra Report submitted by ODS, BARC to MECL (Unpublished)

Shukla S K, Rao M M, Venkitakrishnan R R, Murthy P S, Narasimhan D and Rao N K 1991 Beneficiation studies on Khobna tungsten ore samples - Semi pilot plant scale tests; Report submitted by ODS, BARC to MECL (Unpublished)

Shukla S K and Rao N K Beneficiation of tungsten ores (Geological Survey of India (Under publication))

Srinivasan G N, Murthy B V R, Sahu B N, Jouhari A K, Dey D N and Jena P K 1991 Trans. Indian Inst. Metals 44167

Stafford P T 1985 Minerals, facts and problems (Washington: U.S. Dept. Interior) p. 881

Subramanian C, Suri A K, and Gupta C K 1992 Trans. Indian Inst. Metals 45 207-213

Sun Shanlun, Chen Quiren and Yang Yue 1984 Proc. miner. proc. extr. metal conference (eds) M J Jones and P Gill (Kunming, China: Inst. Min. Metal and Chinese Society of Metals) p. 521

Sunil Kumar T S and Rao N K 1991 Studies on beneficiation of wolframite-graphite ore from Burugubanda, Andhra Pradesh, Part II. Petrographic studies; Report submitted by ODS, BARC to MECL (Unpublished)

Svoboda J 1988 Magnetic methods for the treatment of minerals: developments in minerals processing (ed.) D W Fuerstenau (Amsterdam: Elsevier) Vol. 8, p. 538 
Tata Research Development and Design Centre, Pune, 1991 Final progress report on development of selective flocculation technology for recovery of tungsten values from slimes (Vol. 1), Submitted to Dept. Mines, Government of India, New Delhi

Texeira O C G, Oliveira J F and Villas Boas R C 1988 Developments in mineral processing: Froth flotation (eds) S H Castro and J Alvarez (Amsterdam: Elsevier) pp. 175-184

Vasquez L A, Ramachandran S and Grauerholz N L 1976 Flotation- A. M. Gaudin Memorial Volume (ed.) M C Fuerstenau, pp. 580-596

Wadhavan A C 1992 Trans. Indian Inst. Metals 45347

Warren L J 1975a Trans. IMM 84 C99-104

Warren L J 1975b J. Colloid Interface Sci. 50307

Weisun W 1982 Tungsten: 1982, Proc. 2nd int. tungsten symp. (San Francisco, London: Mining Journal Books) pp. $64-70$

Zhaboev M N, Semochin G A, Blinor Yu I, Dzhamoev F M, Novikov V V and Tereshchenko S V 1987 Tsvetn. Met. 198792 